UNIVERSIDADE DE SÃO PAULO

DEPARTAMENTO DE CIÊNCIA POLÍTICA

JAQUELINE PORTO ZULINI

Partidos, facções e comportamento parlamentar na democracia de 46 
JAQUELINE PORTO ZULINI

\section{Partidos, facções e comportamento parlamentar na democracia de 46}

Dissertação apresentada à Faculdade de Filosofia, Ciências e Letras da Universidade de São Paulo para a obtenção do título de Mestre em Ciência Política.

Orientador: Prof. Dr. Paolo Ricci.

VERSÃO CORRIGIDA

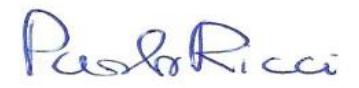

De acordo com a revisão

São Paulo 
Nome: ZULINI, Jaqueline Porto.

Título: Partidos, facções e comportamento parlamentar na democracia de 46.

Dissertação apresentada à Faculdade de Filosofia, Ciências e Letras da Universidade de São Paulo para a obtenção do título de Mestre em Ciência Política.

Orientador: Prof. Dr. Paolo Ricci.

Aprovado em:

\section{Banca examinadora}

Prof. Dr.:

Instituição:

Julgamento:

Assinatura:

Prof. Dr.:

Instituição:

Julgamento:

Assinatura:

Prof. Dr.:

Instituição:

Julgamento:

Assinatura: 
A meus pais, Edson e Maria, pelo apoio incondicional e carinho constante, que tornaram os dias de pesquisa e isolamento necessários bem mais fáceis. 


\section{Agradecimentos}

Depois de algumas horas buscando as palavras certas para reunir os devidos agradecimentos ao grupo de amigos e profissionais que estimulou a consecução desta pesquisa, seja direta, seja indiretamente, abandonei a preocupação semântica e entreguei o texto ao sabor do momento, marcado por grandes dívidas de gratidão. Sem exagero, a presente dissertação de mestrado talvez jamais se esboçasse não fosse a oportunidade privilegiada de estagiar, logo ao primeiro ano da graduação, no projeto Representação Política em São Paulo, conduzido pelo Centro de Estudos da Metrópole (CEM). Lara Mesquita depositou em mim o voto de confiança inicial para o meu ingresso, de fato, na academia e é personagem central neste path dependence que me conduziu dos estudos eleitorais aos legislativos. Sua generosidade e compreensão frente à minha maior afinidade com a arena parlamentar a motivariam consultar Andréa Freitas, a segunda personagem de destaque nesta história, sobre a possibilidade de me integrar ao grupo de estudos legislativos do Centro Brasileiro de Análise e Planejamento (CEBRAP).

Andréa não apenas compartilharia o seu conhecimento comigo, mas reuniria uma equipe de trabalho dedicada, cuja convivência estimo gozar. Danilo Medeiros, Rafael Freitas e Samuel Moura trariam mais vida ao subsolo cebrapiano, não podendo ficar de fora desses créditos, tanto pela saudável companhia na Casa quanto pela consideração pessoal. Neste quadro, ainda se encaixa Maurício Izumi, que se revelou grande companheiro nas discussões de última hora sobre a relevância de alguns testes empíricos finais, endossados no transcurso da análise subseqüente.

Referência intelectual para todos nós, o professor Fernando Limongi me orientou na fase inicial dessa investigação, antes de seguir para Yale. Registro a minha satisfação em poder ter a honra de contar com os seus comentários novamente, quando o texto caminhava 
para a conclusão. Suas idéias, como sempre, foram demasiado incentivadoras. Não aproveitálas da melhor forma é culpa exclusivamente minha.

Mestre e amigo, o professor Paolo Ricci me assumiu com total dedicação. Sempre disposto a ajudar no enfrentamento das dificuldades que se sucederam ao longo do presente estudo, habilmente encontrou racionalidade nas minhas idéias por vezes confusas, tecendo as oportunas sugestões que dariam real consistência ao exame aqui aventado. Agradeço pelas estimulantes discussões que tivemos, o constante incentivo de suas palavras e o zelo da sua leitura crítica e perspicaz, responsáveis pelo aperfeiçoamento da exposição oferecida a seguir. Novamente, todos os problemas restantes decorrem unicamente das minhas limitações.

À compreensão da minha família, um destaque especial. Antes de tudo, o meu empenho foi endereçado a vocês, que tanto amo. Espero que os resultados exibidos nas próximas páginas justifiquem a distância e as noites passadas a fio na frente do computador, enquanto tanto desejávamos estar juntos.

Por fim, deixo o meu agradecimento à Fundação de Amparo e Pesquisa do Estado de São Paulo (Fapesp) em função da concessão da bolsa de mestrado e pelo apoio financeiro para a realização desta pesquisa. 
Politics is about winners and losers, influence and coercion, exchange and bargaining, coalitions and factions, conflict and compromise. All these topics involve individuals and groups tied together in complex relationships that defy easy disaggregation and reaggregation.

(Huckfeldt \& Sprague) 
ZULINI, J. P. Partidos, facções e comportamento parlamentar na democracia de 46. 2011. 161 p. Dissertação de mestrado - Faculdade de Filosofia, Letras e Ciências Humanas, Universidade de São Paulo, São Paulo.

\section{RESUMO}

A literatura é pródiga em apontar o facciosismo como a norma do sistema partidário vigente à democracia de 46. Em função das constantes cisões verificadas no interior das legendas, a coalizão de apoio ao Executivo no parlamento seria predominantemente concebida ad hoc. O objetivo deste trabalho foi investigar a procedência da referida tese, avaliando o comportamento dos legisladores nas votações realizadas na Câmara dos Deputados entre 1946 e 1964. As informações reunidas no estudo permitem contestar a interpretação usual, comprovando ser incomum a base governista precisar de auxílio externo para assegurar a passagem da própria agenda de trabalho. Somente nas gestões de Getúlio Vargas e Juscelino Kubistchek as contribuições de membros de oposição se fizeram capitais para a aprovação dos programas do governo. Ainda assim, seriam as metas varguistas as mais dependentes deste tipo de subsídio. No quadro geral, o êxito administrativo das presidências decorreria do uso estratégico da verificação de quorum, um procedimento regimental que permitia tanto à situação quanto as demais legendas visualizarem a divisão de forças no plenário, minimizando o efeito-informação de Riker (1962). Desta forma, o governo pôde calcular a melhor estratégia política capaz de lhe certificar a vitória em plenário, independentemente da ajuda dos opositores.

Palavras-chave: democracia de 46, facções, partidos, maioria legislativa, coalizões partidárias. 
ZULINI, J. P. Parties, factions, and voting behavior in the Brazilian Second Republic (19461964). 2011. 161 p. Dissertação de mestrado - Faculdade de Filosofia, Letras e Ciências Humanas, Universidade de São Paulo, São Paulo.

\begin{abstract}
The literature tells us that factionalism was the norm in the party system of the Brazil's Second Republic (1946-1964). As a result of constant factions within parties, presidential coalitions in the legislature were primarily constructed ad hoc. The objective of this study was to investigate the origin of this argument by analyzing the behavior of legislators on roll call votes in the Chamber of Deputies between 1946 and 1964. The data used in this investigation challenge the conventional wisdom by showing that it was unusual for governing coalitions to need outside help to ensure the adoption of their agendas. Only in the administrations of Getúlio Vargas (1951-1954) and Juscelino Kubistchek (1956-1960) was the support of members of the opposition essential to the approval of government programs, with Vargas' agenda being most dependent on this type of support. In general, presidents' success arose from the strategic use of verification of quorum, a procedural rule that allowed both the government and the opposition to visualize the division of the forces in the legislature, minimizing Riker's (1962) information effect. Thus, the government could calculate the best political strategy able to ensure victory, independent of opposition support.
\end{abstract}

Keywords: Brazilian Second Republic, party factions, parties, legislative majority, presidential coalitions. 


\section{Lista de figuras}

Figura 1.1 - Processo de votação

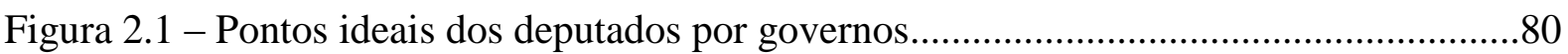

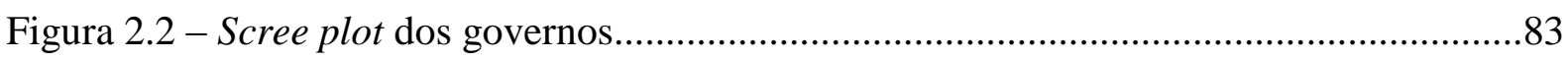

\section{Lista de gráficos}

Gráfico 2.1 - Autoria dos pedidos de verificação concedidos, por grupo parlamentar (19461964)

Gráfico 2.2 - Autoria dos pedidos de verificação concedidos, por grupo parlamentar, segundo a origem das matérias em votação (1946-1964) .73

Gráfico 2.3 - Origens das votações nominais (1946-1964)...................................................75

Gráfico 2.4 - Saldo das verificações de quorum (1946-1964)................................................76

Gráfico 2.5 - Influência da conduta do presidente da Câmara no processo decisório (19461964)

Gráfico 3.1 - Distribuição das verificações de votação, por anos do mandato presidencial (1946-1964)

Gráfico 3.2 - Contribuição média de setores da oposição em votações válidas e não-unânimes sobre matérias iniciadas pelo Executivo, vitorioso com a ajuda da oposição. 105

Gráfico 3.3 - Contribuição média dos udenistas em votações válidas e não-unânimes sobre matérias iniciadas por governistas, vitoriosos com a ajuda da oposição 106 


\section{Lista de Tabelas}

Tabela 1.1 - Índice de Rice médio, segundo a origem da matéria em votação.

Tabela 2.1 - Distribuição das verificações de votação, por coalizões (1946-

1964)

Tabela 3.1 - Vitórias e derrotas do governo, por coalizão, em votações nominais (1946-

1964)

Tabela 3.2 - Tipos de vitória do governo, por coalizão, em votações nominais (1946-

Tabela 3.3 - Tipos de vitória do governo, por coalizão, segundo a escolha procedimental, em votações nominais de matérias iniciadas pelo Executivo (1946-1964) .94

Tabela 3.4 - Tipos de vitória do governo, por coalizão, segundo a escolha procedimental, em votações nominais de matérias iniciadas por governistas (1946-1964).

Tabela 3.5 - Vitórias e derrotas do governo, por coalizão, em votações nominais válidas e

não-unânimes (1946-1964).

Tabela 3.6 - Tipos de vitória do governo, por coalizão, em votações válidas e não-unânimes

Tabela 3.7 - Número de assentos na Câmara dos Deputados ocupados por parlamentares governistas em Vargas e JK

Tabela 3.8 - Distribuição das preferências entre os partidos que compõem a coalizão nas 17 votações em que as iniciativas do Executivo só se fizeram aprovadas graças ao apoio da oposição.

Tabela 3.9 - Relação de udenistas que mais votaram com o governo em Vargas II. 107

Tabela 3.10 - Exxito do governo em matérias iniciadas pelo Executivo ao longo do mandato presidencial (1946-1964). 108 
Tabela 3.11 - Êxito do governo em matérias iniciadas por governistas ao longo do mandato presidencial (1946-1964)

Tabela 3.12 - Verificações de votação concedidas segundo o teor das medidas em exame, por coalizão (1946-1964) 120

Tabela 3.13 - Resultado das verificações de votação em proposições de políticas paroquialistas (1946-1964)

Tabela 3.14 - Vitórias e derrotas do governo em medidas locais (1946-1964) 122

Tabela 3.15 - Tipos de vitórias do governo, por coalizão, em medidas locais (1946-1964)..122

\section{Lista de Anexos}

ANEXO A - Coalizões (1946-1964). 133

ANEXO B - Alterações regimentais no processo de votação

ANEXO C - Verificação de votação precedida de renovação da votação simbólica

ANEXO D - Escolhas do presidente sobre o rumo de votações sem quorum......

ANEXO E - Autoria dos pedidos de verificação concedidos, por coalizão (1946-1964)

ANEXO F - Distribuição dos pedidos de verificação de votação, por partidos (1946-

1964)

ANEXO G - Autoria dos pedidos de verificação concedidos, por coalizão, segundo a origem das matérias em votação (1946-1964).

ANEXO H - Origens das votações nominais, por coalizões (1946-1964)

ANEXO I - Saldo das verificações de quorum, por coalizões (1946-1964)

ANEXO J - Influência da conduta do presidente da Câmara no processo decisório (1946-

ANEXO K - Resultados estatísticos dos modelos espaciais, por coalizões.

ANEXO L - Temas caros à agenda governamental, objetos de verificação de votação. 
ANEXO M - Contribuição decisiva dos udenistas nas 17 votações válidas e não- unânimes de iniciativas do Executivo.

Anexo N - Distribuição das preferências entre os partidos que compõem a coalizão nas 89 votações em que as iniciativas dos governistas só se fizeram aprovadas graças ao apoio da oposição

ANEXO O - Contribuição decisiva dos udenistas nas 89 votações válidas e não-unânimes iniciadas pelo governo. 


\section{SUMÁRIO}

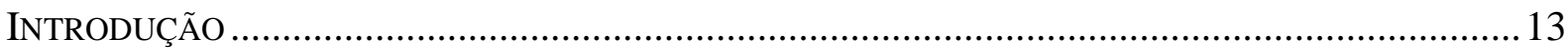

CAPÍTULO 1 - OS CUSTOS DA GOVERNABILIDADE NO PRÉ-64: A VISÃO CONVENCIONAL.............21

1.1. Características gerais do sistema partidário (1946-64) ..........................................22

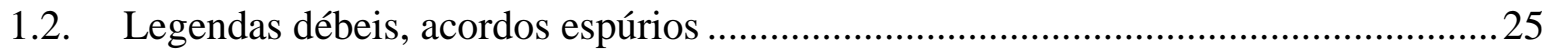

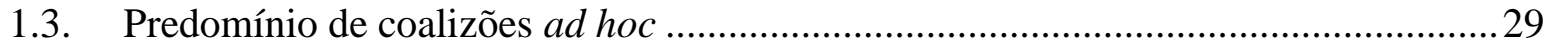

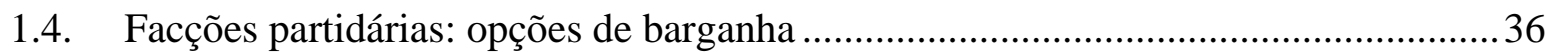

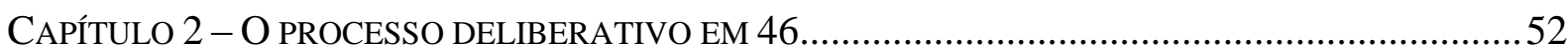

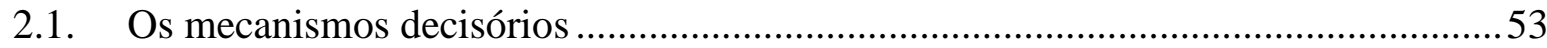

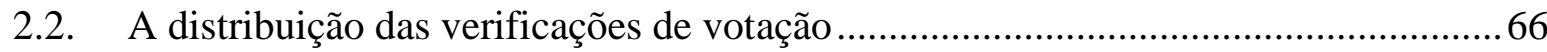

2.2.1. Uso estratégico do pedido de verificação ........................................................... 74

2.2.2. O padrão espacial da formação de preferências na democracia populista ..........78

CAPÍTULO 3 - FACCIOSISMO E CAPACIDADE DECISÓRIA NA REPÚBLICA DE 46 .......................... 85

3.1. Vitórias e derrotas do governo na Câmara dos Deputados ..................................... 88

3.1.1. Votações críticas e facções partidárias ................................................................. 99

3.2. A construção de maiorias em políticas de efeito circunscrito .................................110

3.2.1. O debate regionalista em plenário .................................................................... 111

3.2.2. As votações efetivas de medidas paroquiais............................................... 119

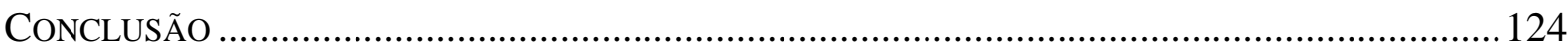

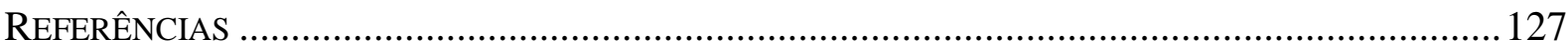

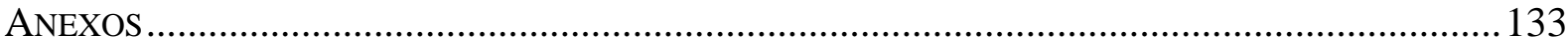




\section{INTRODUÇÃO}

Partidos clientelistas, fisiologistas, debilmente organizados. Políticos populistas, individualistas, de franca tendência apartidária. Eis o pano de fundo sob o qual repousaria a ordem democrática instituída no Brasil a partir de 1945, que reativaria as legendas como canais de representação de interesses e participação política, embora a estrutura partidária, tanto aos olhos dos atores como aos dos analistas, não se revelasse mais do que um arranjo político superficial, propenso à instabilidade crônica.

Não faltariam elementos para justificar o pessimismo perante as instituições representativas. A legitimidade do sistema partidário era contestada pelas próprias lideranças políticas, que não raro se colocavam acima das siglas, a exemplo das propostas de atuação independente levadas a público por Getúlio Vargas e Jânio Quadros em suas respectivas passagens pela presidência da República no período (D’ARAÚJO, 1992; BENEVIDES, 1981b; SKDIMORE, 1975). Personalista, a ação dos ex-presidentes se mostrava condizente, inclusive, com a impressão, bastante disseminada, da identificação do eleitorado com figuras específicas, em detrimento de linhas doutrinárias bem delimitadas, de existência duvidosa (OLIVEIRA, 1973).

O ceticismo em torno da viabilidade de um governo partidário era acrescido pela reconhecida dificuldade enfrentada pelas legendas em harmonizar as várias forças antagônicas reunidas sob seus quadros, que se sujeitariam a dividir uma mesma filiação política em função de fins meramente eleitorais, dada a necessidade criada por imposição legal de tal registro como condição elementar à disputa de cargos eletivos. Emblemática, a União Democrática Nacional (UDN), o maior partido de oposição do pré-64, seria a melhor reconstituição desse arriscado cálculo político. 
Ampla frente de combate ao Estado Novo, a UDN "surge como um movimento agregador das mais variadas tendências e raízes históricas", onde "adversários de tempos imperiais, velhos inimigos, desafetos jurados, reúnem-se com a finalidade única de apressar a queda de Vargas e suprimir seu regime", para se lançarem candidatos ao poder com a reconquista das liberdades democráticas (BENEVIDES, 1981a, p. 28-29). Não tardaria, porém, para que as dissidências emergissem, com a saída de alguns militantes que formalizariam seu afastamento da legenda a fim de organizar outras agremiações a nível estadual - como os "perrepistas" Arthur Bernardes, Lino Machado e Eurico Souza Leão (fundadores do Partido Republicano [PR] mineiro, maranhense e pernambucano, nesta ordem), Adhemar de Barros (idealizador do Partido Republicano Progressista [PRP] paulista, que passaria a se chamar Partido Social Progressista [PSP] um ano depois) e Raul Pilla (líder do Partido Libertador [PL] gaúcho) - ou mesmo a nível federal, como João Mangabeira (organizador da Esquerda Democrática [ED], mais tarde conhecida como Partido Socialista Brasileiro [PSB]), para citar alguns (Ibid., p. 47-49).

Tantas deserções não significariam o alcance da concórdia. As filiações remanescentes seriam responsáveis pelas constantes cisões internas a comprometer a coesão da sigla, que para muitos analistas teria a eterna conotação de um movimento, e nunca de um partido político. Dentre as alas mais famosas, destacam-se: 1) a Banda de Música, assim conhecida devido ao barulho que seus membros faziam no plenário com sua oratória inflamada dirigida contra o governo; 2) os Chapas-Brancas, vertente formada por parlamentares, predominantemente nordestinos, sensíveis às possibilidades de aproximação com o governo e 3) a Bossa Nova, grupo ratificado na primeira convenção udenista ocorrida após a vitória de Jânio Quadros que se opunha à Banda de Música ao defender o apoio aos projetos reformistas do governo, considerados nacionalistas (Ibid., p. 47-49). Todavia, seria possível ainda apontar 
ramificações menores, de cunho ideológico, além das marcantes diferenciações regionais (BENEVIDES, 1981a, p. 47-49).

Menos estudado, o Partido Trabalhista Brasileiro (PTB) não seria menos polêmico. A legenda que conduziu Vargas de volta ao poder, desta vez por meios constitucionais, amargaria o descaso do presidente, que a relegou a um segundo plano (D’ARAÚJO, 1992; SKDIMORE, 1975). Almejando participação efetiva, os trabalhistas estariam em constante convulsão, o que talvez só tenha contribuído para aumentar a desatenção de seu fundador diante das ambições dos seus correligionários pela tão desejada fatia no poder (Ibid., 1992, p. 121).

À época da administração Goulart, seria possível mesmo identificar três alas trabalhistas de contestação ao chefe do Executivo, com ramificações na Câmara dos Deputados, a saber: I) uma vertente "radical", representada por Almino Afonso, Miguel Arrais, Leonel Brizola e Neiva Moreira, entre outros; II) uma corrente "fisiológica", encampada por Parsifal Barroso, Ivete Vargas, Clemens Sampaio, Batista Ramos e Fernando Nóbrega e III) uma ala dos "teóricos", que congregava nomes como Fernando Ferrari, Santiago Dantas e Lúcio Bittencourt, para citar alguns (BENEVIDES, 1979, p. 131).

Ícone do adhemarismo, o Partido Socialista Progressista (PSP) se fazia tão heterogêneo que sequer era reconhecido como agremiação política pela maioria dos cientistas sociais até meados da década de 1960, sobretudo por destoar do modelo preferido pelos intelectuais, sensíveis ao padrão europeu de organização partidária (SAMPAIO, 1982, p. 13). De expressão significativa apenas no âmbito paulista, a baixa disciplina e a diminuta coesão da legenda a nível federal autorizava, na visão dos analistas, sua leitura como um movimento, produto que era do fenômeno - igualmente pensado como "pré-político" - liderado por Adhemar de Barros. 
Não se pode negar o poder do ex-interventor de São Paulo para os rumos da sigla, que passou à história como “o símbolo do partido de um homem só” (SAMPAIO, 1982, p. 128). A centralização decisória nas mãos de Adhemar ao longo de todo o pré-64 retrata a manutenção da unidade partidária sob o mesmo prisma que marcou o advento da legenda: a ampliação de forças no estado. Afinal, a motivação da fusão do PRP com o Partido Popular Sindicalista (PPS), de Miguel Reale e Marrey Jr., e o Partido Agrário Nacional (PAN), liderado por Mário Rolim Teles, compondo o PSP, residia nas eleições estaduais de 1947, nas quais a mais nova agremiação paulista sairia vencedora com Barros (Ibid., p. 51). A penetração nas demais unidades federativas se mostrava residual, uma vez que sempre se fazia em função de cisões dos partidos dominantes em cada região (Ibid., p. 127). Como tal, a legenda se via constantemente à mercê das injunções na política local, que catalisava a já presente diversidade ideológica observada em seus quadros.

Até mesmo a maior sigla do período teria convivido com contendas internas consideráveis, sucumbindo quando já não se mostrava mais capaz de equalizá-las - e levando consigo, assim, a estabilidade do regime. Essa é a tese de Hippólito (1985), que aponta o Partido Social Democrático (PSD) como o avalista do regime de 1946, posição prejudicada por causa do crescente radicalismo da Ala Moça ou reformistas (grupo renovador, estreitamente vinculado à candidatura e ao governo de Juscelino e disposto a revitalizar os métodos do PSD) frente aos ditames das raposas (como eram conhecidos os pessedistas tradicionais, contrários as idéias trazidas pelos moços), a ponto de deslocar a legenda da sua posição original no eixo político, de centro, considerada pela autora elemento basilar para a manutenção do sistema então em voga (HIPPÓLITO, 1985, p. 141).

O mais interessante, porém, é que a despeito da suposta razão definidora de representantes com inclinações tão díspares se manterem filiados às mesmas agremiações - a disputa de pleitos -, o cenário pré-escrutínio se revelaria mais favorável a divergências 
intrapartidárias. O imperativo eleitoral não atenuaria as cisões ideológicas, que ficariam mais patentes no contexto sucessório.

De fato, a literatura é pródiga em apontar como as articulações de candidaturas evidenciavam as divisões internas e o regionalismo político, que estremeciam a unidade dos partidos da época, inclusive a pessedista. A boicotada campanha de Cristiano Machado (PSD/MG) à sucessão de Eurico Gaspar Dutra no Executivo federal, que sequer encontrou apoio significativo dentro do próprio partido e o atrevido oferecimento de Etelvino Lins (PSD/MG) para as eleições presidenciais de 1955, indicado pelas seções pessedistas contrárias a chapa JK-Jango, lançada oficialmente pelo Diretório Nacional do partido - a saber: Pernambuco, Santa Catarina, Rio Grande do Sul e em parte, Minas Gerais -, constituem os casos mais expoentes dentre os muitos episódios de realinhamentos e rompimentos ocorridos no interior das legendas em função do calendário eleitoral (D’ARAÚJO, 1992; HIPPÓLITO, 1985; BENEVIDES, 1979; SKIDMORE, 1975).

Independentemente dessas inconstâncias no quadro partidário, e por maiores as pretensões individualistas dos presidentes sufragados no período, há relativo consenso em torno do papel das legendas para a manutenção da ordem democrática (D’ARAÚJO, 1992; HIPPÓLITO, 1985), em que pese a necessidade dos governos precisarem compor coalizões no Congresso, embora elas normalmente correspondessem a acordos concebidos ad hoc (D’ARAÚJO, 1992; SKIDMORE, 1975).

Freqüentes, os assédios de Getúlio à UDN retratam não apenas uma tentativa de fortalecer o apoio da classe média urbana ao presidente, mas corrobora a validade da agência dos partidos políticos no processo de tomada de decisão (D’ARAÚJO, 1992). Na ausência de uma coalizão estável no parlamento, vários dos projetos do interesse de Vargas teriam sido aprovados "graças ao apoio da UDN, partido que, na maioria das situações, assumia, individualmente, uma posição de veto em relação ao Governo" (Ibid., p. 37). 
A própria estabilidade gozada pela administração Kubitschek também decorreria, em grande parte, da captação de votos udenistas, vitais para a aprovação da tão aclamada agenda desenvolvimentista. Considerado um caso atípico quando se trata da tônica política de 46-64, o governo JK fundaria o reconhecido sucesso sob o apoio parlamentar de uma aliança que não se restringira à convencional união PSD-PTB, "o que não teria sido suficiente", mas que incluiria ainda "uma facção da UDN, sempre que aspectos fundamentais do Plano de Metas estivessem em tela de juízo" (SANTOS, 2003, p. 277, grifo meu).

Com efeito, existem indícios que apontam a colaboração dos udenistas em todas as administrações anteriores à posse de Jânio Quadros (Ibid, cap. X). Também há dados sobre uma postura colaboracionista do PSP nos anos JK, mesmo a legenda não compondo oficialmente a base governista (CARVALHO, 1977). Todavia, inexiste investigação que tenha realmente testado o facciosismo no período, apesar de sua existência ser dada como certa.

Diminutas, as pesquisas sobre a possibilidade de apreensão da concreta atuação indisciplinada dos parlamentares frente às suas filiações partidárias, no âmbito legislativo, limitaram-se apenas à análise das legendas de oposição e, o mais desanimador, abordaram as siglas como atores unitários, mesmo observando a vigência de um aparente padrão sedicioso, indicado pela proporção de votos desobedientes à posição normalmente esperada a ser seguida pelas bancadas nas votações nominais (SANTOS, 2003; AMORIM NETO, SANTOS, 2001; CARVALHO, 1977).

À luz da epígrafe que abre a exposição, sinalizo o objetivo deste trabalho, dedicado à compreensão do funcionamento das coalizões de apoio ao governo bem como à interação entre partidos e deputados durante a democracia populista (1945-1964). O intuito é apreender a lógica daquele sistema político-partidário investigando como a relação entre presidente e maioria se dava a partir das votações de matérias de interesse do governo e, por extensão, 
verificar a procedência da tese do facciosismo para o período. A existência de subdivisões dentro dos maiores partidos de então (PSD, UDN, PTB e PSP) será colocada à prova a partir do exame do comportamento das legendas nas deliberações ocorridas no plenário da Câmara dos Deputados.

Em caráter complementar, a intenção é vislumbrar a possibilidade de delimitar nomes e grupos que negociem efetivamente seus votos, em dissidência com a orientação majoritária encerrada por suas respectivas bancadas oficiais, bem como a eficiência e a continuidade temporal desses potenciais compromissos assumidos - uma das noções inerentes à própria definição de facção -, tornando a confrontação de opções individuais complementar aos exames dos dados agregados.

No primeiro capítulo, mobilizo a avaliação da literatura sobre o sistema político característico do pré-64. Demonstro como a interpretação dominante, de marcado cunho pessimista, explora a combinação do populismo com os agravantes das relações tradicionais de poder (tais como o clientelismo e o empreguismo), para justificar o regionalismo e o fisiologismo das legendas, condicionando a fraqueza das instituições representativas como veículos de mobilização e agência efetiva e, por extensão, qualificando a tendência de governos apartidários na democracia de 1946. Enfatizo o consenso relativo à conotação facciosa dos partidos, recuperando as tentativas de mensurar a coesão interna das siglas e a insuficiência dos testes até então realizados para uma afirmação definitiva das facções como regra no período.

Uma proposta alternativa de avaliação do facciosismo é iniciada no segundo capítulo, onde demonstro como um dispositivo regimental inexistente na atualidade - a verificação de votação por bancadas - facultou ao governo e à própria oposição o controle, em certa medida, do rumo das deliberações na Casa, pela observação dos seus pares em resultados parciais, atenuando o potencial desconhecimento de suas exatas forças relativas no plenário. A 
checagem do resultado da deliberação anunciado pela presidente da sessão legislativa permitia abrandar o efeito-informação de Riker (1962), que diz respeito à dificuldade do Executivo estimar com precisão o real tamanho de sua base de apoio no Congresso. Por via regimental, se fazia possível acionar tanto a mobilização no seio do governo e no interior da oposição como entre dissidências intrapartidárias para a conformação de forças ad hoc. Todavia, essas últimas não se revelariam tão comuns como se apregoa.

O exame do comportamento do plenário durante as votações de proposições do interesse dos governos que então se sucedem não permite apontar correntes claramente definidas agindo na Câmara. Tampouco, a constante contribuição decisiva da oposição na aprovação das agendas políticas das administrações presidenciais no pré-64, à exceção de uma coalizão varguista. É o que o terceiro capítulo sinaliza, através da crítica as deliberações então registradas. Não há indícios aparentes de dissidências intrapartidárias constantes no seio da coalizão de apoio ao governo, da mesma forma que os votos da oposição coincidentes com os interesses da base governista são de autoria flutuante, sendo difícil afiançar a hipótese de apoio regular de setores oposicionistas à situação. Até mesmo se controlando os resultados políticos em função da temática regionalista, que deveria justamente ser o pivô das divisões ideológicas sobre uma mesma legenda, nos moldes da visão usual, não se observa qualquer alteração significativa no padrão deliberativo do período, demasiado diverso do relatado pelos estudos até então disponíveis.

A leitura dos dados sugere, antes, que os especialistas têm sobredimensionado o efeito do faccionalismo sobre a capacidade decisória e os saldos políticos delineados no Legislativo Federal à República de 46. Em geral, a coalizão de apoio ao presidente no parlamento conseguia administrar, sozinha, o alcance das metas que realmente estimava. Como veremos, não faltariam armas para lhe assegurar a coação dos próprios quadros partidários, minimizando as chances de depender de auxílios externos para atingir os objetivos almejados. 


\section{CAPÍtulo 1 - Os custos da governabilidade no pré-64: a visão convencional}

A literatura é unânime em apontar a instabilidade crônica como a norma da primeira experiência democrática brasileira (SANTOS, 2003; CARVALHO, 1977; SOUZA, 1976). Realmente, a cronologia do período retrata uma série de convulsões políticas que assolaram o regime de 46 até o início do interregno autoritário. Somados, o suicídio do presidente em exercício, em agosto de 1954; a conseqüente cisão dos militares com o 'golpe preventivo' do general Lott, a novembro do ano seguinte; a renúncia do chefe do Executivo, em 1961; a condenação do parlamentarismo pelo plebiscito realizado no início de 1963 e o desfecho ditatorial de 1964 delinearam novo quadro sensível à aplicação de uma das teorias desenvolvimentistas mais perenes - a saber, a da incompatibilização entre crescimento econômico e estabilidade política.

De fato, há persuasivas demonstrações sobre o potencial para o conflito suscitado a partir da repercussão do desenvolvimento no interesse das classes sociais (FERNANDES, 1967; HUNGTINTON, 1972). Não por acaso, a associação entre a sensação de crise iminente, paradigma da época, e a dinâmica socioeconômica das décadas de 50 e 60 constituiu, por muito tempo, o segundo objeto de consenso entre os trabalhos dedicados à República de 46. Sejam investigações dirigidas à arena eleitoral, sejam discussões voltadas ao foro parlamentar, asserções sobre os impactos da urbanização crescente e as decorrentes mudanças estruturais na polis, então em processo, frente à manutenção do próprio arcabouço institucional vigente naquele momento ocupam, com maior ou menor destaque, espaço certo nos modelos explicativos. A dificuldade de incorporação das demandas do novo eleitorado é duplamente recuperada tanto enquanto causa de fragmentação partidária (CARVALHO, 1958), quanto como responsável pela flutuação e mesmo desestruturação do sistema de partidos (PETERSEN, 1962; SCHWARTZMAN, 1971). Os constantes episódios de impasse decisório 
no Parlamento apenas refletiriam o caráter artificial das legendas, incapazes de solucionar seus problemas de coesão interna no mesmo ritmo seguido pela modernização da base social do país, marcadamente acelerada nos 'anos dourados'(LAFER, 1970, 2002).

Parciais, o amadurecimento e a consolidação das siglas teriam sido limitados por fatores culturais, dada a prolongada sobrevivência das relações tradicionais de poder para muito além dos muros rompidos do Estado Novo. Resquícios de clientelismo e empreguismo justificariam o apelo regionalista bem como o fisiologismo das legendas, condicionando a fraqueza das instituições representativas como veículos de mobilização e agência efetiva e, por extensão, moldando a tendência apartidária dos governos formados durante a democracia de 1946 (LEAL, 1976 [1949]; SAMPAIO, 1982).

\subsection{Características gerais do sistema partidário (1946-64)}

O receio dos analistas diante da temida propensão clientelista do quadro partidário no pré-64 remonta ao desmanche estado-novista, quando se temia que a sobrevivência de padrões políticos tradicionais comprometesse o funcionamento efetivo da democracia recémconquistada (SAMPAIO, 1982). Emblemático, o clássico trabalho de Victor Nunes Leal (1976 [1949]) sobre o coronelismo ilustra muito bem os termos do debate, apontando o regionalismo e a privatização local do poder público pela ação dos coronéis como entraves estruturais a corromper as práticas democráticas nacionais asseguradas constitucionalmente (Ibid., p. 21).

Uma análise retrospectiva, que se tornaria a principal interpretação sobre o período que se inicia com o advento da ditadura varguista estendendo-se até o golpe de 1964, sinalizaria a procedência de tal receio. Souza (1976) demonstraria como a interferência da estrutura estatal anterior à restauração liberal condicionou a formação das legendas e o 
comportamento do sistema partidário como um todo. A seu ver, o desmantelamento da velha ordem não teria passado de uma "modernização conservadora", já que não se alterou a configuração preexistente, inclusive em relação ao poder das elites dirigentes, simplesmente transferidas das interventorias estado-novistas para os quadros do principal partido da democracia de 1946 - o Partido Social Democrático (PSD) -, enquanto os interventores desalojados do poder por designação central e todos os demais insatisfeitos com a ditadura se reuniriam, com a restauração liberal, sobretudo na União Democrática Nacional (UDN).

Neste sentido, o estímulo à política clientelista prevaleceria, em detrimento da institucionalização das legendas, condenada pela interferência da estrutura estatal centralizada no processo de formação do sistema partidário (SOUZA, 1976, p. 36) ${ }^{1}$. De fato, alguns estudos associariam a duração da nossa primeira experiência democrática ao poder gozado pelos pessedistas a nível local, garantindo a adesão dos "coronéis" ao governo bem como o enquadramento da massa eleitoral, diretamente controladas pelos chefes locais (BENEVIDES, 1979; CAMARGO, 1973).

Em estudo de caso sobre o PSD, Oliveira (1973) enfatiza a relevância da flexibilidade do Diretório Nacional (DN), órgão máximo da legenda em termos institucionais, diante das peculiaridades estaduais e locais para a solução dos vários conflitos internos vivenciados pela agremiação entre 1946 e 1964, intervindo sempre que se fizesse necessário para amenizar os choques e reconciliar as correntes em dissidência. Segundo a autora, vários parlamentares cuidavam da atualização de um fichário com informações sobre seus eleitores - que eram vinculados aos políticos, e não à legenda -, podendo mesmo especificar verbas no orçamento federal e estadual para seus redutos eleitorais. Daí a maleabilidade do DN, que preferia restringir sua "mão pesada" ao âmbito nacional, garantindo maior margem de manobra às

\footnotetext{
${ }^{1}$ Jaguaribe (1962) também insiste no predomínio de uma tendência clientelística nos dois principais partidos da época - PSD e UDN.
} 
seções regionais, a se indispor com os interesses locais - a esfera que realmente coordenava a oferta de votos aos pessedistas.

Com efeito, Skdimore afirma que a própria vitória de Getúlio nas eleições presidenciais de 1950 se deva, em grande parte, à sua aliança com as velhas forças políticas, "representadas pelos políticos de estilo tradicional - especialmente do PSD - para quem a política era menos uma questão de diretrizes e princípios que de poder e empreguismo", tal a forma como os pessedistas encarariam a vida pública: "um processo para satisfazer aos seus ‘clientes', geralmente os proprietários da estrutura social rural” (SKDIMORE, 1975, p. 106)². Considerando-se que a UDN se revelou capaz de disputar eleições com o PSD em "quase todos os municípios de todos os estados" no pré-64 (SOARES, 1973), é válido supor que, tal como seu rival, a praxe da legenda também tivesse clara conotação clientelística, sendo muito provável encerrar a tão propalada inclinação fisiologista das siglas à época, inclusive em plenário. Neste caso, as tentativas presidenciais em trazer os udenistas para o governo poderiam se revelar razoavelmente custosas, da mesma forma que manter a própria base de apoio exigiria uma relativa habilidade de negociação.

Afinal, os próprios trabalhistas, que estiveram aliados formalmente ao Executivo por quase toda a democracia populista, tampouco se revelariam menos propensos à política de clientela, sobretudo a seção paulista, minada "pelo empreguismo e pelo tráfico de influências", conhecido "na linguagem jornalística" como "fisiologismo", levando o partido a se acomodar "nos quadros de um partido clientelístico mais do que em um partido de massas" (CARDOSO, 1978, p. 46).

\footnotetext{
${ }^{2}$ A outra parte elementar para o sucesso do ex-ditador constituiria na sua aproximação com as "novas forças políticas do país", "representadas pelos políticos populistas, que haviam demonstrado capacidade de obter os votos das massas em crescimento inclusive a classe operária e a baixa classe média - nas cidades maiores". Ademar de Barros seria o principal beneficiário dessa política de novo estilo, e mesmo Vargas assumiria esse papel, "nos seus esforços para construir o PTB", de modo que a "formidável aliança" encampada por Getúlio repousaria "num casamento de conveniência", isto é, "no PSP de Ademar (de crucial importância em São Paulo), no PTB, e no PSD, onde a lealdade deste último fosse negociável" (SKIDMORE, 1969, p. 106-107). Desconheço leitura mais emblemática da visão predominante - e marcadamente pessimista - sobre o sistema partidário da época: clientelista, fisiologista e ainda mais enfraquecido com o advento de líderes populistas.
} 
Retrato idêntico caberia ao PSP, legenda cujo controle da direção no nível do município significava, "para os chefes políticos locais, o monopólio do acesso aos favores governamentais - e estes abrangiam desde o atendimento a pedidos de nomeação de funcionários até a alocação de benefícios para o município” (SAMPAIO, 1982, p. 136). Respaldado no adhemarismo, o pessepismo teria se revelado um "mecanismo de compatibilização" entre "a estrutura sócio-econômica de São Paulo, indiscutivelmente mais avançada e complexa e [...] seus padrões políticos naquele período, ao que tudo indica não menos imersos na cooptação e no clientelismo, do que os de estados mais pobres" (Ibid., p. $15)$.

\subsection{Legendas débeis, acordos espúrios}

Definitivamente, o padrão europeu de organização partidária não se aplicava ao Brasil de 46-64. Pelo relato da literatura voltada ao tema - abordagem predominante até os anos $1980^{3}$-, as relações políticas articuladas no seio das legendas revelavam estruturas débeis, de coesão questionável e fluida disciplina. Sob pressão de movimentos exógenos, o sistema partidário responderia com aproximações espúrias e contraditórias, tudo para se evitar a dissolução institucional, aparentemente em constante iminência.

Dentre as forças externas que invariavelmente ressoavam na conduta das agremiações que deveriam, em tese, dar suporte ao regime então em voga, as manifestações de repúdio e propaganda a Getúlio têm primazia. O temor relativo a um possível retorno ao poder daquele líder odiado por muitos, mas aclamado pelo povo, acompanhado de nova suspensão das liberdades democráticas, não estaria apenas na razão de fundação da União Democrática Nacional (UDN) em abril de 1945, que surge como uma ampla frente de oposição, reunindo

\footnotetext{
${ }^{3}$ Mais exatamente, Benevides (1979, 1981a, 1981b), Leal (1976), Lippi (1973), Sampaio (1982) e Souza (1976).
} 
um grupo bastante heterogêneo, com um único objetivo em comum - o antigetulismo. Justificaria, também, a própria aproximação dos udenistas à legenda organizada sob os auspícios do temido ditador a partir das interventorias criadas durante o Estado Novo - o Partido Social Democrático (PSD) -, com o qual comporiam uma "aliança conservadora" na primeira administração do período (o governo Dutra), mesmo ruminando tal associação (BENEVIDES, 1979, 1981a).

Com efeito, a aparente adesão espúria da UDN ao Acordo Interpartidário de $1948^{4}$, acertado entre os seus principais líderes com a cúpula pessedista visando à consolidação do regime recém-instaurado e a "pacificação nacional” representava um acurado cálculo político do maior partido de oposição, que vislumbrava uma forma de combater a extinção das suas chances de vir a se tornar governo. A despeito dessa consonância de forças soar como uma "heresia", senão mesmo como uma traição da oposição às suas próprias diretrizes, tornandose um dos exemplos do fisiologismo das siglas no pré-64 preferidos pelos analistas, há que se reconhecer o caráter estratégico por trás de sua concepção. Como pondera Benevides (1981a), não estava em jogo apenas um embargo ferrenho a Vargas, "sem dúvida um fortíssimo catalisador", mas a "oposição ao que ele, e não o General Dutra, poderia significar em termos de reformas sociais e econômicas e ampliação da participação política"

\footnotetext{
${ }^{4}$ Assinado no palácio do Catete a 22 de janeiro de 1948 pelos presidentes dos três partidos envolvidos: Nereu Ramos (PSD), José Américo de Almeida (UDN) e Artur Bernardes (PR), o acordo interpartidário "estabelecia 'bases de entendimento comum, entre si e com o governo da República', visando a três objetivos principais: 1) 'consolidar o regime e aperfeiçoar a sua prática', especialmente 'pelo estrito cumprimento da Constituição, como critério fundamental de toda a atividade pública'; 2) 'promover a elaboração e execução imediata de um plano econômico e financeiro, assumindo igualmente o compromisso de velar pelo equilíbrio orçamentário'; e 3) 'cumprir, o quanto antes, pela legislação complementar ou ordinária, os preceitos constitucionais de ordem econômica e social destinados a elevar o nível de vida do homem brasileiro'.

Os três partidos contavam, respectivamente, com 151, 77 e 7 (somando 235) dos 286 deputados federais. Assim, o acordo garantia a Dutra folgada maioria para a aprovação das matérias mais relevantes no parlamento. Além de cristalizar o consenso dos grupos políticos conservadores em torno do governo, oferecia a cada um dos dois grandes partidos (ao PR, caberia barganhar sua participação na composição, embora Artur Bernardes acalentasse sonhos de uma ressuscitada grandeza) a esperança de ver resolvida a seu favor - sob a égide de Dutra e das autoridades militares - a questão da sucessão presidencial, com a indicação de um candidato comum, e, assim, virtualmente imbatível. O acordo funcionou para dar a Dutra condições ímpares, em regime constitucional, de governar praticamente sem oposição parlamentar. Mas, como se veria depois, não funcionou para resolver justamente o problema que na verdade o motivara, o da sucessão presidencial" (CPDOC, Verbete Biográfico, Getúlio Vargas, grifos meus).
} 
(BENEVIDES, 1981a, p. 219, grifo da autora). Nesse sentido, “A UDN, através de seus porta-vozes mais realistas, já percebia, naquela época, que uma aliança PSD-PTB se revelaria imbatível, o que, aliás, o futuro próximo confirmaria" (Ibid., grifo meu).

Muito embora a conformação interpartidária, que incluía ainda o Partido Republicano (PR), tenha supostamente vingado em nível de governo, inexistindo oposição parlamentar significativa ao governo Dutra ${ }^{5}$, o acordo atestaria os primeiros sinais de fragilidade já em fins de 1949, diante da constatada dificuldade em se encontrar um candidato comum, de "coalizão nacional”, para o pleito de 1950 (BENEVIDES, 1981a) ${ }^{6}$. Estaria dada, assim, a largada para uma corrida em busca de apoio à agenda do governo, uma vez que a inviabilidade de uma coalizão "conservadora" poderia comprometer a capacidade decisória do sistema político. Começava, também, a tragédia udenista, que não apenas assistiria à volta triunfante de Vargas, mas passaria o resto do período amargando seu lugar na oposição.

Nem mesmo a morte de Getúlio, em agosto de 1954, ou a vitória de Jânio Quadros, nas eleições de 1960, favoreceriam o acesso da legenda ao almejado espaço no poder. No primeiro caso, a UDN sequer faria o sucessor, além de sofrer a diminuição de suas forças, em contraposição ao fortalecimento da aliança PSD-PTB. No segundo, embora formalmente compusesse a base governista, a sigla conviveria com o desleixo do presidente, que se colocara acima da estrutura partidária e pouco se esforçava por manter o apoio dos udenistas (BENEVIDES, 1981a; SKDIMORE, 1975). Para frustração do maior partido da oposição, restava-lhe, como tal, ceder aos assédios do governo, única alternativa para dele participar.

\footnotetext{
5 Esta é a leitura de Benevides (1891a). Skdimore (1975, 91-92), no entanto, discorda sobre este ponto, sugerindo que os esforços de alguns líderes udenistas não foram capazes de conter a postura oposicionista da bancada ao governo Dutra, que só teria contado com a colaboração do partido em seu primeiro ano de mandato, antes da outorga da Carta de 1946.

${ }^{6}$ A autora sugere que a escolha de um nome consensual tenha sido mesmo sabotada pelo PSD tão logo a legenda percebeu que "no contexto daquela nova ordem social, um pacto exclusivamente conservador representaria um suicídio político". A partir de então, a cúpula pessedista teria começado a estudar as bases para uma aliança eleitoral e parlamentar com o PTB (BENEVIDES, 1981a, p. 220).
} 
Em que pesem exclusivamente as questões doutrinárias, a literatura sugere que um alinhamento do gênero não se revelaria custoso para a maior parte dos udenistas em virtude da clara identificação ideológica existente entre eles e os pessedistas. A origem comum dos partidos (de penetração nas zonas rurais, agrícolas e menos desenvolvidas) aproximaria as relações políticas características dos quadros do PSD e da UDN, que repousavam sobre laços tradicionais e conservadores (BENEVIDES, 1979, p. 133) ${ }^{7}$.

Normalizando composições ad hoc no pré-64, este tipo de conciliação respaldaria, porém, uma série de avaliações negativas sobre o quadro partidário da época, como sinônimo da fragilidade das legendas, consideradas organizações débeis e fisiologistas. Foi justamente tal consideração que motivou, inclusive, Sérgio Abranches (1988) a cunhar o termo “presidencialismo de coalizão", expressão inspirada na conhecida prática de formação de alianças pós-eleitorais pelo chefe do Executivo no intuito de ampliar o apoio legislativo ao seu programa de governo em troca de participação efetiva no mesmo aos partidos então aliciados, típica dos regimes parlamentaristas, embora vigente no Brasil presidencialista do pré-64. O autor temia os resultados provenientes da repetição de uma estratégia política associada, a seu ver, ao enfraquecimento da capacidade decisória, sob o novo regime inaugurado pela Carta de 1988. Sua condenação da organização do Executivo em amplas coalizões devido às demais escolhas institucionais adotadas pelos constituintes - a saber: o presidencialismo e a representação proporcional (RP) de lista aberta - fundava-se na suposta tendência à instabilidade de governo.

Nada positivo, portanto, é o balanço formulado pela literatura que se dedicou ao exame da organização dos quadros partidários e do próprio sistema político de 46-64 até

\footnotetext{
${ }^{7}$ Eis a razão para a aliança PSD-UDN não se revelar interessante do ponto de vista eleitoral: os partidos não se unem "basicamente porque disputam a mesma área". Isto não impediria, todavia, que se compusessem no Congresso para levar a cabo uma "vigilância conservadora" em face ao Executivo (BENEVIDES, 1979, cap. III), estendida "contra tudo o que pudesse ser interpretado como 'subversão', ou como ameaça aos interesses dos proprietários de terras ou 'proletarização' das classes médias” (BENEVIDES, 1981, p. 278-79) - uma bandeira nomeadamente udenista, sob a qual se apoiaria a ala mais radical do partido para justificar a contínua não-adesão ao governo.
} 
meados da década de 1980. Investigações de cunho predominantemente sociológico, os trabalhos atrelavam à precária institucionalização das legendas na democracia populista o comprometimento da governabilidade no período, em face da incongruência ideológica e do fisiologismo a coordenar a conduta daquelas siglas.

Ganhando força nos anos 2000, estudos da mesma experiência democrática a partir das regras internas que norteiam o processo decisório amargariam avaliação similar. Os resultados substantivos alcançados em plenário atestariam a prevalência de coalizões de ocasião, formadas segundo os interesses imediatos dos parlamentares assediados pelo governo.

\subsection{Predomínio de coalizões ad hoc}

Análises sobre a influência das regras que formalizam o processo decisório na República de 1946 frente aos saldos políticos obtidos se tornaram mais comuns após o impacto dos achados da abordagem neoinstitucionalista para a democracia atual, que desmantelou as previsões negativas da literatura delineadas nos anos imediatamente subseqüentes à redemocratização do país ${ }^{8}$. Até então, existiam poucos estudos, destacadamente exploratórios, enfocando os resultados substantivos administrados na democracia populista a partir da pesquisa acurada do processo decisório, molde a regular as relações entre governo e Congresso.

Um dos primeiros esforços nesse sentido data de 1977, quando Maria Izabel Carvalho Valladão finaliza sua dissertação de mestrado, intitulada A Colaboração do Legislativo para o

\footnotetext{
${ }^{8}$ A referência aludida aqui se dirige às evidências reunidas nos trabalhos de Figueiredo e Limongi (1995, 1999, 2000, 20002), responsáveis por despertar os analistas para a não consumação dos prognósticos desanimadores aventados pela geração de estudos antecessora, que se fundamentavam na crítica à combinação entre presidencialismo, federalismo e sistema proporcional de lista aberta, ratificada na Constituinte de 1988, para alegar a nossa natural inclinação à ingovernabilidade, realidade a ser atingida em questão de tempo (LIMA JUNIOR, 1983; LAMOUNIER, 1994; SARTORI, 1983). Os termos desse novo debate é retomado logo adiante.
} 
Desempenho do Executivo durante o Governo JK. Homônimo, o esforço da autora perpassa a apreciação das votações nominais ocorridas ao longo da administração Kubitschek, distinguindo as questões que se mostraram objeto de acordo entre os quatro maiores partidos do período - quais sejam, PSD, UDN, PTB e PSP - daquelas onde o conflito entre as referidas siglas foi inevitável. Sua constatação foi pela preponderância de um padrão de colaboração entre oposição e situação, pois os udenistas, formalmente alheios à coalizão governista, estiveram com mais frequiência alinhados aos interesses da base de sustentação do mandato de Juscelino (PSD-PTB) do que em dissenso com a mesma. Na visão da autora, “o processo deliberativo consensual prevalecente entre as bancadas [teria sido] acompanhado pelo predomínio de entendimentos entre as facções políticas intrapartidárias" (CARVALHO, 1977, p. 57, grifo meu).

Confirmavam-se, assim, as conjecturas da leitura convencional, que destacava a elevada recorrência das composições ad hoc no pré-64. Indícios no mesmo sentido seriam levantados por Wanderley Guilherme dos Santos (1986) ao examinar, em profundidade, 18 deliberações nominais ocorridas no governo Goulart sobre as matérias que julgava mais importantes naquela conjuntura, bastante crítica. Visando compreender o comportamento legislativo entre 1959 e 1966, o autor constataria as mudanças do comportamento partidário em função do núcleo das questões votadas, o que incidiria sobre as coalizões parlamentares, variando sua composição.

Entretanto, o debate ganho novo fôlego em 1998, quando Figueiredo e Limongi revisitam a democracia populista à luz de seus próprios achados para o pós-88. Comparando o papel da Câmara dos Deputados, a produção legislativa e o apoio partidário à presidência em ambas as experiências democráticas, os autores alertam que, pela leitura dos índices de semelhança e de Rice, o partido não parecia ser um bom preditor do voto do parlamentar no pré-64, diferentemente do que ocorre no período atual. A despeito da consistência ideológica 
da conduta do plenário no pós-88, quando coalizões são formadas por legendas adjacentes que tendem a manter constante sua posição, Figueiredo e Limongi entenderam que, durante a República de 46, a norma parece ter sido o recurso a conformações mais maleáveis, concebidas especialmente para o momento, em virtude de interesses de ocasião ${ }^{9}$.

Mesmo supondo que a disciplina mais baixa verificada na República de 1946 se comparada à taxa encontrada no pós-88 decorra da maior heterogeneidade das matérias sendo votadas, inclusive em função da maior abertura do Congresso à apreciação de políticas paroquialistas ou $\operatorname{localistas}^{10}$, os autores creditam a atual capacidade governativa do presidencialismo brasileiro à ampliação dos poderes legislativos do presidente - iniciada no interregno militar -, e à centralização decisória na Câmara em torno da Mesa Diretora e do Colégio de Líderes - institucionalizado pelo Regimento Interno da Casa de 1989. Isto porque as referidas inovações, para além de induzir a disciplina das bancadas, teriam viabilizado a formação de coalizões governamentais estáveis, mesmo em um regime presidencialista e multipartidário - diferentemente do observado no pré-64, quando tais fórmulas não existiam (FIGUEIREDO, LIMONGI, 1998, 1999, 2000, 2002).

Novas especulações nesta perspectiva se sucederiam. Permanece o desafio de se explicar como o chefe do Executivo administrava as dificuldades em reunir apoio efetivo, assumindo-se por incerta a participação das agremiações políticas no Congresso dado o histórico clientelista que abatia todo o quadro partidário da primeira experiência democrática. A grande oscilação na própria base formal de apoio ao presidente motivava o reexame do período, já que muitas seriam as recomposições acordadas entre as siglas.

\footnotetext{
${ }^{9}$ Segundo Limongi \& Figueiredo, o plenário do período anterior parece menos polarizado do que o do período atual. "A maioria do PSD tendeu a dominar o plenário e o fez fazendo alianças circunstanciais à direita e à esquerda. No governo Dutra e no governo Café Filho, o partido tendeu mais à direita. No restante do período, tendeu mais à esquerda, juntando-se, em geral, ao PTB e, também, ao PSP" (LIMONGI, FIGUEIREDO, 1998, p. 18).

10 Também conhecidas por pork barrel, tratam-se de medidas distributivistas propostas por parlamentares engajados em dirigir recursos públicos para seus respectivos redutos eleitorais. Para mais, vide Mayhew (1974).
} 
De fato, firmaram-se nada menos do que 19 coalizões de governo entre 1946-1964 (excluindo-se a curta interinidade de Mazzili em setembro de 1961), com duração média de 13 meses, conforme aponta o Anexo $\mathrm{A}^{11}$. Contudo, a autora ressalta que mais de um terço das mudanças (para ser exata, 37\%), devem-se ao calendário eleitoral regular, não sendo resultado, portanto, de conflitos no interior da coalizão (FIGUEIREDO, 2008, p. 195).

Todavia, não faltariam motivos para possíveis indisposições entre os integrantes da base governista, sobretudo quando se considera que a UDN esteve na retaguarda do PTB em número de pastas ministeriais apenas durante os governos JK e João Goulart, conservando mais recursos de poder, enquanto se fazia "oposição", em comparação aos trabalhistas, quase sempre "situação" (SANTOS, 2003, cap. X).

Tal arranjo de forças amplia a suspeita em torno da possibilidade de negociação da contribuição de setores udenistas na passagem da agenda presidencial, uma vez considerada a probabilidade da aliança PSD-PTB não se mostrar suficiente para a aprovação dessas políticas, como Santos (2003) adverte ter ocorrido ao longo de todo o período - à exceção da administração Goulart, a única que poderia ter contado integralmente com uma coalizão formada apenas por pessedistas e trabalhistas para construir um governo estável (Ibid, p. 275).

Outros estudos compartilhariam tese semelhante, pela qual os assédios do governo à oposição, barganhando colaboração durante as votações de matérias do interesse do Executivo em apreciação no plenário da Câmara dos Deputados, se fariam cruciais para se afiançar a governabilidade, com freqüência, abalada (AMORIM NETO, SANTOS, 2001; SANTOS, 2002).

Em pesquisa semelhante à de Figueiredo e Limongi, Fabiano Santos (2002) também confronta as constituições brasileiras de 46 e 88, observa o apoio do líder da maioria e a coesão dos partidos nos projetos do Executivo votados na Câmara dos Deputados através do

\footnotetext{
${ }^{11}$ Vide p. 133.
} 
cálculo do índice de Rice, aplicado a um conjunto previamente selecionado de votações. No caso da primeira experiência democrática, consideram-se as relativas a matérias desenvolvimentistas apreciadas nos governos Getúlio Vargas e Juscelino Kubtischek e, para o momento atual, àquelas deliberações sobre emendas à Constituição de 1988 que tiveram lugar durante o primeiro mandato de Fernando Henrique Cardoso. $\mathrm{O}$ autor concorda sob a necessidade dos presidentes populistas precisarem firmar alianças pós-eleitorais como alternativas para expandir a maioria e diminuir a imprevisibilidade dos resultados obtidos em plenário. Todavia, seu julgamento é muito mais categórico no que tange à discussão da manutenção dos padrões políticos tradicionais.

A seu ver, há indícios de que o presidente precisava negociar individualmente com membros da oposição para obter apoio parlamentar excedente, "como um seguro contra o espectro de um comportamento indisciplinado de sua base formal", constituindo coalizões ad hoc mediante a distribuição marginal de patronagem, quando se tratava de aprovar policy relevante (SANTOS, F., 2002, p. 246-247). Daí o padrão de coalizão em torno da agenda presidencial se revelar significativamente diverso nos dois períodos.

No pré-64, partidos divididos, coalizões amplas envolvendo parcelas relevantes de partidos oposicionistas caracterizariam o que o autor chamou de modelo brasileiro de sistema presidencialista faccional. A transição para um sistema de coalizão racionalizado, verificado no período recente, seria acompanhada pelo advento de um padrão consistente de governo versus oposição, com razoável disciplina entre os diversos parceiros do governo e alta disciplina por parte da oposição (SANTOS, F., 2002, 2003).

A ampliação da capacidade do presidente intervir no processo legislativo, produto direto da transferência de poderes decisórios ao Executivo, iniciada no país com o golpe de 1964 e posteriormente ratificada pela Constituição de 1988, teria criado um forte estímulo para a organização dos deputados federais em partidos parlamentares. Isto, por sua vez, 
aumentara a disciplina e a previsibilidade dos legisladores em plenário na contramão do que normalmente se observava na experiência democrática pregressa, quando a patronagem constituía a estratégia mais relevante na busca de apoio pela aprovação do programa presidencial na Câmara (SANTOS, F., 2002, 2003).

Fato é que a tentativa mais elaborada de se testar a patronagem como variável dependente da disciplina partidária na democracia de 1946 foi realizada por Amorim Neto e Santos (2001). Intrigados com a notável variação nas taxas de apoio ao governo apresentadas pelas legendas do período ao longo do tempo e com a concentração das taxas mais altas de disciplina nos maiores partidos, os autores pressupunham viável a hipótese de que a taxa de apoio ao governo no período poderia decorrer, sobretudo, das estratégias dos presidentes para a formação de coalizões parlamentares por meio da distribuição aos partidos de recursos de patronagem - o que denominaram conexão presidencial.

Parte desta suposição reside na interpretação dos autores tecem de Riker (1962). Como explicam,

Suponhamos um regime presidencialista em que o Poder Legislativo é fragmentado e os partidos são pouco disciplinados. Quais os efeitos desses fatores para a articulação de coalizões parlamentares? Há duas conseqüências correlacionadas: (a) a fraca disciplina leva ao que Riker (1962,77-101) denomina de efeito-informação, que ocorre toda vez que os políticos que estão montando uma coalizão não dispõem de informações completas sobre a força relativa dos parceiros, desconhecem seu grau de lealdade e não têm informações perfeitas sobre os passos anteriormente dados pelos parceiros na coalizão; (b) em conseqüência do efeito-informação, o somatório da força parlamentar dos partidos que formalmente pertencem à coalizão governista é um número que não corresponde às posições políticas desses partidos no Congresso (AMORIM NETO, SANTOS, 2001, p. 295, grifo dos autores) 
Na prática, isto significaria que a disciplina partidária seria tão menor quanto maior se mostrasse o efeito-informação, e quanto maior ele fosse, mais fortes seriam os incentivos para formar coalizões sobredimensionadas a fim de diminuí-lo. Numa Câmara Baixa fragmentada como a brasileira, isso se refletiria em tendência a "altas taxas de deserção e freqüente recomposição de coalizões", já que "mais espaço [existiria] para a manipulação da agenda política e para a adoção de comportamentos estratégicos por parte da liderança do partido e dos seus demais integrantes". Conseqüentemente, "as coalizões [teriam] de ser formadas caso a caso, conforme a questão em jogo, e para cada uma [haveria] uma composição diferente de parceiros" (AMORIM NETO, SANTOS, 2001, p. 295).

Daí os autores conjecturarem que todos os presidentes - os atores mais interessados em garantir estabilidade ao longo da legislatura - tentaram criar uma "facção governista" dentro das principais legendas da época, utilizando a patronagem como moeda de troca, uma vez que esta opção se fazia extremamente atraente aos parlamentares, verdadeiros lobistas a disputar os recursos, concentrados nas mãos do Executivo, para atender às demandas regionais por eles representadas.

Utilizando como proxy um indicador de verbas orçamentárias alocadas aos partidos pelos presidentes, Amorim Neto e Fabiano Santos concluíram que "a variação das taxas de disciplina ao longo do tempo devia-se ao decurso do mandato presidencial". Sem o imperativo da reeleição, “a capacidade dos presidentes para manter a lealdade das facções governistas diminuía à medida que seu mandato se esgotava”. Disso decorreria a redução das taxas de disciplina partidária, em virtude da diminuição das facções que lhe davam apoio (Ibid., p. 301).

Os autores ainda encontram taxas mais altas de disciplina nos partidos grandes, justificando o achado em termos da própria magnitude das legendas, que as tornava as de maior relevo, para onde "fluía o grosso dos limitados recursos de patronagem disponíveis para 
os presidentes" (AMORIM NETO, SANTOS, 2001, p. 302). Pelo mesmo motivo, inclusive, as maiores siglas encerrariam facções governistas maiores em comparação aos partidos pequenos.

Muito embora admitam ser exatamente por intermédio das facções e lideranças clientelistas que os presidentes brasileiros encontravam maior facilidade para negociar quando precisavam de apoio político, Amorim Neto e Santos não se interessaram por levar a cabo um estudo mais aprofundado, na tentativa de rastrear os parlamentares que fizeram parte dessa dinâmica pró-governo. Mesmo citando algumas obras sobre os principais partidos da época, duas das quais nomeiam os principais representantes de cada facção abrigada no interior de uma mesma agremiação, os autores não vislumbraram uma pesquisa qualitativa desses grupos.

Resta inexplorada, portanto, a incômoda dúvida sobre a concreta relevância do faccionalismo enquanto variável explicativa do comportamento legislativo na democracia de 46. Esclarecê-la exige, porém, enveredar por uma discussão prévia, fundamentalmente téorica, sobre a noção de facções políticas, que é oferecida a seguir.

\subsection{Facções partidárias: opções de barganha}

A debilidade de pesquisas relativas ao faccionalismo não constitui exclusividade brasileira. Em artigo onde se propõe a repensar o tema, Boucek (2009) enfatiza a limitação da academia nesta linha de estudo. As raras análises existentes tenderiam, segundo o autor, a oscilar entre investigações demasiado quantitativas até abordagens puramente intuitivas, quase inexistindo exames comparativos. Além disso, os estudos não se revelariam capazes de "capture group dynamics and explain the process of change", sobretudo porque se limitariam a elaborar tipologias "based on subparty group categories with different features", oferecendo 
uma visão estática do facciosismo e, por extensão, respostas pouco convincentes às questõeschave de pesquisa, como o motivo de "some political parties contain factions while others do no" (BOUCEK, 2009, p. 2).

Muito provavelmente, a inexistência de uma agenda de pesquisa consolidada sobre o fenômeno decorreria da própria conotação negativa que o termo "facção" assumiu desde sua origem (BOUCEK, 2009), sendo por muito tempo empregado como sinônimo de "um grupo político empenhado em um facere perturbador e danoso", ao passo que a idéia de "partido", transmitindo a idéia de parte, encerrava um tom mais neutro, já que "a parte não é, em si, uma palavra depreciativa" (SARTORI, 1983, p. 24, grifo do autor).

Contudo, se abstraímos o caráter valorativo normalmente imputado às facções, definindo-as simplesmente como "organizational units of political competition", como sugerem Belloni e Beller (1978, p. 447), o exame da experiência brasileira se revela ainda mais tentador, sobretudo pela ampla cobertura dos episódios que teriam despertado a emergência de dissidências intrapartidárias à concorrência, tão noticiados pelas fontes bibliográficas. Se a praxe realmente era assediar a oposição visando reunir maiorias para atender a interesses de ocasião, essa dinâmica deve ser apreendida pela análise do facciosismo, dado que o aspecto mais significativo da política de facção é a dinâmica (BELLONI, BELLER, 1978).

Todavia, endossar a tese das coalizões ad hoc como norma na democracia populista perpassa por comprovar dois fatos. Primeiro, que a base de apoio ao governo não era capaz de dar suporte à passagem da agenda do Executivo nas deliberações em plenário, ou mesmo não creditava ao presidente a segurança necessária para evitar o cortejo deste perante a oposição. Segundo, é preciso constatar a existência de grupos que cederiam aos assédios do governo e com ele se comporiam justamente para assegurar o alcance de objetivos específicos, estabelecidos em função da própria conjuntura política. Neste caso, a propalada hipótese da 
predominância do facciosismo no período encontraria terreno, "considering factions as intraparty groups that act collectively in order to achieve common goals"12, se verificada a não adesão de determinadas dissidências no interior das legendas da coalizão governista ao programa situacionista e, na contramão, a colaboração de determinadas cisões, na oposição, ao plano de trabalho presidencial com alguma sazonalidade. A questão temporal, assim, seria a proxy da unidade destes estratégicos focos de administração da governabilidade.

No que diz respeito à primeira premissa, sobre a insegurança do governo perante a contribuição da sua própria base para com a sua estimada agenda de trabalho, é bem verdade que a coesão partidária daquela época era menor em relação à experiência democrática atual. Basta observarmos as taxas médias do índice de Rice - amplamente utilizado na medição dessa categoria - para as coalizões que encerraram o maior número de votações nominais na República de 1946 - todos abaixo de 80,0 (tabela 1.1$)^{13}$.

Tomando por referência apenas i) as votações válidas nas quais ao menos $10 \%$ dos deputados votaram contra o resultado final, ii) os partidos responsáveis por, no mínimo, 10 votos válidos em cada deliberação e iii) as coalizões com maior número de decisões a ultrapassar o quorum legal, o cenário encontrado para a democracia populista não se revela o melhor dos mundos ${ }^{14}$. A faixa média das legendas em Vargas e JK, da ordem de $60 \%$,

\footnotetext{
${ }^{12}$ Esta é a definição adotada por Verge e Gomez $(2011$, p. 3) e constitui uma síntese das interpretações disponíveis em outras fontes, como os próprios autores assumem - tratam-se das visões de Belloni e Beller, (1978, p.447), Boucek (2009, p. 14) e Zariski (1960, p. 33) sobre o faccionalismo.

${ }^{13} \mathrm{O}$ índice de Rice é obtido através do resultado, em módulo, da subtração da porcentagem de votos contrários encerrados por uma legenda $\mathrm{X}$ a partir da porcentagem de votos favoráveis registrados pela mesma sigla numa dada votação nominal Y. Ou seja, $R y, x=\mid \%$ de votos sim - \% de votos não|. Sem levar em consideração, portanto, os casos de abstenção declarada, as ausências e a obstrução parlamentar, abrangendo apenas os deputados que votaram pela aprovação ou rejeição da matéria em deliberação, os escores calculados invariavelmente somam 1 (um). Disso se depreende que, na prática, um partido só atingirá um escore de 100\% no índice de Rice caso todos os seus membros votem da mesma forma durante uma deliberação nominal. Por extensão, o indicador cairá para 0 (zero) se a agremiação rachar ao meio, isto é, quando o número de votos sim equivaler à soma dos votos não (Rice, 1925).

${ }^{14}$ Exatamente por se tratar de uma média, o índice de Rice exige certo cuidado. Do ponto de vista estatístico, faz-se mister se estabelecer um ponto de corte sobre um mínimo de votos necessários ao seu cálculo, uma vez que "pequenos e micros partidos têm, necessariamente, seus índices inflados para cima" (FIGUEIREDO, LIMONGI, 1998, p. 15). Já do ponto de vista conceitual, é insensato construir escores para votações nominais visivelmente consensuais e, como tais, insignificantes em termos de conflito partidário.
} 
estavam longe de refletir uma conjuntura de destacada confiabilidade em termos de disciplina partidária. O pequeno incremento dos escores em decisões sobre matérias iniciadas pelo Executivo ainda não assegurava uma situação totalmente confortável para o governo, a ver pelas taxas baixas amargadas no interior da própria coalizão:

Tabela 1.1 - Índice de Rice médio, segundo a origem da matéria em votação*

\begin{tabular}{|c|c|c|c|c|c|}
\hline \multirow{3}{*}{ Coalizão } & \multirow{3}{*}{ Partidos } & \multicolumn{4}{|c|}{ Origem } \\
\hline & & \multicolumn{2}{|c|}{ Executivo } & \multicolumn{2}{|c|}{ Legislativo } \\
\hline & & $\mathbf{N}$ & Rice médio & $\mathbf{N}$ & Rice médio \\
\hline \multirow{6}{*}{ Vargas I } & PSD & 29 & 59,5 & 52 & 51,5 \\
\hline & PSP & 27 & 73,7 & 50 & 55,6 \\
\hline & PTB & 29 & 65,3 & 52 & 54,7 \\
\hline & UDN & 29 & 57,8 & 52 & 44,1 \\
\hline & Plenário** & - & 33,7 & - & 32,7 \\
\hline & Coalizão*** & - & 60,3 & - & 43,8 \\
\hline \multirow{6}{*}{ Vargas II } & PSD & 25 & 53,9 & 77 & 54,6 \\
\hline & PSP & 19 & 57,5 & 66 & 48,2 \\
\hline & PTB & 25 & 41,7 & 77 & 45,1 \\
\hline & UDN & 25 & 37,3 & 77 & 49,3 \\
\hline & \begin{tabular}{|l|} 
Plenário \\
\end{tabular} & - & 38,4 & - & 36,8 \\
\hline & Coalizão & - & 45,9 & - & 45,8 \\
\hline \multirow{6}{*}{ JK I } & PSD & 61 & 60,2 & 109 & 59,6 \\
\hline & PSP & 60 & 58,1 & 109 & 52,9 \\
\hline & PTB & 61 & 52,7 & 109 & 56,0 \\
\hline & UDN & 61 & 64,1 & 109 & 56,7 \\
\hline & \begin{tabular}{|l|} 
Plenário \\
\end{tabular} & - & 31,6 & - & 33,3 \\
\hline & Coalizão & - & 47,0 & - & 48,1 \\
\hline \multirow{6}{*}{ JK II } & PSD & 12 & 71,6 & 30 & 59,6 \\
\hline & PSP & 12 & 61,4 & 30 & 59,7 \\
\hline & РТВ & 12 & 61,5 & 30 & 57,9 \\
\hline & UDN & 12 & 65,4 & 30 & 48,8 \\
\hline & Plenário & - & 37,7 & - & 34,3 \\
\hline & Coalizão & - & 57,4 & - & 51,8 \\
\hline
\end{tabular}

*Considera apenas os escores de legendas que somaram, no mínimo, 10 votos por deliberação. **Agrupa todos os votos sim e não manifestos em cada votação. ***Trata os partidos que compõem a coalizão como um partido único.

Fonte: Banco de Dados Legis lativos, Cebrap.

Também é preciso definir o número de deliberações necessárias para se tornar um recorte do universo digno de análise individualizada. Afinal, poucas observações podem deturpar a interpretação dos saldos políticos substantivos resultantes da distribuição das preferências dos legisladores, comprometendo quaisquer inferências posteriores. 
Como vimos, a literatura partilha desse diagnóstico, seja pelo exame dos dados da dinâmica legislativa no pré-64 (FIGUEIREDO, LIMONGI, 1998; SANTOS, F., 1997, 2003; SANTOS, 2003), seja por crônicas conjunturais, de cunho marcadamente sociológico, enfáticas nas dificuldades do Executivo consolidar compromissos duráveis no Congresso Nacional (BENEVIDES, 1981a, 1981b; D’ARAÚJO, 1992; SKDIMORE, 1975). No entanto, este segundo grupo vai além, sem economias ao conjecturar a vigência da segunda condição a satisfazer o enquadramento da República de 46 aos ditames do facciosismo - isto é, a observância de cisões ideológicas no seio dos grandes partidos da época capazes de serem mobilizadas tão logo se fizessem imprescindíveis conformações ad hoc. A despeito de inexistir empenho na checagem efetiva da ocorrência, da eficiência e da composição das tão apregoadas dissidências partidárias potencialmente assediadas pelo governo para reunir maiorias legislativas no pré-64, há uma diversidade de alusões textuais às razões que fomentariam a emergência de tais facções, não raro seguidas de uma lista com os supostos nomes dos "rebeldes".

Com efeito, os dois trabalhos mais apurados sobre os dois principais partidos da época - isto é, a União Democrática Nacional (UDN) e o Partido Social Democrático (PSD) relatam inúmeros casos de desacordo intrapartidário, contextualizando o conflito e enumerando muitos dos atores então envolvidos. Tomados em conjunto, inclusive, as narrativas autorizam supor que o imperativo da liberação das bancadas em matérias polêmicas associado às querelas em torno de alianças eleitorais, estimuladas que eram por desentendimentos em torno do lançamento de candidaturas e coligações, e aos conflitos sobre a melhor estratégia parlamentar, normalmente catalisados por cálculos regionais destoantes, faziam da nossa primeira experiência democrática o cenário, por excelência, do facciosismo.

A considerável autonomia de que gozavam os filiados de ambas as siglas no processo de votação, liberdade esta totalmente condizente com a própria diversidade ideológica dos 
grupos de parlamentares que se reuniam sob tais legendas, pode ser lida como o estímulo inicial para um comportamento parlamentar, no mínimo, independente - e que daria margem para o presidente barganhar votos na oposição. Isso porque, da mesma forma que um comportamento indisciplinado era facultado à base governista, a oposição também não era forçada a seguir a preferência de seus líderes partidários, o que talvez fosse mesmo inalcançável.

Em sua narrativa sobre o "udenismo", Benevides (1981a, p. 172) realça a impossibilidade da bancada do principal partido de oposição chegar a um consenso, uma vez que I) o conflito entre as bancadas federais e a Comissão Executiva do Diretório Nacional, era a regra e II) as divergências entre os udenistas se revelavam significativas, tanto por motivos regionais como de grupos políticos - os legalistas e os golpistas, os bacharéis e os realistas, os nacionalistas e os 'entreguistas', a 'Banda de Música' e a 'Bossa Nova'. Diante disso, soaria bastante coerente a opção da legenda que, em matéria de votação [...] nunca propunha questão fechada (Idem).

Afinal, atitudes coerentes com os apaixonados discursos registrados nos Anais da Câmara dos Deputados e declarações veiculadas na imprensa da época inviabilizariam, em tese, a mesma escolha de voto realizada por nomes como Adaucto Lúcio Cardoso, Afonso Arinos, Aliomar Baleeiro, Bilac Pinto e Jose Bonifácio - expoentes do grupo que ficou conhecido como Banda de Música, devido ao barulho que faziam no plenário com sua oratória inflamada e, muitas vezes violenta, aparteando ou discursando diariamente contra o governo - e a preferência de João Cleófas, Virgílio Távora, Leandro Maciel e Antônio Carlos Magalhães - principais representantes dos Chapas-Brancas, uma ala udenista formada por parlamentares, sobretudo do Nordeste, sensíveis às possibilidades de aproximação com o governo (Ibid, p. 84-85). 
Aliás, o regionalismo se revelava um multiplicador de interesses, correntes e linhas de ação no interior do partido. Segundo a autora, havia "uma total autonomia dos diretórios regionais para fazer coalizões, selecionar candidatos, angariar e utilizar recursos financeiros, organizar e desenvolver campanhas eleitorais e outras" liberdades não regradas pelo Diretório Nacional (Ibid. 167). Deste modo, para além dos grupos políticos acomodados dentro da legenda, que chegaram a divergir radicalmente quanto às políticas da sigla e também em termos de "estilo", seria ainda possível reconhecer as várias UDNs estaduais num pacto nacional - o que Benevides atribui à "problemática do poder local” (BENEVIDES, 1981a, p. 224).

Admitindo o caráter multifacetado da UDN, cujas divisões internas mostravam-se patentes tanto na tribuna quanto na "dinâmica do plenário" (Ibid., p. 164), a autora por vezes procura rebater a postura negativista dos teóricos sobre 46-64, que facilmente tendiam a enquadrar a sigla como um movimento ou facção. Lembrando ao leitor que seu trabalho não se propõe "uma rígida preocupação conceitual e muito menos uma acareação impiedosa da realidade udenista com as virtudes de um 'autêntico' partido", Benevides (Ibid., p. 155) defende que, apesar da agremiação ter surgido como um movimento agregador das mais variadas tendências políticas e raízes históricas, a instituição se organizava como uma legenda, e não apenas como uma facção em luta pelo poder (Ibid., p. 156).

Embora aparentemente menos irreconciliáveis, as cisões internas também teriam motivado o PSD a liberar freqüentemente seus quadros em deliberações sobre matérias consideradas controvertidas pelos seus membros. Investigando o perfil dos pessedistas e a postura da bancada federal que teria, a seu ver, afiançado a estabilidade política da primeira experiência democrática, Hippólito (1985, p. 43) afirma que “o partido jamais fechou questão sobre matérias de natureza ideológica. Nesse caso, era livre o exercício do voto pelos 
parlamentares" $"$. Segundo a autora, a democracia interna só deixava de existir quando frações intrapartidárias, de cunho mais ideológico, começavam a disputar o poder dentro do partido. Aí sim "o comando nacional cerrava fileiras contra a dissidência, até conseguir destruí-la" (HIPPÓLITO, 1985, p. 43).

De fato, seria precipitado equiparar a autonomia das seções estaduais do partido ante o Diretório Nacional à experimentada pelas repartições subnacionais da UDN. Embora a estrutura federativa pessedista viabilizasse uma razoável liberdade às divisões regionais, a legenda restringia o comando nacional àqueles que tinham poder no seu estado, que tenderam a usar sua influência e poder de veto para frear tentativas de modernização da liderança, impedindo a renovação das elites partidárias (HIPPÓLITO, 1985, p. 121-27).

Tratavam-se das raposas, como ficaram conhecidos os pessedistas tradicionais, contrários as idéias trazidas pelos reformistas - também chamados de Ala Moça, grupo renovador, estreitamente vinculado à candidatura e ao governo de Juscelino e disposto a revitalizar os métodos do PSD, adaptando-o às novas solicitações colocadas em debate já durante a campanha Kubitschek. Para Hippólito, reside na Ala Moça e em seu conflito com a oligarquia pessedista, inclusive, a origem da fragmentação interna do PSD enquanto partido situado no centro do sistema partidário e, exatamente por isso, fiador da estabilidade política do regime 46-64 (Ibid., p. 141).

Nem mesmo na hipótese de um cenário mais coeso, onde raposas e reformistas não se digladiariam por maior influência na linha de ação do partido, porém, a situação majoritária da legenda, que contabilizou a maior bancada ao longo de toda a República de 1946, constituiria condição suficiente para ser capaz de governar sozinha, como Hippólito reitera em várias passagens. $\mathrm{Na}$ inexistência de regulação regimental obrigando a presença de todos os

\footnotetext{
15 Oliveira (1973) já destacara esse ponto, enfatizando o considerável grau de independência gozado pelos pessedistas durante as votações em função da flexibilidade da liderança do partido, que não reclamava obediência constante.
} 
parlamentares no momento da votação e do estatuto da fidelidade partidária a forçar cada filiado a emitir um voto coerente com a indicação da sigla, sob risco de perda de mandato, tornava-se impossível à liderança pessedista garantir a presença de todos os seus no momento das deliberações, tampouco assegurar que todos os votos dados em nome da sigla seguiriam a sua orientação (Ibid., p.63-64).

Realmente, Wanderley Guilherme dos Santos (2003) demonstrou que nem mesmo a reunião do maior partido da época aos trabalhistas, firmando a coalizão de forças formal mais freqüente do período, seria capaz de amparar os governos do pré-64, à exceção de Goulart, o único que poderia ter contado apenas com o apoio da aliança PSD-PTB. Em todos os demais, seria necessário contar com o apoio de outras siglas, uma vez que tal plataforma não se revelaria suficiente para a aprovação de políticas.

Ao que tudo indica, a contribuição decisiva residiria no auxílio dos parlamentares udenistas, que superariam, inclusive, os trabalhistas em número de ministérios até mesmo durante o segundo governo $\operatorname{Vargas}^{16}$ - situação aparentemente inimaginável, tanto pelo fato do presidente em exercício ser o fundador do PTB quanto pela razão de ser da UDN residir no antigetulismo. Uma das alocações ministeriais em prol do principal partido de oposição, porém, não apenas justificaria a provável ajuda udenista dirigida ao Executivo, mas representaria os termos da instauração e agência das facções: a falta de consenso sobre a melhor estratégia parlamentar, variável em função das alianças eleitorais assumidas e dos interesses regionais em jogo.

Refiro-me à nomeação de João Cleófas (UDN/PE) para a pasta da Agricultura, em 1951. Segundo a literatura, ela não se resumia a mais uma manobra da conhecida "política de conciliação" aventada por Getúlio desde a posse. Expressava, antes, um débito do presidente com a seção pernambucana da UDN, liderada por Cleófas - candidato derrotado ao pleito

\footnotetext{
${ }^{16}$ Somente nas administrações de JK e Goulart a UDN comandaria menos pastas ministeriais que o PTB (cf. SANTOS, 2003, cap. X).
} 
estadual -, que apoiara a candidatura de Vargas quando o PSD regional, conduzido por Agamenon Magalhães, aderiu à campanha de Cristiano Machado ${ }^{17}$ (D’Araújo, 1992; Skidmore, 1975).

Desconfortável perante a aceitação do pernambucano ao cargo, o que teria iniciado uma polêmica quanto à participação da UDN na administração varguista, a direção nacional da legenda teria se empenhado em esclarecer que "isso não representava qualquer compromisso do partido com o Governo" (D’ARAÚJO, 1992, p. 119) ${ }^{18}$. Todavia, estaria posta a querela entre "as hostes udenistas mais arraigadas ([os]'autonomistas')" e a ala mais propensa a se render à sedução da proposta conciliatória - os "adesistas" (Idem). Enquanto lideranças do porte de Otávio Mangabeira defenderiam uma oposição sistemática a Getúlio, o "grupo sadio", do qual Afonso Arinos fazia parte, apreciaria as razões de uma aproximação à plataforma governista, desde que houvesse "sinceridade de propósitos" (Ibid., p. 122).

$\mathrm{Na}$ realidade, as várias descrições sobre os assédios de Vargas à UDN e as suas implicações rendem um painel de divisões intrapartidárias que potencialmente poderiam se refletir nas votações em plenário. Isso porque, segundo Skdimore (1975, p. 135), o presidente teria animado, durante os dois primeiros anos de governo, "um grupo de 'coordenadores' em suas abordagens destinadas a trazer a UDN para o governo".

Inexiste consenso sobre a eficácia dessa estratégia, até porque os udenistas parecem ter avaliado cuidadosamente as implicações de uma adesão formal em prol de Vargas para a imagem do partido ${ }^{19}$. Segundo D’Araújo (op. cit., p. 123), a questão central que se colocava

\footnotetext{
${ }^{17}$ Para Skdimore, inclusive, essa aliança se mostrara emblemática do caráter fisiologista das legendas da época, acentuado pelo regionalismo. Nas suas palavras, "Não se pode encontrar maior prova do caráter não-doutrinário dos partidos dos Estados economicamente atrasados!" (SKIDMORE, 1969, p. 106-107).

${ }^{18}$ Essa intransigência frente à não-adesão ao governo é que teria levado Vargas a abandonar seu plano inicial, de conceder até três ministérios para a UDN, embora nomes como Juraci Magalhães - então presidente da Companhia Vale do Rio Doce, que mais tarde assumiria a condução da Petrobrás - tenham se revelado mais acessíveis a uma possível política de conciliação (FONTES, CARNEIRO, 1966).

${ }^{19}$ Embora Skdimore (1975) considere totalmente falha às tentativas de aproximação empanadas pela situação, D’Araújo (1992) salienta que até 1953 "a UDN apresenta alguma disponibilidade para avaliar as propostas de composição ou de participação no Governo", "apesar de manter uma postura antigetulista" e "intransigente de não-colaboracionismo". Só mais tarde a sigla passaria "não apenas a se alhear das funções governamentais,
} 
para a UDN não era a mera participação no governo, mas o melhor modo de fazê-lo. Haveria adesão à administração varguista desde que fossem vislumbradas garantias de poder vir a se tornar governo ${ }^{20}$. Por ora, valeriam as diretrizes aprovadas na Convenção Nacional do partido, realizada em maio de 1953, que prescreviam aos udenistas: “1) 'oposição ao governo federal'; 2) 'não-participação no governo'; e 3) 'permanente colaboração sem prejuízo das liberdades de crítica, em todas as matérias legislativas do interesse público"” (D’ARAÚJO, 1992, p. 137, grifo meu).

Talvez se limite aos projetos de "interesse público" a possível contribuição dos udenistas na passagem da agenda presidencial - que, no caso, estaria além de preferências partidárias, secundárias em se tratando de políticas de tal teor -, mas há que se checar. O que é dado como certo - mas nem por isso deve ser deixado de ser colocado à prova - é o resultado negativo dos assédios varguistas em direção à UDN para a coesão interna do governo, com o levante da oposição de alguns líderes petebistas, “cuja insatisfação contra Vargas se fez óbvia em setembro de 1951, com a renúncia do único membro do PTB no Ministério - o Ministro do Trabalho, Dantas Coelho"21. As negociações com os udenistas ainda estimulariam "a zanga do PSD, que temia uma perda de prestígio caso a UDN ingressasse no governo".

É até mesmo possível que Getúlio tenha conseguido trazer para si o apoio de algumas cisões regionais da UDN, cujo cálculo político diferisse da orientação nacional. Há relatos de que seção mineira do partido, por exemplo, estaria disposta a cooperar com o presidente em deixando que o Governo resolva seus problemas sozinho, como ainda decide dificultar ao máximo e, se possível, obstruir as possibilidades do Governo" (D’ARAÚJO, 1992, p. 124-25).

${ }^{20}$ A oferta de cargos não seria decisiva para garantir o apoio incondicional da legenda. "Na perspectiva de Afonso Arinos e Odilon Braga, entre outros, a colaboração [seria] possível a partir de planos de governo, e não através de cargos ministeriais" (D’ARAÚJO, 1992, p. 122).

${ }^{21}$ Homem de confiança de Vargas, Dantas (PTB/DF) é apontado como um dos mediadores que sondavam as diversas correntes, a fim de trazer apoio extra para o governo. Fora ele, inclusive, que teria realizado o convite ministerial de Vargas a Cleófas. Nem por isto, porém, escaparia de desentendimentos com o presidente e o com próprio PTB. Substituído por Dinarte Dornelles na direção da legenda, ampliaria "a cisão do partido em fevereiro de 1952, quando [apoiou] uma convenção da União dos Ferroviários do Brasil, realizada no Rio de Janeiro, visando à criação da Frente Trabalhista Brasileira", que se pretendia um novo partido trabalhista (D’ARAÚJO, 1992, p. 121). 
troca de uma pasta ministerial e do apoio de Vargas a uma candidatura udenista para o governo estadual. Alberto Deodato (UDN/MG), o possível ministeriável, teria sido sondado por José Candido Ferraz (UDN/PI), responsável pelos contatos juntamente com Danton Coelho (PTB/DF) em fins de 1951 (D’ARAÚJO, 1992, p. 121-22).

D’Araújo (1992) conjectura que Vargas tenha ainda entregue a pasta da Viação e Obras Públicas para o udenista José Américo de Almeida, na reforma ministerial de 1953, almejando se aproveitar do conflito interno desencadeado no partido, que sabia contribuir para tornar mais manifesto diante da repercussão deste remanejamento, tentando assim extrair alguma colaboração (Ibid., p. 128-29).

O impacto do ex-ditador sob o novo regime, todavia, se faria valer antes mesmo da sua volta ao poder. A tentativa de se chegar a um consenso sobre um candidato de "união nacional", abandonada, levaria o PSD a lançar Cristiano Machado, como seu candidato oficial ao pleito das eleições de 1950. Contudo, apenas em Minas Gerais verificou-se um apoio capaz de oferecer a Vargas alguma ameaça real. Como informa Skdimore:

\footnotetext{
Nos outros Estados, 'entendimentos' com o PSD ou com facções dissidentes do partido, como no Rio Grande do Sul, asseguraram um apoio menos que entusiástico a Machado, senão o apoio tácito a Getúlio. Essa estratégia foi facilitada pelos contatos íntimos de Vargas com os ex-interventores que eram agora próceres do PSD. Ernani do Amaral Peixoto, concorrendo a governador do Estado do Rio de Janeiro, era um dos mais proeminentes. Era, também, genro de Getúlio. O apoio a Cristiano Machado, naquele Estado, foi mínimo (SKIDMORE, 1969, p. 105, grifo meu).
}

Contudo, os próprios resultados das urnas mineiras revelaram que vários dos líderes locais do PSD tinham estabelecido compromissos com Vargas. Até mesmo naquele estado, de forte coloração pessedista, Getúlio neutralizou a votação do oponente (Ibid, p. 109). Não parece infundada, assim, a afirmação de D’Araújo (1992, p. 23) relativa ao reflexo desta 
disputa eleitoral sob comportamento parlamentar da legenda, que teria optado pelo relaxamento da disciplina partidária, "liberando seus membros para que [tomassem] a posição que lhes [parecesse] mais adequada a seus interesses e compromissos", dada a patente desagregação do partido do governo frente à candidatura de Vargas.

Nem mesmo após a sua morte os cálculos políticos deixariam de considerar o impacto do getulismo. Os diretórios regionais de Pernambuco, Santa Catarina, Rio Grande do Sul e parte da bancada mineira teriam rompido com a cúpula pessedista em protesto à candidatura da chapa Juscelino Kubitschek-João Goulart para a campanha presidencial de 1955 sob o argumento de que tal composição se fazia "imprópria" em função da "instabilidade" causada pela morte de Vargas. Em abril do mesmo ano, os dissidentes então ofereceriam um candidato alternativo, Etelvino Lins (PSD/PE), que assumiria “a chefia da dissidência (liderada também por pessedistas notórios como Nereu Ramos, Peracchi Barcellos e Carlos Luz) e [contaria] ainda com apoio da ala da UDN contrária a candidatura de Juarez Távora” (BENEVIDES, 1979, p. 122).

Apesar de conseguir se firmar com o apoio dos demais diretórios, a candidatura JKGoulart estimularia o levante de cisões que, segundo Benevides, não se resolveriam inteiramente com a vitória de ambos: "crises na aliança e no interior de cada partido persistem durante todo o período" (Ibid, p. 123, grifo meu). A mais preocupante seria certa dissidência pessedista gaúcha, onde a legenda "se aproxima da UDN em estilo político, organização partidária e programática, afastando a liderança estadual da nacional do partido, principalmente quanto à questão de eventuais alianças com o PTB” (BENEVIDES, 1979, p. 121).

O debate sucessório para as eleições presidenciais de 1960 também é apontado como fonte de novas divisões. Lançado prematuramente, ele teria prolongado "as divergências na aliança e no interior de cada partido" (Ibid, p. 125, grifo meu). A legenda que teria maiores 
dificuldades em entrar num acordo seria o PTB, até agora, aparentemente, a sigla que mais facilidade teria em manter a coesão interna, independente da conjuntura.

Fermentariam discórdias polarizadas na cisão Jango-Ferrari em virtude do receio de parte dos trabalhistas diante da "campanha de renovação" endossada pelo candidato à vicepresidência (BENEVIDES, 1979, p. 125). A falta de consenso se estenderia por toda a administração Goulart, quando ao menos três alas do PTB, com ramificações na Câmara dos Deputados, contestariam o chefe do Executivo. Uma vertente "radical" (representada por Almino Afonso, Miguel Arrais, Leonel Brizola e Neiva Moreira, entre outros), uma corrente "fisiológica" (encampada por Parsifal Barroso, Ivete Vargas, Clemens Sampaio, Batista Ramos e Fernando Nóbrega) e uma ala dos "teóricos" (reunindo nomes como Fernando Ferrari, Santiago Dantas e Lúcio Bittencourt, para citar alguns) se ergueriam em oposição aberta contra o dirigente do país (BENEVIDES, 1979, p. 131).

Tal episódio constituiria, porém, o único caso capaz de ter reflexos maiores sob a coesão da bancada federal - ao menos de acordo com a literatura. Isto porque, apesar das lideranças regionais da sigla normalmente entrarem em conflito com os líderes pessedistas locais, a rivalidade seria resolvida internamente para não abalar a aliança das legendas a nível nacional (Ibid, cap. III).

Discórdias ideológicas e eleitoreiras fizeram do estado de São Paulo um microcosmo, por excelência, das intrigas observadas pelos rachas dos grandes partidos nacionais em virtude dos mesmos inputs. A diferença era que o PSP, inexpressivo nas demais unidades subnacionais, dominava o cenário político paulista, se apropriando da fragilidade do PSD regional, da debilidade da UDN local e da baixa, porém estratégica, organização petebista em São Paulo, para estabelecer seu poder e garantir um papel de protagonismo.

Como no cenário político federal, também no âmbito paulista o sistema partidário se orientava em torno da relação das legendas com Vargas. Foi o próprio Getúlio que viabilizou 
a ascensão do adhemarismo, ao designar como interventor de São Paulo uma figura hábil e carismática, capaz de administrar a máquina pública nos moldes populistas a ponto de conquistar as massas e imperar, por muito tempo, no imaginário dos eleitores, suplantando os adversários - muito embora esse não fosse o desejo do então ditador ${ }^{22}$. Por ironia do destino, ao infortúnio acaso calhou perfeitamente o seu desinteresse pelos trabalhistas - agremiação fundada por ele mesmo -, que contribuiria para elevar as dificuldades enfrentadas na seção paulista, cuja estruturação regional era bloqueada, com freqüência, pela direção nacional petebista, receosa diante da possibilidade do PTB de São Paulo fugir ao seu controle dada a presença maciça do operariado nesse estado (SAMPAIO, 1982, p. 77).

As negociações entre Adhemar e os pessedistas provocariam freqüentes cisões no interior do PSD. Na campanha intervencionista, durante a disputa à vice-governança nas eleições de 1947 e na corrida presidencial de 1950, tais aproximações apenas enfraqueceriam o maior partido da democracia populista, cujos "rachas" internos, motivados pela falta de consenso em torno das vantagens de uma aliança com Barros, suplantariam de vez as chances da legenda se fortalecer em São Paulo (Ibid., cap. IV).

O mesmo se faz válido para o PTB. As tentativas de conformação encampadas ora pela ala borghista ${ }^{23}$, ora pela ala anti-borghista com o governo de Barros se mostrou uma fórmula desfavorável para o futuro político da seção paulista do trabalhismo. A própria aliança entre pessepistas e petebistas, apesar de se fazer constante no estado e encerrar um alto rendimento eleitoral, se revelaria extremamente conflituosa, uma vez que ambos

\footnotetext{
${ }^{22}$ Segundo Sampaio (1982, p. 41), Vargas teria nomeado Adhemar para o cargo por sua aparente adequação à estratégia política que aquele adotava com as oligarquias estaduais. Sem contrariá-las frontalmente, tratava-se de escolher um membro de pequena expressão em seu seio e capaz, portanto, de se submeter mais facilmente ao controle pessoal do chefe do Estado Novo.Todavia, Getúlio logo se conscientizaria de seu erro: Sem dúvida, Adhemar foi elemento capaz de neutralizar, em certa medida, as lideranças perrepistas tradicionais [o objetivo da sua designação], mas o fez no sentido de estabelecer sua própria liderança no estado. E mais, esta liderança adquiriu contornos de um prestígio popular que o levaria a despertar a desconfiança de Vargas.

${ }^{23}$ Expulso do PTB em março de 1947, Hugo Borghi deixou vários adeptos na agremiação, mesmo após ingressar no PTN, legenda que lança sua candidatura ao governo do estado. Desprestigiado por Adhemar, "que preferiu negociar com a ala mais fiel à orientação getulista", o grupo "borghista" passa para a oposição. No entanto, Borghi se reaproximaria de Adhemar tão logo o PTB retirasse seu apoio ao governador, que o nomearia para a Secretaria da Agricultura em 1948 (Cf. Sampaio, 1982, p. 58, nota 2).
} 
disputavam o mesmo espaço (Ibid.). Afinal, as possibilidades de enquadramento políticopartidário, por parte do PSP, do potencial representado pelas massas urbanas esbarram com a concorrência do PTB, cuja base organizacional era a estrutura sindical e previdenciária controlada pelo Ministério do Trabalho.

Embora nunca tenha se defrontado com o problema da acomodação dos interesses regionais, ao contrário do que ocorria com as siglas realmente organizadas em nível nacional, o PSP tampouco se revelou exemplo de coesão partidária, mesmo na sua seção principal. Até os representantes paulistas da agremiação dividiram-se em relação à candidatura de Adhemar no pleito de 1950, sobretudo diante da diminuta probabilidade de êxito, dado o peso meramente estadual do pessepismo.

Fechando esse mosaico, o que importa notar é a aparente origem comum de todas as cisões partidárias então retratadas, qual seja, o desacordo entre as seções regionais, que gozavam de relativa autonomia, frente ao cálculo político, tanto eleitoral quanto parlamentar, a ser seguido pelo partido. Muito se afirma sobre o poder local, muito se alega em favor da relevância do estudo das clivagens territoriais para o entendimento da política brasileira durante a democracia populista. Existe mesmo um apelo para que novos exames considerem devidamente o papel das regiões e dos estados ante a política central, justamente por formarem subsistemas de poder, independentemente de serem reconhecidos como tais dentro de um sistema de governo $^{24}$. Falta, porém, comprovação de que a coesão das legendas à época, que já se sabe ser menor, se alterasse segundo a agência das facções, embora se sugira o tempo todo que aquele era o cenário da sua atuação, e que os presidentes só conseguissem aprovar policy relevante em coalizões ad hoc, negociando votos com a oposição. No próximo capítulo, apresento uma alternativa para se testar o faccionalismo a partir do exame da fase final do processo de tomada de decisão - as votações em plenário.

\footnotetext{
${ }^{24}$ É o pedido de Souza (2006, p. 7).
} 


\section{CAPítulo 2 - O processo deliberativo em 46}

Os especialistas partilham, sem exceção, a ênfase à descentralização do decisionmaking no pré-64. Assume-se a dispersão do poder na Câmara dos Deputados, sobretudo em função da inexistência do Colégio de Líderes - cuja institucionalização ocorreu apenas com a promulgação do Regimento Interno da Casa (RICD), de 1989 - como expressão do papel secundário das lideranças, que se revelariam incapazes tanto de centralizar o processo decisório quanto de coordenar suas respectivas bancadas (AMORIM NETO, SANTOS, 2001; SANTOS, F., 2002; FIGUEIREDO, LIMONGI, 1998).

Todavia, a própria dinâmica de votação observada na democracia populista encerra dispositivos que poderiam acionar a mobilização de divisões intrapartidárias, em que pese a possibilidade de facções, bem como as coalizões, se reunirem ad hoc. Neste capítulo, demonstro que um dispositivo regimental inexistente na atualidade - a verificação de votação por bancadas - facultou ao governo e até mesmo à oposição o controle, em certa medida, do rumo das deliberações na Casa, pela observação dos seus pares em resultados parciais, atenuando o efeito-informação de Riker (1962), ou melhor, o desconhecimento da força relativa da base de apoio ao presidente no Congresso. Deste modo, tanto governo e oposição quanto partidos e suas possíveis dissidências internas conseguiam testar a adesão do plenário à matéria em apreço, podendo calcular, durante a votação, a melhor estratégia a ser traçada e, no limite, se reacomodarem, em momentos críticos, a fim de reverter um quadro desfavorável, onde a derrota parecia certa, para um saldo satisfatório. 


\subsection{Os mecanismos decisórios}

Completando o turno regimental da discussão, a votação das proposições examinadas na Câmara Federal durante a democracia populista podia se dar por três processos distintos: o simbólico, o nominal e o de escrutínio secreto. Salvo a existência de disposição constitucional em contrário, já descritas, as deliberações eram tomadas por maioria de votos, presente a maior parte dos membros da Casa. Portanto, as decisões ocorriam pelos mesmos processos atualmente em voga, não fosse a especificidade da verificação de votação ${ }^{25}$.

De fato, a votação secreta seria a mais rara, tal como se observa hoje. Nem mesmo a variação dos limites de abrangência e formas de solicitação deste mecanismo decisório, predominantemente reservado aos casos previstos na Constituição - a saber: I) a decisão sobre autorização de prisão de deputado ou formação de culpa, no caso de crime inafiançável, ou sobre licença para processo criminal; II) o julgamento das contas do presidente da República; III) a apreciação de veto presidencial; IV) a deliberação de proposta de decretação de estado de sítio e sobre a V) suspensão da imunidade dos membros do Congresso Nacional, cuja liberdade se torne incompatível com a defesa da nação ${ }^{26}$ - instigaria o aumento de requerimentos solicitando deliberações secretas ${ }^{27}$.

\footnotetext{
${ }^{25}$ A Res. n 10, de 1947, ainda aludia ao processo automático, a ser utilizado quando a Câmara dispusesse da aparelhagem necessária - era a referência ao painel eletrônico, que seria implantado apenas em 1980. A menção desapareceria do texto regimental com a publicação da Res. nº. 34, de 1949.

${ }^{26}$ Cf. art. 43 da Carta de 1946.

${ }^{27}$ A Res. no. 10, de 1947, previa escrutínios secretos para todos os projetos que o terço dos deputados preferisse assim deliberar, além dos casos previstos na legislação (art. 119, §11). A perda de mandato parlamentar era outra proposição que a Res. no. 34, de 1949, julgava interessante não ter votação divulgada publicamente (art. 137, item III). Concordando sobre o caso de perda de mandato, a Res. $n^{\circ} .582$, de 1955, frisava a proibição da votação por escrutínio secreto para matéria em regime de urgência, salvo determinação constitucional em contrário (art. $\left.146, \S 5^{\circ}\right)$.

Quanto à forma de solicitação, se estabelece a necessidade de apresentação de um requerimento subscrito pelo terço dos deputados (Res. no ${ }^{\circ}$. 10, de 1947 e 34, de 1949). Seria ainda apontada como prerrogativa exclusiva dos líderes partidários (Res. $\mathrm{n}^{\circ}$. 295, de 1953) ou como pedido concedido tanto a requerimento das lideranças quanto aos subscritos por 25 deputados (Res. $\mathrm{n}^{\circ}$ 582, de 1955).

Aproveito a nota para lembrar que a referência provisória para os trabalhos parlamentares desde a publicação da Carta de 1946 foi o regimento interno elaborado durante a própria constituinte até a aprovação da Res. $\mathrm{n}^{\circ}$. 10, de 1947, que apresenta a primeira revisão dos procedimentos legislativos deliberada pelos representantes após a restauração liberal e a definição do Congresso ordinário. Por este motivo, a última será usada como referência
} 
Como o próprio nome sugere, o escrutínio secreto preservava o resultado da votação, cujo saldo entrava para os anais da Câmara apenas nas vagas categorias "não houve votação", "aprovada" ou "adiada" - tal qual acontece na atualidade. Logo, era e ainda é uma forma de salvaguardar as posições assumidas pelos deputados, protegendo-os de futuras ameaças pela conseqüência de seus atos (CARVALLHO, 1973, p. 195-96).

Em certa medida, a votação simbólica também resguardava o anonimato dos parlamentares, sendo registrado na publicação oficial da Casa apenas a posição sufragada pelo plenário, de modo a cumprir a mesma função que lhe atribui o RICD vigente na atualidade. Meio de deliberação mais freqüente nas duas experiências democráticas, ela se inicia, em tese, com o intercurso do presidente da Casa ao plenário, convidando os deputados contrários a proposição em debate a se levantarem, enquanto os favoráveis permanecem sentados posição supostamente inicial de todos os presentes -, proclamando em seguida o resultado manifesto dos votos ${ }^{28}$. Em tese.

Normalmente, a praxe era anunciar o objeto em deliberação, seguido de seu resultado.

Observe:

O SR. PRESIDENTE - Em votação o seguinte REQUERIMENTO

Requeiro a inclusão na ordem do dia do projeto 344 de 1949 que federaliza as Escolas de Medicina e Engenharia de Recife e Medicina de Belo Horizonte, na forma do art. $151 \S 3^{\circ}$ e art. 153 do Regimento.

Sala de Sessões, 17 de novembro de 1949 - Manoel Novaes.

Aprovado.

(Diário da Câmara dos Deputados, 22 de novembro de 1949, p. D014050146.TIF, col. 3).

básica para a discussão que segue, já que os regimentos posteriormente aprovados decorreriam de resoluções, justificando a menção das normas procedurais situadas na resolução destacada enquanto regras regimentais vigente à época, conforme ocorrerá em várias passagens do presente trabalho.

${ }^{28}$ Dentre todos os regimentos e resoluções publicados entre 1946 e 1964, apenas a Res. $n^{\circ}$ 10, de 1947 divergiria no que diz respeito exclusivamente ao método de votação, invertendo a expressão corporal ao estabelecer que os deputados favoráveis a matéria em votação devessem se levantar para sinalizar sua adesão (art. $119, \S 2^{\circ}$ ). Já na próxima resolução de peso aprovada pela Câmara, se decidiria pela adoção do preceito diametralmente oposto, qual seja, a manifestação física dos contrários à proposição em trâmite (Res. nº. 34, de 1949, art. 135), não havendo mais alterações neste quesito. 
Nada absurdo, todavia. Aparentemente, o diretor dos trabalhos da Câmara tendia a ficar mais 'preso' à letra do regimento quanto maior a complexidade da decisão a ser tomada, para evitar a confusão dos deputados sobre o que estava em votação bem como no que diz respeito ao próprio significado de se manifestar a favor ou contra ao objeto colocado a votos pela Mesa, tal como ocorre hoje. Ainda que o hábito ilustrado acima pudesse aprazer o governo, em face da possibilidade da Mesa acelerar, por essa via, a apreciação de matérias do interesse do Executivo exatamente para comprometer as articulações de veto tensionadas no seio da oposição, isto não configuraria uma peculiaridade do pré-64. Basta nos lembrarmos da conduta desenfreada de Luís Eduardo (PFL/BA) sob a presidência da Câmara dos Deputados no biênio 1995-1997, famoso por agilizar a passagem da agenda presidencial não somente procedendo de maneira análoga ao anúncio da votação ilustrado acima, mas ignorando, inescrupulosamente, pedidos de verificação do resultado proclamado, assegurados regimentalmente aos parlamentares presentes na Casa tão logo a preferência dominante lhes fosse comunicada.

A grande diferença entre os procedimentos de deliberação adotados em cada experiência democrática, até então sonegada pela literatura, diz precisamente respeito ao pedido de verificação da votação, facultado na existência de dúvida quanto ao saldo divulgado pelo presidente da sessão. No período 46-64, o processo de checagem dos votos não seguia diretamente à votação nominal, como se faz nos dias de hoje. Existia uma verificação de quorum preliminar, que só redundava em chamada nominal na ausência de número legal.

Qualquer deputado poderia questionar o saldo da votação sinalizado pela Mesa. Até a publicação da Res. $n^{\circ} .582$, de 1955, o pedido de verificação era imediatamente acolhido, não sendo necessário apoiamento mínimo para ser deferido. Já a partir da sanção desse texto, a 
checagem do resultado passou a depender da adesão de pelo menos 20 deputados para ser $\operatorname{assegurada}^{29}$.

Basicamente, a verificação consistia na contagem dos votos, que se faria por bancadas, isto é, por filas de poltronas do recinto, uma a $\mathrm{uma}^{30}$. O presidente deveria convidar os deputados favoráveis à matéria em debate a se levantarem, enquanto o primeiro secretário anunciaria, em voz alta, o resultado parcial obtido em cada bancada ou fileira, à medida que se fizesse a checagem. Da mesma forma se procederia na contagem dos votos contra. Finalmente, o resultado total apurado seria anunciado (Res. no. 10, de 1947, art. 129, § 20 $)^{31}$.

É o que se passa na votação de uma emenda ao Projeto de Decreto Legislativo $n^{\circ} 45$ C/1956, que concede anistia aos que respondem processos políticos, selecionado como nosso suporte para dar "corpo" à dinâmica descrita acima. Acompanhe o registro de sua deliberação no Diário:

\section{O SR. PRESIDENTE:}

Os senhores que aprovam a emenda $\mathrm{n}^{\circ} 3$, queiram ficar como estão (Pausa). Rejeitada.

O SR. AARAO STEINBRUCH:

(Pela ordem) requer verificação de votação.

O SR. PRESIDENTE:

Peço que se levantem os Senhores Deputados que apóiam a verificação. (Pausa).

Está concedida.

Procedendo-se à verificação, por bancadas, reconhece-se terem votado a favor: 39 Srs. Deputados e contra 130, total 169, com o Presidente, 170.

O SR. PRESIDENTE - Está rejeitada a emenda $\mathrm{n}^{\circ} 3$.

(Diário da Câmara dos Deputados, 23 de maio de 1956, p. D012290363.TIF, col. 1-2).

\footnotetext{
${ }^{29}$ Eis a determinação do art. $140, \S 3^{\circ}$, do referido texto. Ao longo do período, novas atualizações no Regimento são ratificadas, afetando o procedimento de votação. Todas as mudanças que impactam o método de deliberação podem ser consultadas no Anexo B - Alterações regimentais no processo de votação, à p. 134.

${ }^{30}$ É importante frisar que a norma procedural então em voga associa o termo "verificação por bancadas" exclusivamente a fileiras de assentos no plenário da Câmara dos Deputados, e não a bancadas parlamentares enquanto grupos políticos com interesses em comum, por exemplo. A palavra tem apelo físico, não político. Como, na prática, tal checagem equivalia à avaliação da existência de quorum legal para deliberação, passo a chamar o procedimento daqui por diante de "verificação de quorum", à exceção dos trechos de documentos oficiais eventualmente transcritos, seções onde preservo a definição oficial, respeitando a reprodução fidedigna dos textos.

${ }^{31}$ A praxe de se renovar a votação simbólica antes de se prosseguir à verificação de quorum, que só se efetivaria caso o requerente insistisse em seu pedido, não vingou. Introduzida pela Res. nº. 34, de 1949, a opção cairia em desuso logo na revisão regimental que a sucedeu, em 1955, como indica o Anexo B, na p. 134. De todo modo, o Anexo $C$ reproduz, a título de ilustração, um caso de verificação de votação precedida de renovação da votação simbólica (vide p. 135).
} 
Neste exemplo, o número de votos manifestos ultrapassou o quorum mínimo, necessário à aprovação da emenda oferecida a projeto de lei ordinária, então fixado em 164 $\operatorname{votantes}^{32}$. A verificação requerida, portanto, foi o bastante para se conhecer o saldo final da deliberação, então concluída. Isto porque, mesmo que algum deputado continuasse a se dar por não convencido sobre as parciais divulgadas, era vedava a prática de mais de uma verificação para cada votação (Res. nº 10, de 1947, art. 129, § 3º).

Caso, porém, a votação indicasse ausência de número, o regimento determinava a realização da chamada dos deputados, que se faria como votação nominal da matéria em deliberação, salvo se, pelo adiantado da hora, ou por ser visível a falta de quorum, o presidente a julgasse dispensável ${ }^{33}$ - protelando a decisão para a ordem do dia seguinte, mas sem nenhuma garantia de recolocá-la, de fato, a votos.

Endossada a opção pelo método nominal, os deputados seriam chamados, em voz alta, pelo $1^{\circ}$ Secretário, respondendo sim, ou não, conforme fossem a favor ou contra o que se estivesse votando (Ibid.). Dois outros secretários tomariam notas dos parlamentares que votassem num, ou noutro sentido, proclamando em voz alta o resultado da votação à medida que o $1^{\circ}$ Secretário fizesse a chamada $\left(\S 4^{\circ}\right)$. Uma vez encerrada a votação, o presidente anunciaria o resultado final, mandando ler em seguida os nomes dos que votaram sim e os dos que votaram não $\left(\S 5^{\circ}\right)$ - daí se denominar o processo de votação nominal.

\footnotetext{
${ }^{32}$ Esse patamar varia segundo o número de cadeiras preenchido em cada legislatura, conforme a legislação eleitoral. A tabela reproduz o número de deputados eleitos em cada uma das cinco legislaturas conformadas no pré-64, indicando o quorum em casos de deliberações decididas por maioria simples.
}

\begin{tabular}{c|c|c|c|c} 
Legislatura & Início & Término & Cadeiras & $\begin{array}{c}\text { Quorum } \\
\text { Mínimo }\end{array}$ \\
\hline 38 & $01 / 02 / 1946$ & $31 / 01 / 1951$ & 286 & 144 \\
\hline 39 & $01 / 02 / 1951$ & $31 / 01 / 1955$ & 304 & 153 \\
\hline 40 & $01 / 02 / 1955$ & $31 / 01 / 1959$ & 326 & 164 \\
\hline 41 & $01 / 02 / 1959$ & $31 / 01 / 1963$ & 326 & 164 \\
\hline 42 & $01 / 02 / 1963$ & $31 / 01 / 1967$ & 409 & 205
\end{tabular}

${ }^{33}$ Cf. Res. no 10 , de 1947 , art. $129, \S 4^{\circ}$. 
Para ilustrar tal desfecho, recupero a votação de um substitutivo oferecido ao PL. $\mathrm{n}^{\mathbf{o}}$ 3457-C/1953, que proibia a exportação de minério de manganês extraído em algumas jazidas de Minas Gerais. Vejamos:

O SR. PRESIDENTE:

Os Srs. que aprovam o Substitutivo queiram ficar como estão (Pausa).

Aprovado.

O SR. JOÃO CABANAS:

(Pela ordem) requer verificação de votação.

Feita a nova votação simbólica é dado como Aprovado.

O SR. JOÃO CABANAS:

(Pela ordem) insiste na verificação por bancadas. Procedendo-se a verificação da votação por bancadas, reconhece-se terem votado a favor 38 Srs. Deputados e contra, 2, total 40, com o Sr. Presidente, 41.

\section{O SR. PRESIDENTE:}

Não há número.
Vai-se proceder à chamada e conseqüente votação nominal.

Os Srs. Deputados que votaram a favor do Substitutivo responderão Sim e os que votaram contra responderão Não.

O SR. RUY SANTOS:

$3^{\circ}$ Secretário, servindo de $1^{\circ}$, procede a chamada nominal.

\section{O SR. PRESIDENTE:}

Responderão à chamada nominal e votaram 184 Srs. Deputados, sendo 173 SIM; e 11, NÃO.

Está aprovado o Substitutivo.

Votarão Sim os Srs. Deputados:

Amazonas:

Antonio Maia - PSD

Jayme Araújo - UDN

[...]

(Diário da Câmara dos Deputados, 13 de novembro de 1953, p. D013320675.TIF- D013320676.TIF).

Dessa vez, a verificação de quorum indicou número muito inferior ao mínimo legal em 1953, fixado em 153 votos. O presidente resolveu dar continuidade à deliberação, passando ao método nominal, que acabou validando a votação, consumada a participação de 184 deputados no processo. No entanto, o diretor dos trabalhos da Câmara poderia simplesmente ter dispensado a chamada, alegando o descabimento de se prosseguir numa deliberação muito provavelmente pouco promissora em termos de resultado concreto, dada a aparente falta de número em plenário revelada pela checagem de quorum pregressa. Se a matéria tivesse entrado em pauta ao final da sessão, ainda seria passível ao presidente recorrer ao argumento do adiantado da hora para se escusar de afiançar o transcorrer desse longo e custoso processo nominal ${ }^{34}$. Logo, a decisão política substantiva que se conformaria no legislativo federal de 46-64 dependia, a princípio, da predisposição de um único ator, capaz de fazer uso da própria proteção regimental para subjugar o decision-making aos auspícios de suas paixões pessoais ou aos negócios de quem ele defendesse.

\footnotetext{
${ }^{34}$ No Anexo D, são reproduzidas votações que tomaram os referidos rumos alternativos. Vide p. 136.
} 
Na experiência atual, a votação nominal também se origina destas três situações: verificação de votação, deliberação sobre propostas de emenda constitucional e requerimento de algum deputado. Contudo, ela constitui a única fase de decisão a expor a posição do parlamentar, já que hoje inexiste qualquer intermediação entre o método nominal e a votação simbólica, realizada em bloco, coletivamente. Em contrapartida, ao introduzir a verificação de quorum, realizada por fileiras de poltronas no plenário, o RICD em voga no pré-64 garantia o conhecimento de todos os votos individuais manifestos a todos os presentes ao escrutínio numa etapa que assumiria, com freqüência, rótulo preliminar. Sem atingir número legal, um montante de verificações de quorum serviria como termômetro do plenário, sinalizando as preferências dos legisladores em parciais reveladoras tanto para líderes partidários acompanharem o comportamento de seus respectivos quadros - e as cisões neles desenhadas quanto para o governo avaliar a conduta e força relativa da sua base de apoio, confrontando-a com a mobilização aparente da oposição. Estava posta, assim, a exposição dos deputados, que subtraía dos representantes o conforto inerente às decisões simbólicas, de teor agregado, capazes de "camuflar" o voto dado por todos e, na prática, ter efeito semelhante ao manto protetor "estendido" pelas votações secretas.

A despeito dessa nítida correspondência, em termos políticos, entre as checagens de quorum e a chamada nominal, reconhecidamente apontada pela literatura dedicada ao exame do momento presente como o mecanismo público de deliberação por excelência, não houve qualquer esforço até hoje voltado à avaliação do impacto substantivo das averiguações de número legal deferidas pela Mesa Diretora na República de 46. Nem mesmo a principal defesa no emprego das nominais enquanto unidade analítica, formulada por Carvalho (1973, 1977), que estudou o período JK, observou a importância das verificações de quorum enquanto meio de conflito na Câmara dos Deputados. 
Não se pode negar a contribuição da autora, que apontou o significado expressivo das votações nominais, capazes de testarem, por assim dizer, os compromissos assumidos pelos congressistas, sejam acordos de natureza eleitoral ou partidária ${ }^{35}$. Destacando a discrição típica da votação simbólica, na qual o voto de cada representante mescla-se com os de outros e apenas o resultado - aprovado ou rejeitado - é inscrito nos Anais da Câmara, Carvalho destacou a predominância de decisões sobre questões mais consensuais por esta via, apontando o peso das deliberações nominais para se filtrar a maior parte dos assuntos conflitantes. Tornando compulsoriamente públicas as preferências de cada parlamentar, elas aumentariam muito o preço das decisões por maioria, uma vez que revelariam tanto o conflito quanto o consenso público entre a situação e a oposição. Isto porque a votação nominal de uma matéria permitiria à situação averiguar as posições assumidas pelos seus membros ante as propostas da agenda do Executivo, ao passo que as lideranças partidárias poderiam visualizar o comportamento das suas respectivas bancadas. Ao eleitor, por sua vez, se tornaria facultativo o controle democrático (CARVALHO, 1973).

Todavia, as verificações de quorum atendiam a duas destas três possibilidades. Ainda que o processo de decisão ficasse restrito ao conhecimento dos atores presentes à arena legislativa - impedindo a avaliação do eleitorado sobre as atitudes individuais de seus representantes -, os líderes podiam acompanhar claramente a adesão ou não dos seus respectivos quadros aos interesses partidários, da mesma forma que ficava viável ao governo e à oposição observar o comportamento do plenário (analisando tanto a disciplina interna quanto os votos exteriores às suas plataformas).

Na prática, portanto, a contagem dos votos por fileiras de poltronas no plenário, da forma como se dava, aumentava o custo político da decisão, deixando o parlamentar numa

\footnotetext{
${ }^{35}$ Nas suas palavras, Ao tornar as decisões públicas, permite-se testar até que ponto os compromissos assumidos se mantêm. Expressa assim um conflito entre dois estilos de representação: o do mandatário que segue as instruções daqueles que o elegeram e o do autônomo que segue a si próprio. Dependendo de quão importante aquela questão é para o eleitorado e da relação que o deputado mantém com ele, a votação nominal pode mudar ou não as posições assumidas anteriormente (CARVALHO, 1973, p. 196).
} 
situação difícil - e muito semelhante à enfrentada na votação nominal. Ambas expunham os deputados entre si, de modo que qualquer checagem da decisão simbólica acabava invariavelmente refletindo o jogo de forças no plenário, expondo dissidências intra e interpartidárias.

Supondo a prevalência do facciosismo durante a democracia populista, a regulação regimental em torno da verificação de quorum assume, conseqüentemente, caráter investigativo destacado. Isto porque o retrato do período, da forma como foi esboçado pela literatura, enfatiza a limitação do governo em calcular perfeitamente o tamanho de sua real coalizão de apoio no Congresso em função da baixa coesão partidária, típica em 46-64. Em tese, essa dificuldade nata de se estimar a força relativa dos parceiros do presidente no parlamento durante as negociações responsáveis pela montagem de uma base de apoio legislativo, cunhada por Riker (1962) como efeito-informação, motivaria os assédios do Executivo à oposição, aproveitando-se das divisões intrapartidárias existentes em seu seio para angariar as cabeças faltantes e reunir um grupo mínimo, capaz de aprovar as medidas pretendidas. Acredito no potencial da checagem de número como instrumento tático, à disposição dos atores envolvidos, para a medição do poder de cada bancada no embate em plenário. Afinal, a verificação de quorum viabilizou aos parlamentares o acompanhamento do rumo das deliberações que ali tinham lugar pela observação dos seus pares em resultados parciais. Por conta dela, situação e oposição, legendas e suas prováveis cisões internas conseguiam avaliar a adesão do plenário à matéria em exame, podendo traçar, durante o próprio desenrolar da votação, a estratégia aparentemente mais conveniente, inclusive a reacomodação dos deputados se necessário fosse, em prol dos saldos almejados.

Estudos sobre a experiência norte-americana denunciam a transação de votos justamente no desenrolar das deliberações. King e Zeckhauser (2001) demonstram a capacidade dos líderes coordenarem a ação dos parlamentares, sobretudo em votações 
apertadas. O trabalho evidencia a existência de uma margem de votos negociáveis, que seriam objeto de especial atenção quando o resultado da deliberação se asseverasse demasiado incerto. Nas decisões mais importantes e críticas, vitórias estreitas seriam muito mais freqüentes do que perdas estreitas. Além disso, em questões-chave, as lideranças amargariam derrotas por margens maiores frente à folga verificada em vitórias sobre matérias de igual teor. Saiegh (2011) ratifica a tese, apontando a postura eventual de alguns deputados, que ficariam observando as parciais da votação, manifestando-se apenas momentos antes da preferência majoritária ser definida, ou mesmo retificando o voto já expresso ao início da deliberação, caso fosse assim acertado no decorrer do processo. Nestes termos, as variações nas taxas de produção legislativa decorreriam das diferenças de incerteza sob o plenário, e não de apoio partidário. Dito de outro modo: o sucesso legislativo dependeria da previsibilidade do comportamento de legisladores com direito a voto e da viabilidade da compra de votos.

Nesta perspectiva, o controle exercido pelo presidente da Mesa sobre o decision making na República de 46 torna-se uma proxy de demasiada relevância na crítica da díade faccionalismo-governabilidade. É importante mensurar a discricionariedade do diretor dos trabalhos legislativos, já que grandes eram os motivos para a sua atuação se orientar em consonância aos interesses da maioria, sabiamente a grande controladora deste posto estratégico.

Não por acaso, inclusive, Lúcia Hippólito (1985) pode ter se esquecido de citar a passagem de Flores da Cunha no mais alto cargo da Câmara dos Deputados ao frisar que todos os presidentes da Mesa Diretora entre 1946 até 1964 teriam sido pessedistas: Fernando Melo Viana (presidente da Casa à época da Assembléia Nacional Constituinte), Samuel Duarte (1947-1948), Cirilo Junior (1949-1950), Nereu Ramos (1951-1954), Carlos Luz (1954-1955), Ulisses Guimarães (1956-1958) e Ranieri Mazzili (1958-1964) - representantes, portanto, do partido que deteve a maioria das cadeiras em todas as legislaturas da democracia 
populista (HIPPÓLITO, 1985, p. 68, nota 22). Afinal, Cunha deixaria a UDN, pela qual assegurava a própria estada na Casa desde a Constituinte de 1946, pouco antes de assumir a direção dos trabalhos legislativos no plenário, em 1955, dada a substituição de Carlos Luz alçado à chefia do Poder Executivo devido ao afastamento de Café Filho do governo -, declarando-se sem partido até dois anos após deixar a referida posição de destaque, em 1956. Gaúcho e influente em seu estado, Flores da Cunha não representava, exatamente, uma descontinuidade na hegemonia do PSD, pela sua condição de independência frente à cúpula udenista. Constituía, antes, uma ótima escolha aos olhos do maior partido do pré-64, enfraquecido que era o pessedismo no Rio Grande do Sul.

Desse modo, a ampla margem de independência do presidente da Câmara Federal no desenrolar das votações em plenário emerge como verdadeira delegação da vontade da maioria dos legisladores. Não fosse assim, os artigos regimentais que asseguravam ao diretor das sessões na Câmara ampla margem de manobra na condução das deliberações na Casa certamente seriam alterados, a fim de deslegitimar as ações discricionárias então garantidas ao arbítrio daquele ator pelo próprio texto norteador dos trabalhos legislativos - o regimento interno. Mantidas inalteradas as referidas regras por todo o período, dispensa-se mesmo o contrafactual para se depreender que, do modo como a tomada de decisão estava institucionalizada, a liberdade do regente da Mesa não se afigurava acima dos partidos representados em plenário, mas constituía uma "concessão" das legendas ao dirigente da dinâmica legislativa no âmbito da Câmara dos Deputados.

Isto não equivale a dizer que o decision making fosse incólume a disputas naquela época. Pelo contrário: a conjuntura política e a organização institucional faziam da democracia populista o retrato de um campo minado. No jogo entre situação e oposição, partidos e facções, a simpatia da Mesa era o "coringa". O conflito poderia até ser iniciado, com a contestação do resultado anunciado, mas a maioria - de certa forma, sempre 
conservando a presidência da Casa -, contava com suas cartas "na manga". Coordenando a fase final do processo deliberativo, o presidente das sessões no plenário era capaz de fazer uma aparente ameaçadora checagem de votação redundar num saldo favorável, em prol do governo. Na incapacidade de negar petições do gênero ${ }^{36}$, sua margem de manobra era favorecida pela própria observação das parciais divulgadas pelas verificações de quorum, que funcionavam como verdadeiros "placares" ad hoc, boas referências para se calcular o melhor timming à apreciação das proposições prontas para votação - cuja ordenação ficava, por determinação regimental, a encargo da Mesa.

A figura 1.1 sintetiza as possíveis rotas do processo decisório, identificando ainda as demais origens regimentais da votação nominal, inclusive aplicada às propostas de emenda constitucional (art. 141, $\S 18^{\circ}$ ) e às matérias sobre as quais o plenário assim decidisse deliberar, aprovando um requerimento escrito, de autoria de qualquer deputado, neste sentido (art. 253). A partir da outorga da Lei nº. 1079, de 10 de abril de 1950, vulga Lei dos Crimes de Responsabilidade ${ }^{37}$, toda decisão sobre atos do Presidente da República condenados por essa norma invariavelmente passa a valer somente por deliberação nominal. Com a Resolução nº. 71, de 1962, tal mecanismo começa a reger as deliberações sobre as moções de confiança (art. 99, $\S 2^{\circ}$ ) e as indicações para a presidência do Conselho de Ministros (art. 105), que só poderiam ser votadas nominalmente ${ }^{38}$.

\footnotetext{
${ }^{36}$ Pelo regimento de 1934 , todo pedido de verificação seria deferido (art. $238, \S 1^{\circ}$ ). A necessidade de apoio ao parlamentar requerente da verificação seria introduzida apenas com a Resolução no 582 , de 1955 , que reclamava a adesão de pelo menos mais 20 deputados para conceder a petição (art. 140, § $3^{\circ}$ ).

${ }^{37}$ A referida norma determina o julgamento das ações do chefe do Executivo que atentam contra a Constituição Federal, e, especialmente, contra: I - A existência da União; II - O livre exercício do Poder Legislativo, do Poder Judiciário e dos poderes constitucionais dos Estados; III - O exercício dos direitos políticos, individuais e sociais; IV - A segurança interna do país; V - A probidade na administração; VI - A lei orçamentária; VII - A guarda e o legal emprego dos dinheiros públicos; VIII - O cumprimento das decisões judiciárias (Constituição, artigo 89).

${ }^{38}$ O quadro 1 é uma reelaboração da ilustração apresentada por Carvalho (1973: 195) sobre a dinâmica da fase de deliberação em plenário nos anos JK. As alterações adaptaram o diagrama às especificidades dos regimentos internos vigentes durante todo o período 46-64, ampliando as possibilidades dos rumos da votação não cobertas no recorte proposto pela autora.
} 


\section{Figura 1.1 - Processo de votação}

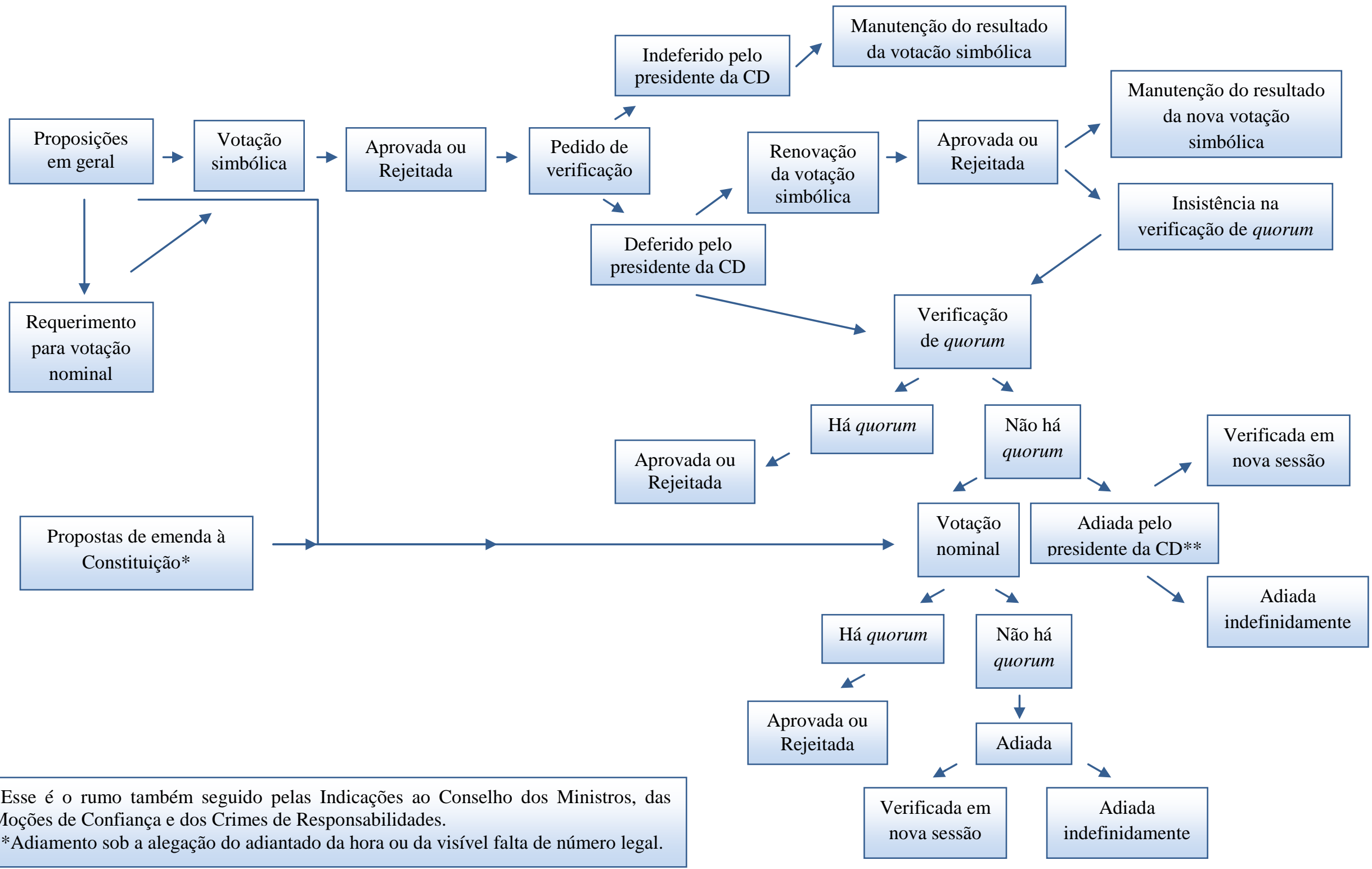


A equivalência entre a verificação de quorum e a chamada nominal no que tange à exposição dos deputados perante seus respectivos líderes e grupos ideológicos torna especialmente interessante o exame dos dois tipos de checagem de votação para o entendimento da dinâmica entre governo e Congresso na democracia populista. Em termos políticos, ambas as formas ampliavam consideravelmente o custo da decisão levada a cabo no plenário. Por este motivo, constituem o foco da análise subseqüente.

\subsection{A distribuição das verificações de votação}

Embora as administrações que se seguiram durante o pré-64 pudessem temer o apoio efetivo de suas respectivas coalizões no parlamento em função das recorrentes querelas intrapartidárias, o governo contava com alternativas para contornar o problema em plenário. Naquela época, o propalado receio do Executivo sobre o grau concreto da ameaça representada pelo comportamento independente dos legisladores à aprovação da agenda presidencial era capaz de mitigar a zona de incerteza e ser materializado ao longo do processo decisório. Através das checagens da decisão simbólica, a disposição das forças no Congresso ficava patente, de modo que o número real de representantes sensíveis aos apelos do programa de trabalho situacionista se fazia conhecido, minimizando o efeito-informação e, por extensão, o risco inerente às estratégias adotadas por este grupo na mira da construção de maiorias em prol da passagem das medidas almejadas.

A tabela 2.1 totaliza os dois tipos de verificação de votação deferidos entre 46 e 64 . Nada menos do que 1729 checagens de decisões primárias foram aceitas pelo presidente da sessão plenária, relativas a 686 matérias de cunho distinto, entre votações de projetos e procedimentos. 
Tabela 2.1 - Distribuição das verificações de votação, por coalizões (1946-1964)*

\begin{tabular}{|l|c|c|c|}
\hline \multicolumn{1}{|c|}{ Coalizão } & $\begin{array}{c}\text { Número total } \\
\text { de Votações }\end{array}$ & $\begin{array}{c}\text { Duraçao da Coalizão } \\
\text { (em meses) }\end{array}$ & $\begin{array}{c}\text { Média de } \\
\text { votações ao mês }\end{array}$ \\
\hline \hline Dutra II & 272 & 42 & 6,5 \\
\hline Dutra III & 36 & 10 & 3,6 \\
\hline Vargas I & 121 & 28 & 4,3 \\
\hline Vargas II & 152 & 12 & 12,7 \\
\hline Vargas III & 11 & 3 & 3,7 \\
\hline Café Filho I & 102 & 5 & 20,4 \\
\hline Café Filho II & 58 & 9 & 6,4 \\
\hline N. Ramos & 62 & 3 & 20,7 \\
\hline JK I & 518 & 36 & 14,4 \\
\hline JK II & 247 & 24 & 10,3 \\
\hline Quadros & 37 & 7 & 5,3 \\
\hline Ranieri Mazzili & 4 & $0 * *$ & - \\
\hline Goulart I & 4 & 1 & 4,0 \\
\hline Goulart II & 65 & 9 & 3,2 \\
\hline Goulart III & 6 & 2 & 1,0 \\
\hline Goulart IV & 4 & 4 & 1,8 \\
\hline Goulart V & 7 & 4 & 3,7 \\
\hline Goulart VI & 22 & 6 & 0,3 \\
\hline Goulart VII & 1 & 3 & - \\
\hline Total & $\mathbf{1 7 2 9}$ & - & 506 \\
\hline
\end{tabular}

*Considera tanto as verificações de votação sobre projetos quanto sobre procedimentos regimentais. **Esta coalizão amargou meros 13 dias de duração.

Fonte: Banco de Dados Legislativos, Cebrap.

Os dados indicam que os deputados tiveram seus votos conhecidos pelos seus pares sobretudo no governo Kubitschek, quando se registra a maior incidência de ambos os mecanismos decisórios, isto é, as checagens de quorum e as deliberações nominais propriamente ditas - nomes distintos para praxes de magnitude quase idêntica. Somente em JK I localizam-se nada menos do que 518 (30,0\%) das 1729 verificações de votação concedidas ao longo de todo o pré-64 ${ }^{39}$. Em números absolutos, as coalizões Dutra II (272),

\footnotetext{
${ }^{39}$ Carvalho (1973) já havia destacado este período. Analisando apenas as votações nominais no mandato JK, a autora notou a maior recorrência desta forma de deliberação nos anos pós-eleitorais (1956 e 1959). A seu ver, isto evidenciaria “o conflito entre ou dentro dos partidos para a 'renumeração' das bases estaduais e locais dos deputados pelo apoio recebido durante o período eleitoral” (CARVALHO, 1973, p. 197, grifo meu).

De fato, mais de um terço das votações com exposição pública dos parlamentares (checagem de quorum e chamada nominal) recai sobre emendas orçamentárias durante a administração JK - 40,3\%, para ser exata (220) -, uma conhecida forma dos congressistas pleitearem a alocação de recursos em favor de seus redutos eleitorais. Tal procedimento ainda é o foco de 76,9\% (70), 41,6\% (32) e 25,2\% (60) das contestações de resultado nos
} 
JK II (247), Vargas I (121) e II (152) e Café Filho I (102) também se destacam pela elevada recorrência desse instrumento regimental, todas com montantes, no mínimo, de ordem centenária. Na contramão, as experiências Ranieri Mazzili, Goulart I, Goulart III, Goulart IV, Goulart V e Goulart VII ganham projeção inversa, com observações abaixo de dez casos cada uma - mais exatamente, encerrando 4, 4, 6, 4, 7 e 1 verificações deferidas, nesta ordem.

Ponderando, porém, o total acumulado em cada coalizão pela sua duração correspondente, em meses, encontram-se escores relativos perturbadores. Surpreende a freqüência com a qual os deputados foram submetidos a deliberações constrangedoras, responsáveis pela revelação individual de seus votos, em composições políticas dissolvidas rapidamente. Em relevo, constam Café Filho I e Nereu Ramos, com médias de verificação de votação consideravelmente altas para o tempo em que vingaram - meros 156 e 80 dias, respectivamente, para ser precisa.

Vale lembrar que ambos foram alçados à chefia do Executivo pelas portas dos fundos, no esteio de uma crise política iniciada com a morte de Vargas e intensificada após falhos conchavos encabeçados pela própria UDN para impedir a posse Juscelino e Goulart, vencedores da corrida presidencial de 1954. Após o suposto suicídio de Getúlio, é seu vice, Café Filho, que assume o comando do Brasil, governando sem base parlamentar sólida, já que Adhemar de Barros o liberaria de compromissos com o PSP pela incapacidade da bancada pessepista respaldar a passagem da sua agenda presidencial no Congresso e, na prática, até os partidos da própria base de apoio consequientemente orquestrada virem a se declarar em posição de independência frente ao seu mandato. Afastando-se por problemas de saúde, repassa-se o cargo a Carlos Luz, diretor dos trabalhos da Câmara dos Deputados naquele momento - e sensível aos apelos udenistas, que pleiteiam o cancelamento dos resultados eleitorais para a sucessão do controle do país sob a alegação de que os eleitos não haviam casos. 
alcançado a maioria absoluta dos votos - muito embora inexistisse cláusula constitucional prevendo tal necessidade para se fazer legítima a investidura nos mais altos cargos da gestão pública.

A partir de então, a oposição principia um demorado cortejo a alguns dos setores mais conservadores das Forças Armadas para armar um boicote, pelas vias legais, a impossibilitar a entrega do poder à díade JK-Jango. Por temor de um levante autoritário, o marechal Teixeira Lott lidera um golpe preventivo, para garantir a posse dos eleitos. Na Câmara, Carlos Luz é declarado impedido de exercer a presidência a 11 de novembro de 1955. Em sua residência, Café Filho, já restabelecido e disposto a retornar ao cargo que lhe era de direito, é feito prisioneiro. Na linha de sucessão imediata ao cargo, Nereu Ramos, à época vice-presidente do Senado Federal, é declarado o novo presidente interino do Brasil, comprometendo-se a assegurar o respeito aos resultados das urnas e empossar JK e João Goulart em janeiro do ano seguinte.

Em vista de toda essa convulsão política, seria bastante plausível conjecturar o empenho da oposição em se aproveitar do cenário de crise que abalava a manutenção da ordem democrática para manipular resultados conforme os seus interesses específicos. Em teoria, ninguém deveria conhecer tão bem o regimento quanto os partidos diametralmente opostos à situação dominante. Afinal, é no texto norteador da conduta a ser seguida em plenário que os oposicionistas buscam formas de ação contrárias ao governo, porém legais. Nestes termos, faz-se razoável a suposição da provável habilidade dos udenistas, na segunda e última administração presidencial da qual tomariam parte, ao menos formalmente, em canalizar os instrumentos antes acionados por eles para embargar o processo decisório a serviço contrário, em benefício próprio, sob a curta experiência de Café Filho à frente da República populista. A UDN poderia mesmo ter se aproveitado da etapa de transição operada por Nereu Ramos para manejar instrumentos regimentais capazes de lhe garantir, até já 
reconduzida ao seu espaço habitual - aquele digno das legendas alheias à coalizão de apoio ao presidente no Congresso - as vitórias almejadas no terreno parlamentar.

Testar ambas as hipóteses requer a análise das autorias dos pedidos de verificação de votação concedidos em 46-64, cujo balanço inicial é delineado no gráfico abaixo.

\section{Gráfico 2.1 - Autoria dos pedidos de verificação concedidos, por grupo partamentar(1946-1964)*}

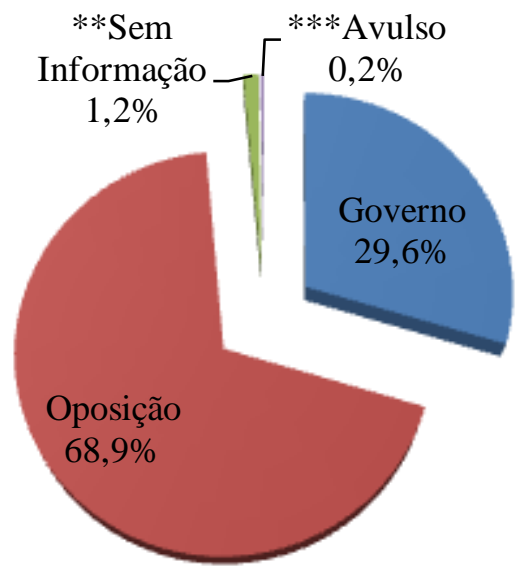

*Desconsidera votações nominais asseguradas regimental ou constitucionalmente. **Sem Informação - Diz respeito às vezes em que o nome do parlamentar autor do pedido de verificação não aparece nos diários da Câmara. ***Avulso - Categoria exclusiva para o governo de Mazzili, que foi meramente transitório, sem a formação de coalizão parlamentar de apoio ao presidente, não sendo possível posicionar a autoria dos pedidos de verificação de votação concedidos à época.

Fonte: Banco de Dados Legislativos, Cebrap.

Conforme a ilustração aponta, realmente se constata o predomínio de iniciativa da oposição, responsável por quase $70 \%$ dos pedidos de verificação de votação concedidos durante todo o pré-64. A princípio, o quadro revelado corresponde ao esperado, uma vez considerada a usual praxe dos oposicionistas em empregar diversos mecanismos procedimentais tanto para comprometer o ritmo decisório no parlamento como para reafirmar as próprias bases programáticas perante o eleitorado, embora tenha ciência da impossibilidade de contar com o endosso do plenário na aprovação das causas em questão ${ }^{40}$.

\footnotetext{
${ }^{40}$ Para enveredar na discussão sobre práticas obstrucionistas, o trabalho de Eric Schickler (2001) é um ótimo começo.
} 
Entretanto, o estudo dos dados desagregados por coalizões, presentes no Anexo $\mathrm{E}^{41}$, revela momentos em que o governo quase se igualou à oposição em número de pedidos de verificação deferidos, quando não mesmo a ultrapassou nessa tarefa, normalmente dominada pelos partidos alheios à bancada que dá suporte ao chefe do Executivo no Congresso. É o que ocorre em Dutra III, Vargas I e II, Café Filho II, Quadros e Goulart I, V e VI, coalizões marcadas pela mudança na tônica mais geral, uma vez que a situação não se mostra, então, alheia ao referido recurso regimental - muito pelo contrário.

De fato, as observações sugerem que as checagens de deliberação atingiam lógicas distintas, dependendo do governo em vigor. A dificuldade em compreender os fatores determinantes das diferenças observadas aumenta em virtude das próprias peculiaridades inerentes a cada administração. Se do acordo interpartidário até a morte de Vargas houve relativa calmaria, a partir daí a tranqüilidade só seria recuperada no mandato de Kubitschek (1956-1959), que emergiria como o governo mais estável do período (BENEVIDES, 1979; CARVALHO, 1977). Afinal, trata-se da única presidência no pré-64 sufragada diretamente pelo povo que foi concluída na íntegra, sem convulsões políticas. Janio Quadros, seu sucessor, renunciaria em questão de oito meses. Na seqüência, João Goulart e a radicalização ideológica que se levanta sucumbem ao interregno autoritário de 1964.

Entretanto, o exame da dinâmica interpartidária em plenário é uma alternativa viável para se estudar, através de um referencial que transpassa várias coalizões governamentais, as possíveis razões que justificariam as lógicas distintas apresentadas pelas verificações de votação em diferentes composições parlamentares. Como o quadro partidário sofreu mudanças significativas somente após as eleições de 1962 para a Câmara Federal, quando os petebistas compõem a segunda maior bancada na Casa, desbancando a posição ocupada pela UDN desde 1945, é presumível que as legendas lancem luz aos saldos observados acima.

\footnotetext{
${ }^{41}$ Vide p. 139.
} 
Com efeito, a avaliação das autorias das checagens de deliberações por siglas evidencia que apenas no decorrer de duas administrações uma única legenda concentrou esmagadoramente a tomada dessa ação para si. Nada menos do que 48 das 62 verificações de votação concedidas nos menos de três meses de Nereu Ramos à frente da presidência do Brasil resultam de pedidos de reconsideração do resultado dirigidos por udenistas ao presidente da Câmara dos Deputados, prevalência de magnitude semelhante aos dados referentes aos anos JK, onde esse número é da ordem de 477 em 765, segundo as informações disponíveis no Anexo $\mathrm{F}^{42}$.

Uma hipótese que poderia explicar a coincidência de ambos estes achados se funda na idéia de que o padrão das verificações de votação possa variar de acordo com o órgão proponente das matérias objeto de decisão na Câmara. Válida, esta suspeição esclareceria tanto a ação do governo, que poderia pedir a checagem do resultado sempre que visse a sua agenda política desaprovada pelo plenário, como a conduta das siglas individualmente, conforme fosse a sua aproximação com o Executivo.

O gráfico 2 visa averiguar tal conjectura, confrontando as autorias das checagens de deliberação concedidas com as iniciativas das questões em apreciação:

${ }^{42}$ Cf. p. 140. 


\section{Gráfico 2.2 - Autoria dos pedidos de verificação concedidos, por grupo parlamentar, segundo a origem das matérias em votação $(1946-1964){ }^{43}$}

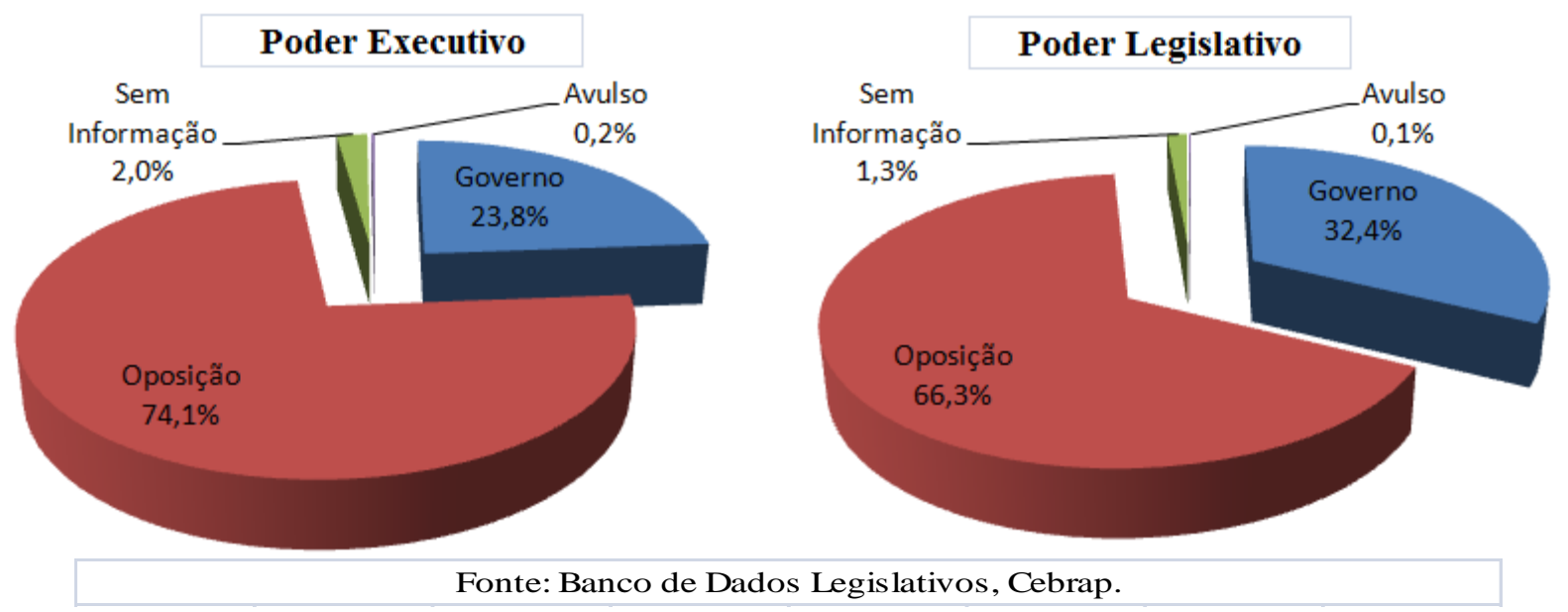

Como os desenhos atestam, não há variação no padrão da autoria dos pedidos de checagem de deliberação conferidos na democracia populista quando se diferenciam os dados por órgãos proponentes. Sejam questões apresentadas pelo Poder Executivo, sejam proposições oferecidas pelo Poder Legislativo, a oposição lidera em número a iniciativa de contestação do resultado da votação primária, anunciada pela Mesa, muito embora a coalizão formal de apoio ao governo também se manifeste com certa freqüência contra o saldo proclamado de acordo com a interpretação do diretor dos trabalhos na Câmara.

Seja como for, seria inapropriado restringir a investigação do processo decisório aos motivos que justificariam o predomínio da oposição nos pedidos de verificação concedidos durante a democracia populista. As leituras dos anexos E e G, somadas ao panorama pintado no gráfico 2, informam a mobilização do mesmo recurso regimental pelos partidos da base governista, nada desprezível, sobretudo quando consideramos os anos Vargas (1951-1954), com uma dinâmica inversa ao observado no quadro geral, com a situação pleiteando mais checagens do resultado de votações simbólicas do que as siglas que se opunham a ela. Nestes termos, maioria e minoria poderiam se valer do emprego tático desse instrumento regimental,

\footnotetext{
${ }^{43}$ A ilustração trata apenas dos poderes Executivo e Legislativo porque eles concentram a esmagadora maioria das matérias com checagem de votação deferida na Câmara dos Deputados. No Anexo G, porém, é possível conferir as informações desagregadas por coalizões e, inclusive, os dados relativos ao Poder Judiciário (vide p. 141).
} 
ainda que para propósitos totalmente assimétricos. Mais do que isto: parece haver uma manipulação estratégica do procedimento deliberativo em prol dos resultados políticos substantivos visados. Da mesma forma que soa bastante pertinente a probabilidade dos partidos alheios à base formal de governo ensejarem manobras de ação coordenadas pelo uso tático dos mecanismos regimentais, propondo revisões de votação para dificultar os trabalhos em plenário e, mesmo, emperrar a pauta do Congresso, é igualmente plausível que a situação se aproveitasse das verificações de quorum para medir sua força efetiva e coagir os seus a se manifestar em favor dos interesses do governo, quando não mesmo acelerar contato com membros da oposição, caso houvesse como cativá-los, em composições ad hoc. Se realmente existiam opções de voto a serem barganhadas pelos aliados do presidente mediante negociação com facções intrapartidárias adversárias, conforme a necessidade, tal qual a literatura tanto apregoa, não haveria melhor oportunidade para se conhecer as posições de todos os parlamentares, visualizar os desertores e sinalizar aos mercenários de plantão o início dos combates ${ }^{44}$.

\subsubsection{Uso estratégico do pedido de verificação}

Fundada no potencial informacional das verificações dos votos, capazes de permitir o controle do comportamento parlamentar sob a democracia populista, a afirmação relativa ao caráter ardiloso que motivaria as petições dirigidas à Mesa para averiguar o saldo de várias votações realizadas no parlamento - argumento central do presente trabalho - exige respaldo empírico cuidadoso, perpassando várias etapas. A primeira e mais elementar delas diz respeito

\footnotetext{
${ }^{44}$ No vocabulário militar, desertor é aquele que abandona o campo de batalha, fugindo ao confronto bélico. Embora a disciplina partidária não fosse uma exigência imposta pelas legendas do período seus filiados, a conduta independente dos parlamentares ligados à base parlamentar de apoio ao presidente na Câmara pode muito bem ser considerada digna de deserção. Na mesma linha, mercenário, termo usado para se designar o combatente profissional, que luta por dinheiro, soa bastante próprio para se aludir àqueles oposicionistas de fachada, que se rendem aos assédios do governo visando alguma compensação futura.
} 
à apuração da origem das votações nominais. É preciso saber se esse mecanismo decisório decorria predominantemente de solicitações de checagem do resultado da votação primária ou era produto mais freqüente de requerimentos para decisões nominais diretas. Apenas no primeiro caso a minha hipótese sobreviveria, com a indicação do uso tático que se fazia das verificações das deliberações naquele período.

O gráfico 2.3 disponibiliza justamente essa informação. Considere:

\section{Gráfico 2.3 - Origens das votações nominais (1946-1964)}

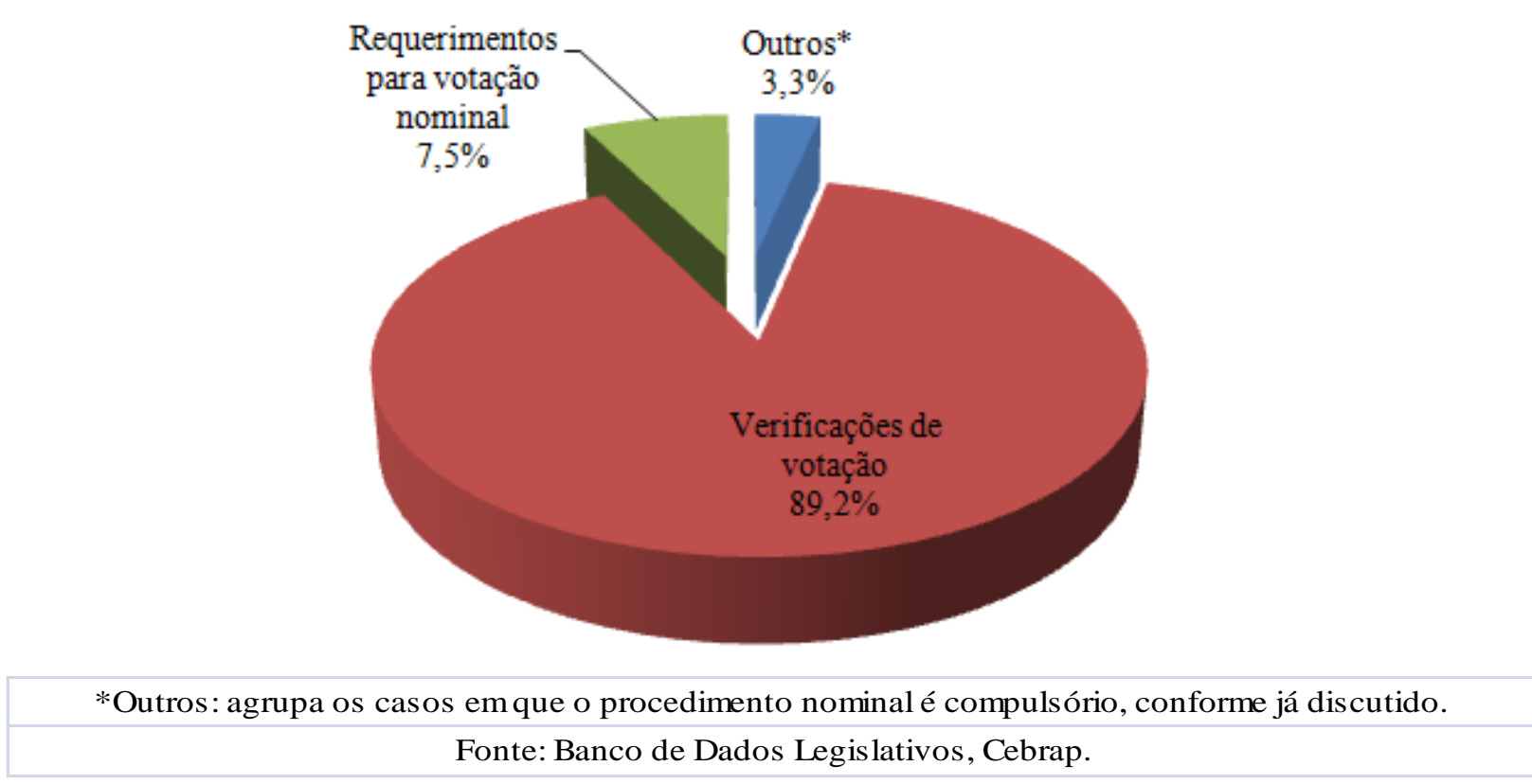

O quadro que emerge na figura acima suporta muito bem a suposição básica em jogo. Por quase $90 \%$ das vezes, o método nominal advém das checagens de votação deferidas na Câmara dos Deputados ao longo de todo o pré-64. Em todas as coalizões, sem exceção, as verificações de deliberações contestadas configuraram a razão, por excelência, daquele procedimento decisório (vide Anexo $\mathrm{H}^{45}$ ).

Minha conjectura passaria a ter mais consistência, entretanto, se emergisse um padrão de verificações de quorum inválidas - isto é, aquelas sem número legal e, portanto, incapazes de decidir a votação em andamento, exatamente para que o jogo político pudesse se

\footnotetext{
${ }^{45}$ Cf. p. 142.
} 
desenrolar nesse breve gap temporal entre um mecanismo decisório e outro. O objetivo do gráfico 2.4 é colocar à prova essa segunda condição, mas não menos importante, do exercício explicativo desenvolvido até aqui.

\section{Gráfico 2.4 - Saldo das verificações de quorum (1946-1964)*}

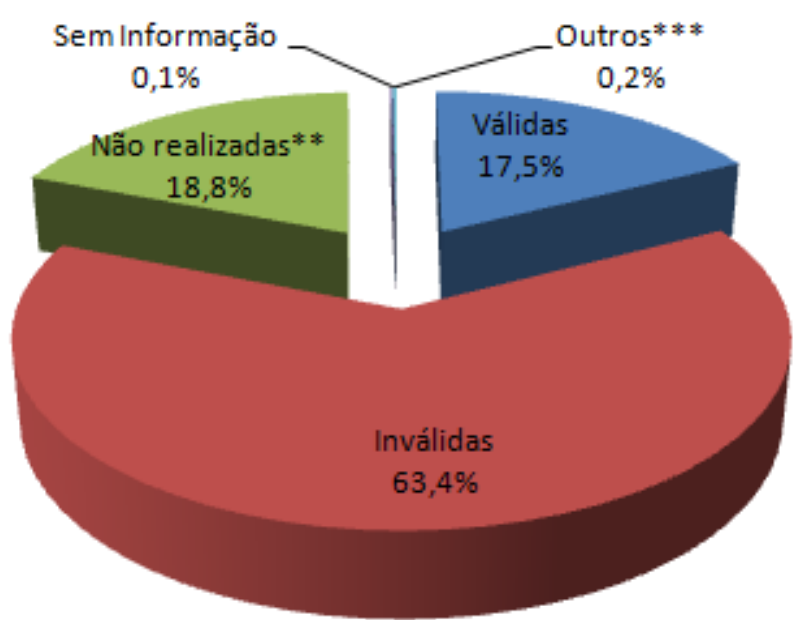

*Não realizadas: diz respeito às situações nas quais a checagem de número legal foi dispensada em função da opção do presidente pela chamada nominal direta. **Outros: corresponde aos casos em que o pedido de verificação de votação foi retirado pelo próprio requerente.

Fonte: Banco de Dados Legislativos, Cebrap.

Definitivamente, a checagem de quorum não era decisiva. Pouco mais de $15 \%$ delas hesitava em termos de solução efetiva das matérias em análise pelo plenário, atingindo número legal. A norma era a ausência de manifestações suficientes para sufragar uma escolha final, cuja freqüência beirava os dois terços das observações no pré-64 $(63,4 \%)$, com algumas oscilações no estudo desagregado por coalizões (Anexo I ${ }^{46}$ ).

Nestes termos, deparar com uma postura predominantemente discricionária do presidente da Câmara dos Deputados na condução do processo decisório completaria, de forma bastante atraente, a correspondência empírica alcançada pelas proposições anteriores. Afinal, era ele o ator que gozava de ampla arbitrariedade para interpretar o regimento a seu bel-prazer e alterar o rumo das decisões em andamento na Casa, independente da vontade do

\footnotetext{
${ }^{46}$ Cf. p. 143.
} 
plenário, sempre que não se atingisse quorum durante as verificações de votação. Como vimos na seção precedente, o próprio texto norteador dos trabalhos na Casa facultava ao diretor das sessões legislativas essa liberdade de ação ${ }^{47}$.

No gráfico 2.5, a discricionariedade do coordenador do processo decisório integra aquelas ocasiões em que o mesmo adiou uma verificação de votação quando a checagem de quorum revelou a inexistência de número legal como também todas as vezes nas quais sua escolha foi no sentido inverso - isto é, pelo prosseguimento da deliberação via chamada nominal. Em contrapartida, se considerou isento o procedimento do grande fiscal dos trabalhos na Câmara Federal nas demais situações, que abrangem desde a conclusão de votações na verificação de quorum, decididas por existência de número, até os casos de retirada do pedido de renovação da deliberação pelo próprio requerente.

As informações disponíveis realmente revelam que essa faculdade não foi ignorada. Observe:

\section{Gráfico 2.5 - Influência da conduta do presidente da Câmara no processo decisório (1946-1964)*}

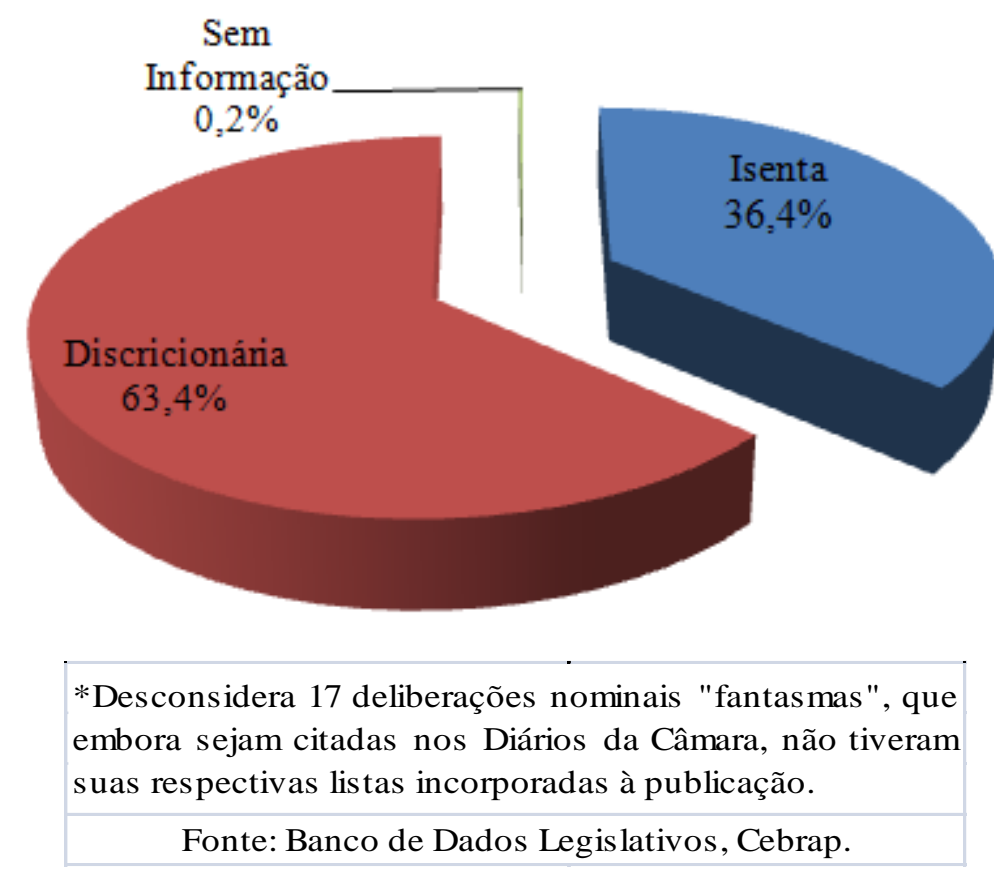

\footnotetext{
${ }^{47}$ Para recuperar a discussão, revise a figura 1.1, à p. 65.
} 
Como era esperado, há sinais do predomínio da suposta arbitrariedade do presidente no exercício de sua função, estimada decisiva em mais de $60 \%$ das observações sintetizadas no gráfico 2.5. Somente em algumas coalizões essa conduta se atenuaria, a ver pelos números retratados no Anexo $\mathrm{J}^{48}$. Infelizmente, porém, não reúno a soma dos pedidos de verificação indeferidos no mesmo período. Dessa forma, qualquer ponderação sobre o peso dessa aparente discricionariedade fica limitada pela impossibilidade de se avaliar até que ponto o presidente não passaria de um mero executor do regimento caso a norma fosse a sua alta propensão em conceder solicitações do gênero quando consultado pelos parlamentares neste sentido.

Ainda assim, é difícil acreditar que o grande "fiscal da ordem dos trabalhos" na Câmara agia como mero juiz do processo deliberativo, portando-se de forma totalmente neutra durante as decisões. Se este cargo não se revelasse tão proeminente do ponto de vista político, não haveria motivo para a maioria ter se empenhado em dominar a função ao longo de praticamente toda a democracia populista. Pela observação da distribuição das preferências na Casa, inclusive, há fortes indícios de que o governo ansiasse controlar as deliberações, via presidente, para reunir as forças necessárias à aprovação da sua agenda política, assegurando a vitória em plenário entre o pedido de verificação e a votação nominal.

\subsubsection{O padrão espacial da formação de preferências na democracia populista}

A interpretação usual sobre a dinâmica parlamentar vigente à República de 46 subentende a incongruência da ação dos legisladores em plenário a partir da inexistência do estatuto da disciplina partidária no período. Demasiado frouxas, as relações entre as legendas

e os seus respectivos membros na Câmara Federal permitiriam o domínio da ação

${ }^{48}$ Cf. p. 144. 
independente dos deputados, de modo que as cisões tão freqüentemente emergentes no seio das siglas refletissem no posicionamento dos representantes durante as votações, confuso do ponto de vista ideológico. Alas governistas e oposicionistas tenderiam a se manifestar, não raro, de forma semelhante, partilhando de visões comuns em termos de opção política.

Realmente, o estudo dos resultados obtidos a partir do método estatístico w-nominate, elaborado por Poole e Rosenthal (1985) para inferir as localizações espaciais dos parlamentares em uma ou mais dimensões através da sondagem estatística de seus respectivos posicionamentos sobre as políticas deliberadas nominalmente ${ }^{49}$, sinaliza a dificuldade de se disciplinar alguns deputados, com evidente postura independente frente à linha ideológica das legendas que representavam, nos moldes desenhados pela literatura. Ao estimar as posições multidimensionais dos representantes então empossados a partir de dois legisladores indicados como parâmetro ${ }^{50}$, o software denuncia a existência de várias composições aparentemente antagônicas, entre governo e oposição, ao invés de uma clara divisão entre os membros da coalizão e aqueles que dela não tomavam parte, ao menos, em termos formais.

A figura 2.1 apresenta as estimativas do wnominate para a democracia populista tomando por base as votações nominais em que pelo menos $10 \%$ dos parlamentares foram contrários ao resultado final - ponte de corte tradicionalmente empregado pela literatura para filtrar aquelas deliberações com real significância do ponto de vista do conflito partidário ${ }^{51}$.

\footnotetext{
${ }^{49} \mathrm{O}$ pressuposto básico do programa, portanto, é de que "as preferências individuais e as políticas podem ser representadas como pontos em um espaço. Os atores dão primazia às políticas mais próximas em detrimento daquelas que estão mais distante de seus pontos ideais" (LEONI, 2002, p. 361). É isto que inscreve o w-nominate na teoria espacial do voto parlamentar.

${ }^{50}$ Escolha do pesquisador, os legisladores-parâmetro devem ser escolhidos observando dois critérios. O primeiro é terem posicionamento político conhecido de antemão e fora de dúvida. O segundo exclui a possibilidade da opção ser por parlamentares que participaram pouco das votações, já que a alocação dos demais dependerá justamente da comparação com as manifestações dos dois eleitos como parâmetros de comportamento (cf. POOLE, 2005). As referências para os quatro governos do período que apresentaram número de nominais suficientes para o software conseguir calcular as estimativas dos parlamentares sob o ponto de corte de $10 \%$ de conflito mínimo - a saber, Dutra, Vargas, Café Filho e JK - foram Gustavo Capanema e Janduhy Carneiro, pessedistas históricos.

${ }^{51}$ Como bem recupera Nicolau (1999), os especialistas são consensuais sobre a necessidade de se incluir somente as deliberações que dividam minimamente o plenário em investigações com esta preocupação teórica sobre o conflito partidário. Em sistemas multipartidários como o brasileiro, "a opção é estabelecer um patamar de votos recebidos pelo lado minoritário ou majoritário”. O único problema dessa definição é encontrar um percentual
} 
Governos com observações insuficientes para os cálculos estatísticos realizados pelo software foram desconsiderados ${ }^{52}$.

\section{Figura 2.1 - Pontos ideais dos deputados por governos*}
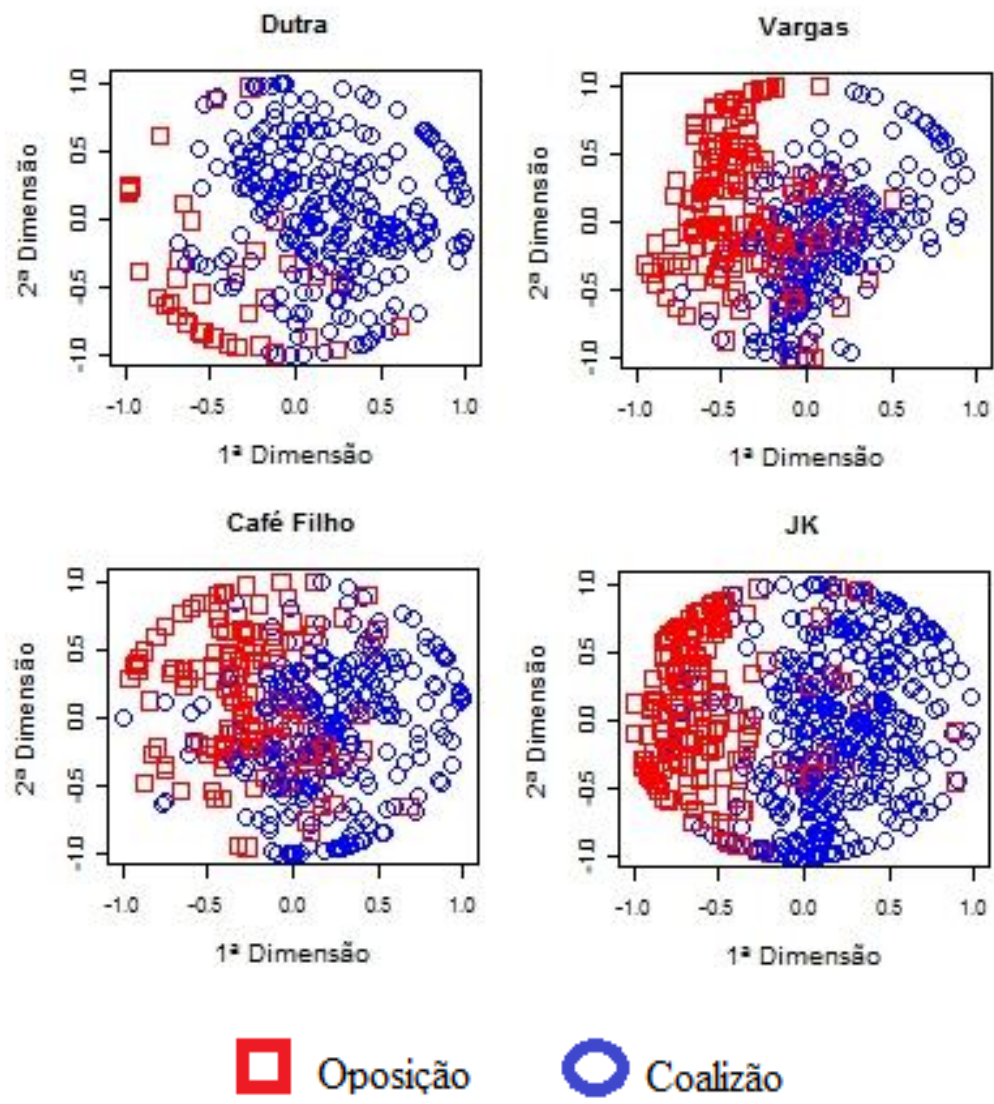

* Considera somente votações com, no mínimo, $10 \%$ de conflito partidário. Deputados migrantes foram duplicados.

Fonte: Banco de Dados Legislativos, Cebrap.

Nos gráficos acima, os quadradinhos vermelhos representam os membros da oposição enquanto os círculos azuis identificam os governistas. Detendo-nos apenas à leitura do eixo “x”, referência para o acompanhamento da primeira dimensão do modelo, notamos a

inteligente para o recorte, já que "um patamar muito alto tende a sobredimensionar a média da disciplina dos partidos e um muito baixo tende a subdimensioná-la" NICOLAU (1999, p. 4).

Eliminando as votações nas quais pelo menos $90 \%$ dos deputados se manifestaram de modo idêntico, Limongi e Figueiredo (1995, p. 518) escolheram um ponto de corte bastante moderado. Tendo se disseminado, foi o seguido no estudo presente.

${ }_{52} \mathrm{Na}$ realidade, o wnominate não estabelece, por definição, um número mínimo de casos. Isso varia em função da assiduidade dos parlamentares nas votações e do ponto de corte definido pelo analista. As informações relativas às perdas ocorridas em cada gráfico consumado pelo software serão apresentadas ao longo da discussão que segue. 
ocorrência de duas tendências distintas seguidas por ambas as frentes parlamentares. Em Vargas e JK, emerge uma divisão mais clara entre essas alas, diferentemente do ilustrado em Dutra e Café Filho. Ainda assim, nessas cisões mais demarcadas há deputados que invadem o espaço do grupo teoricamente antagônico, ao menos em termos de localização formal em relação à situação no poder político.

Descartadas 58 nominais unânimes, as 114 votações restantes ocorridas sob o governo Dutra mostram que o Acordo Interpartidário de 1948, por si só, não bastou para unificar um padrão de ação governista. Tanto é assim que não se supõe qualquer diferença significativa entre a localização espacial entre os membros da coalizão e os oposicionistas. Com menor intensidade, avaliação semelhante cabe às observações verificadas na administração Café Filho, que somam 123 nominais, descontadas 40 votações unânimes. A divisão entre as posições dos pontos ideais referentes a governistas e deputados de oposição é bastante diminuta, prevalecendo a sensação de que a disposição formal de cada legislador frente ao Poder Executivo pouco influía na construção das preferências expressas.

No governo Vargas, porém, a separação entre os grupos parlamentares é mais nítida. Estimativas construídas a partir da análise de 250 nominais, dada a exclusão de 58 decisões unânimes, afastam muito mais a coalizão e os opositores, embora persistam muitos pontos ideais distribuídos na direção diversa da esperada em se tratando de estratégia política - mais exatamente, em se compor ou não com o Executivo no parlamento. Somente no mandato de JK a localização espacial entre governistas e membros da oposição de fato ganha mais definição. O exame das estimativas derivadas de 437 nominais, eliminadas 205 votações unânimes, aponta a menor incidência de supostos outilers relativos aos sentidos que deveriam, em tese, tomar.

É bem verdade que, passando à consideração do eixo “y”, norteador de possíveis dimensões secundárias, ficam patentes distinções mais salientes também em Café Filho, além 
de Vargas - já marcado por um plenário bem dividido na primeira dimensão. Para Poole e Rosenthal (1985), é a análise dos escores APRE e Correct Classification, somados à consideração dos Eigenvalues, que nos ajudam a decifrar a dimensionalidade de um modelo espacial. O primeiro diz respeito à redução proporcional do erro agregado - uma estimativa da superioridade do modelo estatístico frente a estimativas sem orientação matemática - ou seja, "chutes ingênuos". Quanto mais perto de 1 (um), melhor se crê a estimativa do modelo. Todavia, resultados em torno de 0,5 (meio) normalmente são considerados bons (Poole, 2005).

Como o próprio nome sugere, o Correct Classification (CC), por sua vez, destaca a capacidade de acerto do modelo espacial a cada nova dimensão testada, tomado por adequado a partir de $85 \%$. Finalmente, os Eingenvalues, visualizados em gráficos chamados scree plots, nos permitem acompanhar a tendência da distribuição das preferências pela formação de “cotovelos", ou seja, quedas acentuadas na explicação adicional que nos autorizam a supor as diferentes dimensionalidades de um mesmo modelo espacial.

No caso da administração Dutra, o CC estima 80,9\% de precisão para um modelo unidimensional, que se ressente de um APRE modesto (0.298). Na hipótese de uma segunda dimensão, porém, estes mesmos escores sobem muito pouco, chegando a 82,9\% e 0.372 , nesta ordem. Dados sobre a presidência posterior nos trazem luz sobre tais conjecturas, já que, desta vez, as estatísticas revelam escores bem piores. Em Vargas, a suposição de uma única dimensão não suplantaria um CC de $76.2 \%$, com APRE de 0.201. Sob a presunção de bidimensionalidade, os números saltam para $79.27 \%$ e 0.305 , respectivamente - ganhos bastante significativos. Estes números são praticamente idênticos aos observados nos modelos espaciais estimados para o mandato de Café Filho. Se o teste unidimensional oferece CC igual a 76,0\% e APRE de 0.227, a hipótese bidimensional rende CC de 79,4\% e APRE de 0.335 e também parece a visão mais adequada do plenário no período. Com efeito, nem mesmo os 
anos JK emparelhariam com o primeiro governo da República de 46, de Dutra, em termos de aparente unidimensionalidade. Na experiência de Juscelino, essa hipótese alcançaria resultados melhores se comparada com a dos dois governos precedentes, com CC na casa de 79,1\% e APRE de 0.31. Ainda assim, os incrementos estatísticos a partir da presunção da bidimensionalidade se fariam relevantes $-81,2 \%$ e 0.38 , para ser exata.

Os screes plots complementam todas essas avaliações. Veja:

Figura 2.2 - Scree plot dos governos
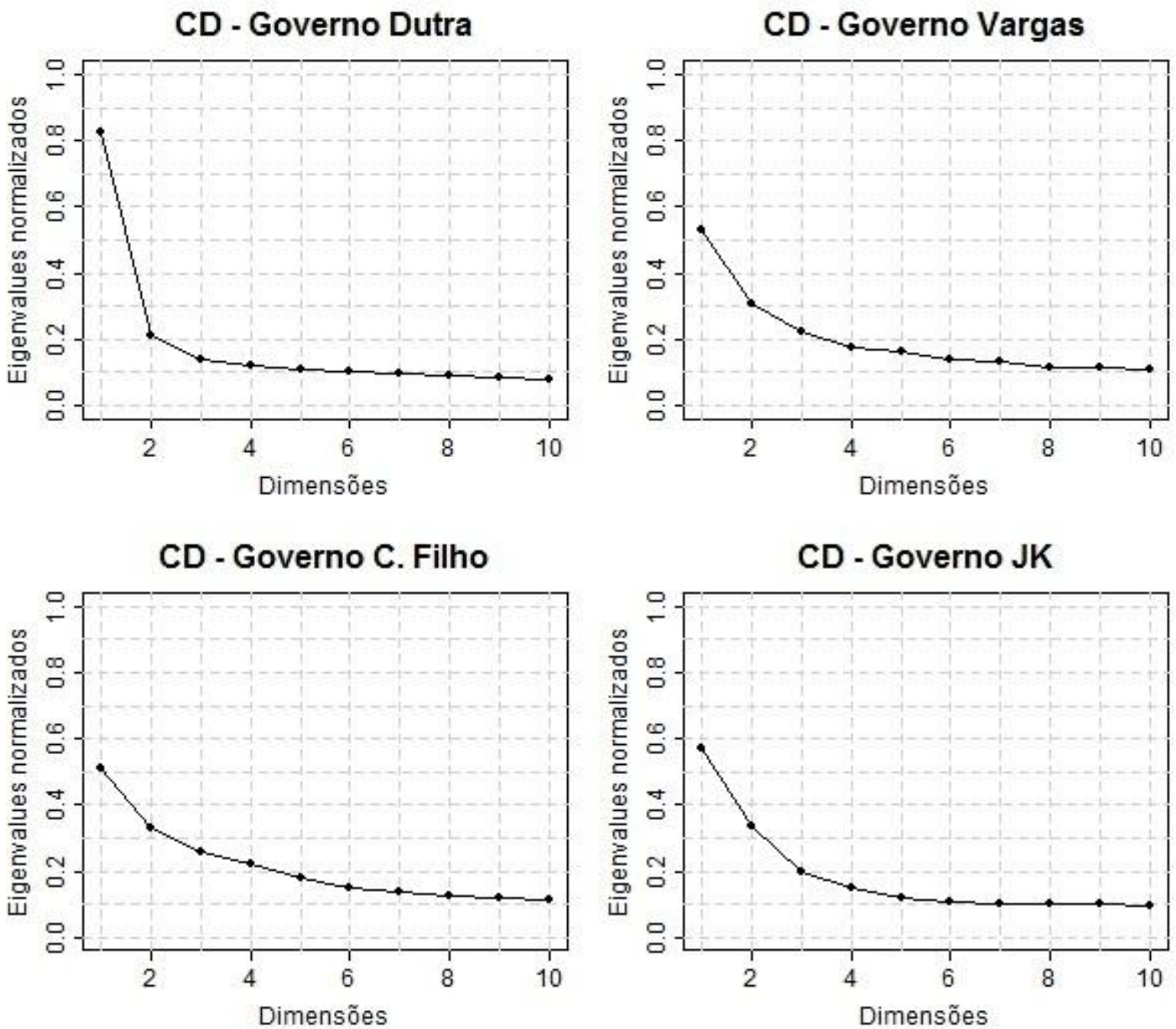

Fonte: Banco de Dados Legislativos, Cebrap. 
À exceção da administração Eurico Gaspar Dutra, onde o "cotovelo" do scree plot encerra nitidamente uma única queda acentuada, em todas as demais os incrementos de cada novo cotovelo se revelam razoavelmente próximos, fortalecendo a tese da bidimensionalidade nestes casos.

O mais importante a destacar, entretanto, é que panorama não diverge dirigindo a análise por coalizões, conforme registrado no Anexo $\mathrm{K}^{53}$. Embora essa opção ajude a identificar melhor o momento em que a segunda dimensão passa a se sobressair e alterar o eixo espacial da distribuição de preferências, nenhum dos arranjos políticos aplicáveis ao wnominate ficou imune dos pontos ideais cujo comportamento o governo poderia tanto temer. Realmente, vários membros da coalizão se posicionavam de forma totalmente dissonante da conduta da maioria parlamentar, que nunca se mostra deveras unida. Por outro lado, um número razoável de deputados eleitos pela oposição se imiscuía entre o terreno mais povoado pelos governistas. Procedem, assim, os registros históricos que tanto salientam a prevalência das facções intrapartidárias ao longo de todo o pré-64. Resta saber apenas se tais cisões tendiam ou não a alterar a política da época.

Mais precisamente, a dúvida imediata que se levanta comporta a capacidade da base parlamentar de apoio ao Executivo na Câmara enquanto financiadora exclusiva dos resultados políticos substantivos nas deliberações realizadas em plenário. Será que o assédio à oposição, tão apregoado pela literatura, se fazia capital para a situação assegurar a governabilidade? O comportamento faccional se faria decisivo para os resultados políticos intencionados pelo presidente da República ou a coalizão se bastava neste fim? Haveria correlação alta entre o conteúdo da policy e a conduta das bancadas nas votações que tinham lugar no Legislativo Federal? Eis o tom do próximo capítulo, que pretende medir o alcance concreto das cisões partidárias frente ao decision-making em 46-64.

\footnotetext{
${ }^{53}$ Consulte p. 145.
} 


\section{CAPÍtulo 3 - Facciosismo e capacidade decisória na República de 46}

A visão dominante retrata a democracia populista como um constante desafio administrativo. Mancomunações políticas sucessivas constituiriam uma agenda paralela do Executivo, que se veria impedido de relaxar na busca pela manutenção de maiorias capazes de lhe assegurar o apoio almejado no parlamento. Até a radicalização ideológica que culminaria em paralisia decisória e faria a República de 46 sucumbir ao golpe militar de 1964, a barganha entre presidente e Congresso seria a tônica do período, grafado na história do país como uma experiência distinta exatamente pela predominante sensação de crise iminente.

Mesmo a administração de JK, considerada a mais estável da época, teria evitado depender de auxílio parlamentar para fazer valer a legislação de seu interesse. Segundo Celso Lafer (2002), Juscelino preferira optar por contornar tanto a Câmara quanto o Senado, autorizando parte das medidas cobertas pelo seu Plano de Metas ${ }^{54}$ através da imposição de decretos. Antecipando possíveis estrangulamentos orçamentários que poderiam ser ratificados em ambas as casas, comprometendo seu programa de trabalho, o presidente lançaria mão das contas de fundos especiais, "previstas na Constituição de 1946 para facilitar a cooperação financeira entre a União, os estados os municípios e as áreas econômicas regionais", seja criando novas concessões do gênero, seja utilizando as já existentes, vinculando-as diretamente à consecução de determinadas metas (LAFER, 2002, p. 90). Desta forma, se garantiram a maior parte dos recursos necessários à realização do seu programa desenvolvimentista, apesar de $45 \%$ da receita complementar ficar na dependência de alocações orçamentárias anuais, revestindo-se

\footnotetext{
${ }^{54}$ Trata-se de um programa de ação administrativa engenhado por Kubitschek com vistas ao desenvolvimento socioeconômico, com dois motes principais. Um dos objetivos em jogo era sintonizar a burocracia federal e o eleitorado, cujo crescimento vertiginoso num curto espaço de tempo reverberava nos órgãos públicos, incapazes de atender as novas demandas dessa base política do sistema que lhes legitimava - ampliada, carente e insatisfeita com as condições de vida que levava. Outra ambição era executar efetivamente a substituição de importações, apontada como a maior limitação ao avanço das finanças internas.
} 
“de peso eminentemente político, pois representava o campo de barganha possível, acionando o mecanismo de feedback do sistema, sua válvula de segurança e suas fontes de apoio [...] De fato, a margem de investimentos a curto prazo podia ser manipulada para atender aos interesses da coalizão de forças políticas em torno de Kubistchek" (Ibid., p. 94, grifo meu).

O curioso é que vários desses fundos especiais foram adaptados aos objetivos de JK pela manifestação do Congresso segundo informações do próprio autor. O Fundo Rodoviário Nacional, por exemplo, datado de 1945, foi revisado pela Lei ${ }^{\circ}$ 2.975, de 27/11/1956, só assim tornando-se aplicável nos moldes desejados pelo governo. O mesmo vale para o Fundo Nacional de Pavimentação - de 1953, mas adaptado para ser destinado à realização das metas pela Lei n 2.698, de 27/12/1955 - e para uma série de outras rendas congêneres discutidas por Lafer, que superam os empreendimentos de Juscelino alheios ao Poder Legislativo tão enfatizados pelo analista (LAFER, 2002, cap. 2).

Examinando o tema, Maria Victória Benevides se mostrou um pouco mais cuidadosa, embora também imprecisa, como veremos mais adiante. A autora afirmou que “todas as questões referentes aos fundos para a implementação do Programa de Metas foram decididas sempre por meio de votações simbólicas (e não nominais), o que indica[ria] o consenso quanto às lideranças partidárias em torno do assunto (BENEVIDES, 1979, p.78-79).

Na sua versão,

"Independentemente das questões vinculadas diretamente ao orçamento, o Legislativo aprovou importantes projetos de lei, oriundos de mensagens do Executivo ou de sua própria iniciativa. Não resta a menor dúvida de que esse apoio não foi tão expressivo quanto em relação ao orçamento, pois predominava o nível sistêmico (nas relações Executivo-Legislativo) e cabia ao Congresso acomodar os diversos interesses das facções aí representadas. Foi, de qualquer modo, bastante significativo, em comparação com os outros governos e principalmente levando-se em conta a morosidade já considerada 'normal' nos trâmites dos projetos pelas comissões, 
plenário, etc., pela própria inércia burocrática e pelas tentativas obstrucionistas da oposição" (Ibid., p. 79, grifo meu).

Concordando com Benevides a respeito do reconhecimento do papel do Legislativo na aprovação de uma fatia razoável dos recursos essenciais ao processo desenvolvimentista de Juscelino, provenientes das decisões acalentadas no Congresso sobre investimentos de curto prazo a serem fechados no orçamento anual, Wanderley Guilherme dos Santos (2003) lidera a primeira análise sistemática dessas relevantes deliberações. Sua investigação contesta a afirmação da autora, revelando que razoável fração das votações referentes à grande obra de JK se construiu pela via nominal. Pelo exame desse recorte, Wanderley concluiu que a base do sucesso da ambiciosa agenda administrativa de Kubistchek

\footnotetext{
“- o apoio parlamentar para um plano governamental de longo prazo - não se restringiu à aliança exclusiva entre o PSD e o PTB, o que não teria sido suficiente, mas cristalizou-se em uma coalizão parlamentar majoritária incluindo também uma facção da UDN, sempre que aspectos fundamentais do Plano de Metas estivessem em tela de juízo" (SANTOS, 2003, p. 277, grifos meus).
}

Daí sentenciar que, não fosse a cooperação dos udenistas, o sistema parlamentar de então "teria representado ameaça bem maior para o Executivo do que se imagina tenha sido" (Ibid., p. 281).

Todo esse pessimismo, repito, dirigido à administração tida como a mais estável do pré-64. Que esperar das demais então, com registros históricos muito mais desoladores, a ver pelas recorrentes crises políticas? A norma deveria ser a formação de coalizões ad hoc, para o temor do governo, que nunca contava com folga quando o assunto era apoio perene e confiável na Câmara dos Deputados.

Neste capítulo, o objetivo é pôr à prova as interpretações mais usuais sobre a governabilidade no pré-64. Através da crítica dos resultados das votações nominais ocorridas no período, discuto a formação de maiorias em plenário, contestando o peso normalmente 
imputado ao faccionalismo enquanto variável determinante dos saldos políticos delineados no Legislativo Federal. O acompanhamento sistemático da agregação de preferências a partir dos inputs do governo mostrará que os especialistas tendem a sobredimensionar a influência das cisões intrapartidárias sob a capacidade decisória gozada pela primeira experiência democrática brasileira. Em geral, a coalizão de apoio ao presidente no parlamento conseguia administrar, sozinha, o alcance das metas que realmente estimava. Nem mesmo a clássica temática regionalista, sintonizada com a tradição política da época, alteraria significativamente o padrão deliberativo, bastante distinto do apregoado pelos estudos disponíveis até o momento. O hipotético efeito separatista que tanto se atribui à propensão paroquial dos deputados então elevados ao poder não ultrapassaria o âmbito da oratória, mais empenhada em sinalizar o comprometimento dos representantes para com seus eleitores do que finalizada a impactar a dinâmica interpartidária.

\subsection{Vitórias e derrotas do governo na Câmara dos Deputados}

Seja em estudos de casos, seja em análises mais gerais, o panorama normalmente delineado pela literatura apresenta a governabilidade na República de 46 como uma preocupação contínua do Poder Executivo. A desconfiança inerente à conduta coesa e o real comprometimento dos partidos que compunham a base de apoio do presidente no Legislativo levaria o dirigente da República a barganhar, com freqüência, os preciosos votos das várias cisões existentes no seio da oposição, visando reunir a sustentação parlamentar almejada na construção da coalizão, sempre abalada pela independência dos deputados, em tese, alinhados ao programa administrativo em voga.

Parece bastante interessante iniciar o teste da procedência desse diagnóstico a partir da hipótese de Amorim Neto e Fabiano Santos (2001) sobre a diminuição do apoio gozado pelo 
Executivo na Câmara dos Deputados ao longo do seu mandato, nos termos discutidos no capítulo 1. Nesta leitura, os embates entre situação e oposição deveriam ser reforçados no plenário conforme o exercício governamental em voga caminhasse para o fim.

O gráfico 3.1 mira a comparação do número de verificações de votação deferidas ao longo dos governos, agrupando-as segundo a duração das presidências.

\section{Gráfico 3.1 - Distribuição das verificações de votação, por anos do mandato presidencial (1946-1964)*}

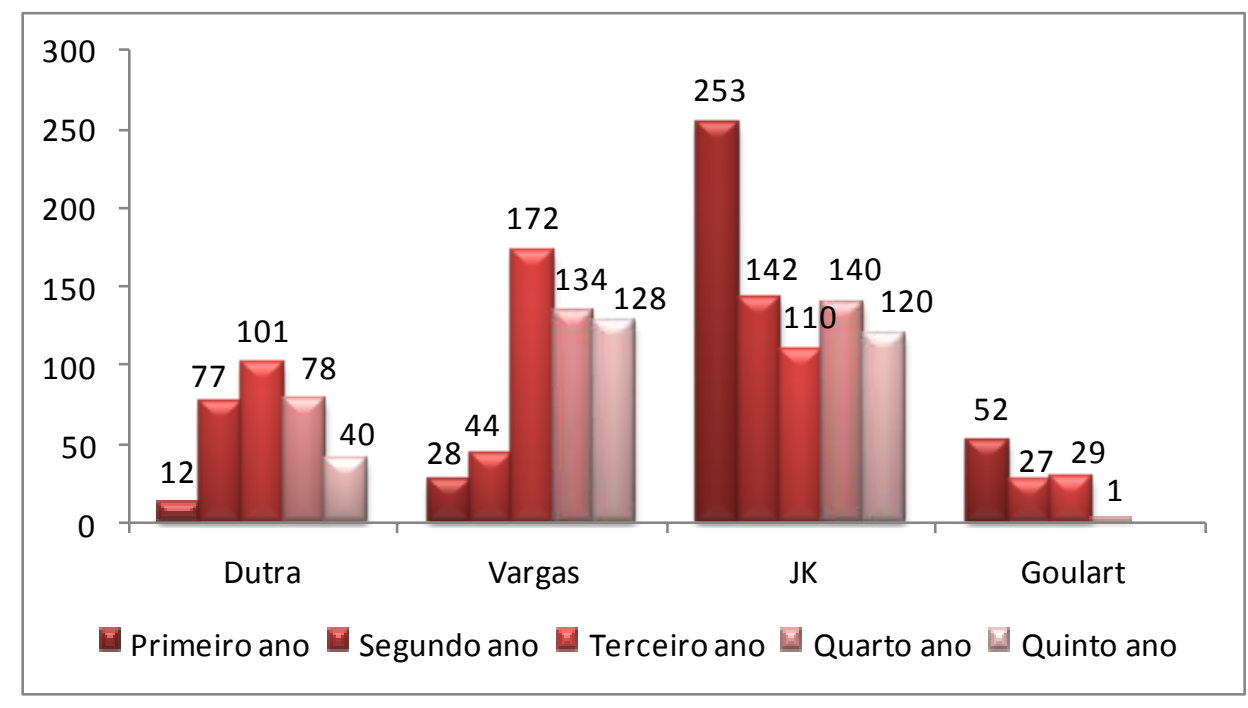

* Agrupa as checagens de deliberação ocorridas em função da duração de cada governo, por anos do mandato presidencial. Desconsidera somente as passagens de Ranieri Mazzili e Jânio Quadros pelo posto, que ocuparam por menos de um ano. Como Café Filho assumiu a liderança de Vargas após a morte de Vargas, foi incorporado na gestão do ex-ditador, para fins de análise.

Fonte: Banco de Dados Legislativos, Cebrap.

Pelos saldos observados, o conflito entre situação e parlamento apenas não parece ter seguido a lógica aventada pelos autores em JK, quando se observa alta concentração de checagens de número legal logo no primeiro ano do mandato presidencial. Nas administrações Dutra e Vargas, os confrontos em plenário aumentam exatamente ao longo das referidas gestões, com destaque para o terceiro ano de ambos os governos, com o maior número de 
observações $^{55}$. No caso de Goulart, o curioso é a baixa freqüência das verificações de votação, conhecida a histórica dificuldade do chefe do Executivo em compor maiorias na Câmara.

É tempo de averiguar quão impactante eram esses duelos para a capacidade decisória da democracia populista. A rigor, as checagens de quorum facultavam tanto à coalizão observar a própria coesão interna quanto à oposição tomar conhecimento da concreta divisão de forças estabelecida em plenário. Ambos os grupos conseguiam vislumbrar o poder numérico gozado no momento das sessões deliberativas e calcular a dimensão do faccionalismo, em termos de custo político, para cada uma das bancadas vítimas de cisões partidárias aparentemente irresolúveis ao time da votação.

Apanhar a margem de (in)dependência do governo frente às tão apregoadas composições ad hoc perpassa, entretanto, por algumas escolhas metodológicas. Afinal, os líderes partidários raramente orientavam a posição do partido que representavam, tendendo a subir à tribuna, para encaminhamento de votação, na qualidade de parlamentares com visão crítica da matéria a ser decidida. Somente com a publicação da Res. n 71 , de 1962, a indicação da preferência de cada sigla representada na Câmara entraria para a rotina regimental da Casa, como o capítulo 1 frisou.

Sob esse imperativo conjuntural, pensar em vitórias e derrotas do governo exige definir as situações nas quais a sua posição seja minimamente bem deduzida através dos dados disponíveis. A meu ver, dois conjuntos de proposições são capazes de cultivar a proxy mais adequada à preferência da situação nas deliberações levadas a cabo no plenário. $\mathrm{O}$ primeiro deles abarca as iniciativas legislativas do Executivo decididas no decurso do próprio mandato do presidente que a rubrica. Isto porque não seria razoável o dirigente do país

\footnotetext{
${ }^{55}$ Vale pontuar que Dutra foi conduzido ao cargo por decisão do Congresso constituinte, que também passa a Congresso ordinário logo após a publicação da Carta de 1946. Assim, as verificações de votação para o primeiro ano de seu mandato passam a ser contabilizadas a partir do mês de outubro, quando é oficialmente empossado. Daí segue, muito provavelmente, número de observações tão diminuto.
} 
despender energia apresentando projetos alheios ao seu interesse. Se o faz, deve ansiar pelo sucesso da sua proposta política.

De fato, a maior parte dos tópicos sublinhados pela literatura como prioritários dentre os assuntos em pauta à República de 46 abarca exatamente regulações oferecidas pelo Executivo Federal ${ }^{56}$. No Anexo L há uma síntese dessas temáticas admitidas como centrais pela bibliografia especializada, preponderando iniciativas de nítido apelo administrativo, em consonância com o mote classificatório agora em defesa ${ }^{57}$.

Perseguindo lógica semelhante, o segundo conjunto de medidas, por sua vez, compreende as matérias assinadas por membros da coalizão em voga quando as questões seguem à deliberação. Isso inclui não somente as proposições elaboradas por deputados governistas individualmente, como também aqueles projetos organizados pelas comissões permanentes presididas por representantes de legendas alinhadas ao chefe do Executivo na Câmara. A categoria compreende, ainda, propostas assinadas pela Mesa Diretora da Casa, sempre que seu diretor estivesse filiado à situação. Desta vez, assume-se que todo este conjunto de políticas é importante para o governo como um todo.

Feitas tais ponderações, o sucesso do Executivo na Câmara pode ser capturado pela consagração da posição majoritária do partido do presidente no resultado final da votação nominal de matérias iniciadas por este poder, à exceção das deliberações do gênero realizadas após a institucionalização da indicação de voto, em 1962. Com a mudança, nada melhor do que tomar por referência a manifestação do líder da sigla que elegeu o dirigente do país. Por extensão do raciocínio, o êxito do governo na Casa em questões assinadas por membros da sua base parlamentar passa a ser apreendido em função da vitória, em plenário, da preferência majoritariamente configurada no interior da coalizão.

\footnotetext{
${ }^{56} \mathrm{O}$ debate sobre o teor da policy e a variação nos resultados deliberativos não é novo. Remonta a Mayhew (1991). Para um balanço desta discussão, ver Ricci (2010).

${ }^{57}$ Cf. p. 150.
} 
Sintonizada com todos os critérios discutidos, a tabela 3.1visa confrontar as previsões da literatura com os resultados políticos substantivos atingidos em plenário:

Tabela 3.1 - Vitórias e derrotas do governo, por coalizão, em votações nominais (1946-1964)*

\begin{tabular}{|c|c|c|c|c|c|c|c|c|}
\hline \multirow{3}{*}{ Coalizão } & \multicolumn{7}{|c|}{ Vitórias e derrotas do governo } & \multirow{3}{*}{ Total } \\
\hline & \multicolumn{3}{|c|}{$\begin{array}{l}\text { Somente em iniciativas do } \\
\text { Executivo }\end{array}$} & \multicolumn{4}{|c|}{$\begin{array}{c}\text { Em iniciativas da sua base parlamentar } \\
\text { na Câmara }\end{array}$} & \\
\hline & Vitórias & Derrotas & Total & Vitórias & Derrotas & SI** & Total & \\
\hline Dutra II & 3 & - & 3 & 61 & 2 & 14 & 77 & 80 \\
\hline Dutra III & 13 & - & 13 & 19 & - & 1 & 20 & 33 \\
\hline Vargas I & 34 & 4 & 38 & 62 & 9 & 3 & 74 & 112 \\
\hline Vargas II & 26 & 4 & 30 & 91 & 7 & 1 & 99 & 129 \\
\hline Vargas III & - & - & - & 4 & - & - & 4 & 4 \\
\hline Café Filho II & - & - & - & - & - & 2 & 2 & 2 \\
\hline JK I & 39 & 3 & 42 & 140 & 7 & 7 & 154 & 196 \\
\hline JK II & 27 & - & 27 & 85 & 3 & 1 & 89 & 116 \\
\hline Quadros & - & - & - & - & 1 & - & 1 & 1 \\
\hline Goulart II & 1 & - & 1 & 1 & - & - & 1 & 2 \\
\hline Goulart IV & - & - & - & - & - & 2 & 2 & 2 \\
\hline Goulart V & 2 & - & 2 & 2 & - & - & 2 & 4 \\
\hline Goulart VI & 1 & 1 & 2 & 4 & - & 5 & 9 & 11 \\
\hline Total & $\begin{array}{c}146 \\
(92,4 \%)\end{array}$ & $\begin{array}{c}12 \\
(7,6 \%)\end{array}$ & 158 & $\begin{array}{c}\mathbf{4 6 9} \\
(87,8 \%)\end{array}$ & $\begin{array}{c}29 \\
(5,4 \%)\end{array}$ & $\begin{array}{c}36 \\
(6,7 \%)\end{array}$ & 534 & 692 \\
\hline
\end{tabular}

*Considera apenas votações válidas. Exclui duas deliberações incapazes de se calcular a posição do partido do presidente, porque tal legenda se dividiu - uma ocorrida em Vargas I e outra, em Quadros. A título de exposição, as coalizões que apresentam todas as caselas serão omitidas nas tabelas. **SI: Sem Informação - Diz respeito a projetos de autoria de senadores e comissões mistas, desconsiderados na classificação das iniciativas da base parlamentar do governo na Câmara Federal.

Fonte: Banco de Dados Legislativos, Cebrap.

Raras foram as ocasiões em que o governo viu os seus propósitos mitigados pelas preferências manifestas no parlamento. Nas decisões circunscritas às iniciativas do Executivo, o êxito deste poder ficou em torno de $90 \%$ para o período 46-64, com vários episódios de máxima eficiência, a ver pelas muitas coalizões que não amargaram sequer uma derrota em plenário na apreciação de matérias iniciadas por este poder. Com respeito às apreciações de questões interpostas pela sua base parlamentar de apoio na Câmara dos Deputados, o saldo positivo tem uma leve queda $(87,8 \%)$, mas ainda assim se revela muito satisfatório. 
Nesta conjuntura, se torna mais difícil dar por certa a visão convencional, que atribui a capacidade decisória das administrações então em voga ao contínuo cortejo do presidente a facções intrapartidárias que não compunham formalmente sua coalizão de forças no Legislativo. Dirimir essa aparente contradição é o propósito da tabela 3.2, que informa como se cultivaram os resultados demasiado positivos observados acima.

Tabela 3.2 - Tipos de vitória do governo, por coalizão, em votações nominais (1946-1964)*

\begin{tabular}{|c|c|c|c|c|c|c|c|}
\hline \multirow{3}{*}{ Coalizão } & \multicolumn{6}{|c|}{ Tipo de vitória } & \multirow{3}{*}{ Total } \\
\hline & \multicolumn{3}{|c|}{$\begin{array}{c}\text { Somente em iniciativas do } \\
\text { Executivo }\end{array}$} & \multicolumn{3}{|c|}{$\begin{array}{c}\text { Em iniciativas da sua base } \\
\text { parlamentar na Câmara }\end{array}$} & \\
\hline & $\begin{array}{c}\text { Apenas com } \\
\text { os membros } \\
\text { da coalizão }\end{array}$ & $\begin{array}{l}\text { Com a ajuda } \\
\text { da oposição }\end{array}$ & Total & $\begin{array}{c}\text { Apenas com } \\
\text { os membros } \\
\text { da coalizão }\end{array}$ & $\begin{array}{l}\text { Com a ajuda } \\
\text { da oposição }\end{array}$ & Total & \\
\hline Dutra II & 3 & - & 3 & 61 & - & 61 & 64 \\
\hline Dutra III & 13 & - & 13 & 19 & - & 19 & 32 \\
\hline Vargas I & 32 & 2 & 34 & 53 & 9 & 62 & 96 \\
\hline Vargas II & 15 & 11 & 26 & 37 & 54 & 91 & 117 \\
\hline Vargas III & - & - & - & 4 & - & 4 & 4 \\
\hline JK I & 35 & 4 & 39 & 119 & 21 & 140 & 179 \\
\hline JK II & 25 & 2 & 27 & 78 & 7 & 85 & 112 \\
\hline Goulart II & 1 & - & 1 & 1 & - & 1 & 2 \\
\hline Goulart V & 2 & & 2 & 2 & - & 2 & 4 \\
\hline Goulart VI & 1 & - & 1 & 2 & 2 & 4 & 5 \\
\hline Total & $\begin{array}{c}\mathbf{1 2 7} \\
(87,0 \%)\end{array}$ & $\begin{array}{c}19 \\
(13,0 \%)\end{array}$ & 146 & $\begin{array}{c}\mathbf{3 7 6} \\
(80,2 \%)\end{array}$ & $\begin{array}{c}93 \\
(19,8 \%)\end{array}$ & 469 & 615 \\
\hline
\end{tabular}

Os dados mostram que as contribuições da oposição eram residuais. Somente em Vargas II o auxílio externo teve importância efetiva para os objetivos do governo, chegando a determinar 65 dos 117 resultados favoráveis estimados pelo grupo no poder. As iniciativas da base parlamentar do ex-ditador na Câmara foram as que mais gozaram desse respaldo oposicionista, assegurando a vitória da posição majoritária da coalizão que o cercava em 54 $(59,3 \%)$ das 91 votações do gênero.

Se este quadro fosse resultado do uso estratégico da verificação de quorum pela situação visando o teste prévio das respectivas forças em plenário e, por extensão, o 
desenrolar da barganha política para a formação das maiorias essenciais à vitória, a prosperidade administrativa nele sinalizada deveria encerrar alta correlação com as checagens das deliberações deferidas entre 46 e 64 . Esse teste é o foco da próxima tabela, que trata das iniciativas do Poder Executivo separadamente, por questões expositivas. Considere:

Tabela 3.3 - Tipos de vitória do governo, por coalizão, segundo a escolha procedimental, em votações nominais de matérias iniciadas pelo Executivo (1946-1964)*

\begin{tabular}{|c|c|c|c|c|c|}
\hline \multirow{3}{*}{ Coalizão } & \multicolumn{4}{|c|}{ Tipo de vitória } & \multirow{3}{*}{ Total } \\
\hline & \multicolumn{2}{|c|}{$\begin{array}{l}\text { Apenas com os membros } \\
\text { da coalizão }\end{array}$} & \multicolumn{2}{|c|}{ Com a ajuda da oposição } & \\
\hline & $\begin{array}{c}\text { Verificação de } \\
\text { quorum prévia }\end{array}$ & $\begin{array}{c}\text { Chamada } \\
\text { nominal direta* }\end{array}$ & $\begin{array}{c}\text { Verificação de } \\
\text { quorum prévia }\end{array}$ & $\begin{array}{c}\text { Chamada } \\
\text { nominal direta }\end{array}$ & \\
\hline Dutra II & 3 & - & - & - & 3 \\
\hline Dutra III & 13 & - & - & - & 13 \\
\hline Vargas I & 32 & - & 2 & - & 34 \\
\hline Vargas II & 14 & 1 & 8 & 3 & 26 \\
\hline JK I & 27 & 8 & 3 & 1 & 39 \\
\hline JK II & 13 & 12 & 2 & - & 27 \\
\hline Goulart II & 1 & - & - & - & 1 \\
\hline Goulart V & 2 & - & - & - & 2 \\
\hline Goulart VI & - & 1 & - & - & 1 \\
\hline Total & 105 & 22 & 15 & 4 & 146 \\
\hline \multicolumn{6}{|c|}{$\begin{array}{l}\text { *Considera apenas votações válidas. Inclui tanto casos de passagem da lista sem } \\
\text { justificativa prévia quanto observações do emprego do método nominal sob o argumento da } \\
\text { vísivel falta de número, além das votações deliberadas por esta via procedimental em virtude } \\
\text { da aprovação de requerimentos que a solicitavam. }\end{array}$} \\
\hline \multicolumn{6}{|c|}{ Fonte: Banco de Dados Legislativos, Cebrap. } \\
\hline
\end{tabular}

Pelos números, a suposição encontra correspondência empírica. A maioria das vitórias do governo apenas com a ajuda da própria base parlamentar em decisões nominais é precedida de verificação de quorum. Com efeito, tanto nas votações de matérias rubricadas pelo próprio Executivo, quanto nas deliberações sobre temáticas apresentadas por setores governistas (tabela 3.4), as observações denotam a conexão entre o êxito da situação e as checagens de votação anteriores à passagem da lista. 
Tabela 3.4 - Tipos de vitória do governo, por coalizão, segundo a escolha procedimental, em votações nominais de matérias iniciadas por governistas (1946-1964)*

\begin{tabular}{|c|c|c|c|c|c|}
\hline \multirow{3}{*}{ Coalizão } & \multicolumn{4}{|c|}{ Tipo de vitória } & \multirow{3}{*}{ Total } \\
\hline & \multicolumn{2}{|c|}{$\begin{array}{l}\text { Apenas com os membros } \\
\text { da coalizão }\end{array}$} & \multicolumn{2}{|c|}{ Com a ajuda da oposição } & \\
\hline & $\begin{array}{c}\text { Verificação de } \\
\text { quorum prévia }\end{array}$ & $\begin{array}{c}\text { Chamada } \\
\text { nominal direta* }\end{array}$ & $\begin{array}{c}\text { Verificação de } \\
\text { quorum prévia }\end{array}$ & $\begin{array}{c}\text { Chamada } \\
\text { nominal direta }\end{array}$ & \\
\hline Dutra II & 59 & 2 & - & 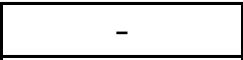 & 61 \\
\hline Dutra III & 19 & - & - & - & 19 \\
\hline Vargas I & 52 & 1 & 8 & 1 & 62 \\
\hline Vargas II & 36 & 1 & 48 & 6 & 91 \\
\hline Vargas III & 4 & - & - & - & 4 \\
\hline JK I & 82 & 35 & 18 & 5 & 140 \\
\hline JK II & 46 & 18 & 20 & 1 & 85 \\
\hline Goulart II & 1 & - & - & - & 1 \\
\hline Goulart V & 2 & - & - & - & 2 \\
\hline Goulart VI & 1 & - & 3 & - & 4 \\
\hline Total & 302 & 57 & 97 & 13 & 469 \\
\hline
\end{tabular}

*Considera apenas votações válidas de medidas assinadas por membros da coalizão em voga quando as questões seguiram à votação. Isso inclui proposições elaboradas por deputados governistas, pelas comissões presididas pelos mesmose iniciativas da própria Mesa Diretora, sempre que o diretor das sessões legislativas no momento das deliberações fosse filiado a algum partido da coalizão. No que diz respeito à prática procedimental, a tabela leva em conta tanto casos de passagem da lista sem justificativa prévia quanto observações do emprego do método nominal sob o argumento da vísivel falta de número, além das votações deliberadas por esta via procedimental em virtude da aprovação de requerimentos que a solicitavam.

Fonte: Banco de Dados Legis lativos, Cebrap.

Mais uma vez, Vargas II se faz a grande exceção ao padrão seguido pelos dados. Trata-se da única coalizão com mais vitórias precedidas de verificação de quorum justamente nas votações em que o governo só triunfou graças às contribuições da oposição, além de Goulart VI, com observações deveras pequenas para ser enquadrada num ou noutro arquétipo.

$\mathrm{Na}$ contramão, as presidências de Dutra e Kubistchek conservam ocorrências suficientes para motivar o avanço dessa investigação. A experiência de JK I, por si só, já seria particularmente interessante, dados os sinais de uso estratégico da checagem de número legal pela ala governista com vistas a se certificar do apoio cobiçado no parlamento para legislar sua agenda política. Afinal, sobre esta coalizão se aprovaria a maior fatia dos recursos 
públicos que permitiriam o Plano de Metas chegar ao alcance almejado pelo seu idealizador, que contou com a adesão da Câmara ao seu projeto desenvolvimentista.

O leitor pode estar incomodado, porém, com o fato de toda a análise subseqüente se amparar, inclusive, sobre decisões unânimes. Mantê-las nesse levantamento não é, entretanto, gratuito. Esses saldos demonstram que o governo se bastava em plenário para fazer valer as suas pretensões independentemente das contribuições da oposição, poucas vezes essenciais na passagem da agenda do Executivo. O Congresso contava com mecanismos para emperrar a pauta defendida pela situação, mas esta aparentemente fez melhor uso dos procedimentos regimentais para condicionar os resultados políticos substantivos que almejava.

Estabelecendo o ponto de corte tradicionalmente empregado pela literatura para filtrar as votações nominais com real significância do ponto de vista do conflito partidário - qual seja, um mínimo de $10 \%$ dos parlamentares votando contra o resultado final, como já discutido -, o sucesso do governo permanece predominante, 
Tabela 3.5 - Vitórias e derrotas do governo, por coalizão, em votações nominais válidas e não-unânimes (1946-1964)*

\begin{tabular}{|c|c|c|c|c|c|c|c|c|}
\hline \multirow{3}{*}{ Coalizão } & \multicolumn{7}{|c|}{ Vitórias e derrotas do governo } & \multirow{3}{*}{ Total } \\
\hline & \multicolumn{3}{|c|}{$\begin{array}{c}\text { Somente em iniciativas do } \\
\text { Executivo }\end{array}$} & \multicolumn{4}{|c|}{$\begin{array}{c}\text { Em iniciativas da sua base parlamentar na } \\
\text { Câmara }\end{array}$} & \\
\hline & Vitórias & Derrotas & Total & Vitórias & Derrotas & SI** & Total & \\
\hline Dutra II & 1 & - & 1 & 34 & 2 & 7 & 43 & 44 \\
\hline Dutra III & 2 & - & 2 & 5 & - & - & 5 & 7 \\
\hline Vargas I & 21 & 3 & 24 & 34 & 9 & 2 & 45 & 69 \\
\hline Vargas II & 16 & 4 & 20 & 69 & 7 & 1 & 77 & 97 \\
\hline Vargas III & - & - & - & 3 & - & - & 3 & 3 \\
\hline Café Filho II & - & - & - & - & - & 1 & 1 & 1 \\
\hline JK I & 24 & 3 & 27 & 85 & 7 & 4 & 96 & 123 \\
\hline JK II & 12 & - & 12 & 34 & 3 & - & 37 & 49 \\
\hline Goulart V & 1 & - & 1 & 1 & - & 1 & 2 & 3 \\
\hline Goulart VI & 1 & 1 & 2 & 3 & - & 2 & 5 & 7 \\
\hline Total & $\begin{array}{c}\mathbf{7 8} \\
(87,6 \%)\end{array}$ & $\begin{array}{c}11 \\
(12,4 \%)\end{array}$ & 89 & $\begin{array}{c}\mathbf{2 6 8} \\
(85,4 \%)\end{array}$ & $\begin{array}{c}28 \\
(8,9 \%)\end{array}$ & $\begin{array}{c}18 \\
(5,7 \%)\end{array}$ & 314 & 403 \\
\hline
\end{tabular}

*Considera apenas votações válidas. Exclui duas deliberações incapazes de se calcular a posição do partido do presidente, porque tal legenda se dividiu - uma ocorrida em Vargas I e outra, em Quadros. A título de exposição, as coalizões que apresentam todas as caselas vazias foram omitidas. **SI: Sem Informação - Diz respeito a projetos de autoria de senadores e comissões mistas, desconsiderados na classificação das iniciativas da base palrmantar do governo na Câmara Federal.

Fonte: Banco de Dados Legis lativos, Cebrap.

Contrastada às informações resumidas na tabela 3.1, a atual sintetiza o mesmo padrão de sucesso do Executivo nas decisões de suas propostas consumadas em plenário, muito embora os números absolutos sejam bem mais modestos por desconsiderarem as votações unânimes. O escore de êxito para o período total permanece alto, acima, dos 80\%, em função das derrotas, que se mantêm eventuais.

Definitivamente, a norma era a vitória - e a vitória normalmente assegurada pela própria base governista: 
Tabela 3.6 - Tipos de vitória do governo, por coalizão, em votações válidas e não-unânimes (1946-1964)*

\begin{tabular}{|c|c|c|c|c|c|c|c|}
\hline \multirow{3}{*}{ Coalizão } & \multicolumn{6}{|c|}{ Tipo de vitória } & \multirow{3}{*}{ Total } \\
\hline & \multicolumn{3}{|c|}{ Somente em iniciativas do Executivo } & \multicolumn{3}{|c|}{$\begin{array}{c}\text { Em iniciativas da sua base } \\
\text { parlamentar na Câmara }\end{array}$} & \\
\hline & $\begin{array}{c}\text { Apenas com } \\
\text { os membros } \\
\text { da coalizão }\end{array}$ & $\begin{array}{c}\text { Com a } \\
\text { ajuda da } \\
\text { oposição }\end{array}$ & Total & $\begin{array}{c}\text { Apenas com } \\
\text { os membros } \\
\text { da coalizão }\end{array}$ & $\begin{array}{c}\text { Com a } \\
\text { ajuda da } \\
\text { oposição }\end{array}$ & Total & \\
\hline Dutra II & 1 & - & 1 & 34 & - & 34 & 35 \\
\hline Dutra III & 2 & - & 2 & 5 & - & 5 & 7 \\
\hline Vargas I & 19 & 2 & 21 & 26 & 8 & 34 & 55 \\
\hline Vargas II & 7 & 9 & 16 & 17 & 52 & 69 & 85 \\
\hline Vargas III & - & - & - & 3 & - & 3 & 4 \\
\hline JK I & 20 & 4 & 24 & 65 & 20 & 85 & 109 \\
\hline JK II & 10 & 2 & 12 & 27 & 7 & 34 & 46 \\
\hline Goulart V & 1 & - & 1 & 1 & - & 1 & 2 \\
\hline Goulart VI & 1 & - & 1 & 1 & 2 & 3 & 4 \\
\hline Total & $\begin{array}{c}\mathbf{6 1} \\
(78,2 \%) \\
\end{array}$ & $\begin{array}{c}17 \\
(21,8 \%) \\
\end{array}$ & 78 & $\begin{array}{r}179 \\
(66,7 \%) \\
\end{array}$ & $\begin{array}{c}89 \\
(33,3 \%) \\
\end{array}$ & 268 & 347 \\
\hline \multicolumn{8}{|c|}{ *Considera apenas votações válidas. } \\
\hline \multicolumn{8}{|c|}{ Fonte: Banco de Dados Legislativos, Cebrap. } \\
\hline
\end{tabular}

Conforme já se anunciava, somente em Vargas II a colaboração dos opositores foi efetivamente decisiva à aprovação da agenda governamental. Por mais que o Executivo incorresse em dificuldades para formar maiorias estáveis no parlamento, não há sinais claros de êxito no seu histórico assédio à oposição, a não ser nesta coalizão específica. Muito pelo contrário: a situação e os partidos que não se alinhavam à mesma tenderam a se manter, durante quase todo o pré-64, em suas localizações ideais - ou seja: ocupando espaços distintos.

Em linhas gerais, fica nítido o exagero da literatura em frisar a ação das facções intrapartidárias enquanto elemento definidor do comportamento dos parlamentares sob a democracia populista. A despeito das conhecidas rivalidades e, mesmo, rupturas no seio das legendas da época, tão amplamente registradas pela historiografia, a conduta dos deputados da base governista não deixava o Poder Executivo refém de ajustes ad hoc para se certificar da 
passagem do seu programa político. Os aliados do presidente na Câmara dos Deputados não eram tão instáveis como os analistas usualmente afirmam.

Não questiono a existência dos rachas intrapartidários. Basta o estudo individual de cada uma das votações nas quais a preferência do governo não encontrou respaldo na sua própria base de sustentação no Legislativo para observarmos problemas de coordenação de maiorias no seio dos próprios partidos de coalizão. A questão é a irregularidade das observações, que acaba por comprometer o emprego do próprio conceito de facção ao período como um todo, como veremos a partir de agora.

\subsubsection{Votações críticas e facções partidárias}

Com base na visão usual, os presidentes que se sucederiam à frente da República de 46 manteriam contato regular com segmentos da oposição em função da constante insegurança sobre a coesão de sua coalizão formal de apoio no Legislativo. $\mathrm{Na}$ inexistência do estatuto da disciplina partidária à época, seria difícil contar com a contribuição sistemática dos deputados que se diziam governistas, dado o histórico de insubordinação de várias facções intrapartidárias, dispersas tanto na base situacionista quando no interior dos partidos de oposição.

Para entender se as vitórias do Executivo que só se materializaram graças às contribuições de opositores se deveram a rachas internos ocasionais ou duradouros em ambos os lados - isto é, tanto entre os situacionistas como entre aqueles que não se alinhavam com o governo, ao menos formalmente - é preciso, primeiro, avaliar se houve uma concentração de votos indisciplinados no seio da própria coalizão vigente durante cada uma dessas deliberações críticas. Nesta perspectiva, indisciplina seria toda manifestação parlamentar contrária aos interesses do governo. 
Iniciar tal exercício, porém, perpassa por conhecer o tamanho potencial das bases presidenciais vigentes no Congresso em cada caso. Como vimos na tabela 3.6, as dezessete iniciativas do Executivo que dependeram do subsídio oposicionista para se tornarem válidas se distribuíram entre as coalizões Vargas I e II e JK I e II.

Pelos resultados das eleições de 1950 e 1954 para a composição do Legislativo Federal, a tabela 3.7 deduz o número de cadeiras que seriam, em tese, controladas pelo Executivo na Câmara.

Tabela 3.7 - Número de assentos na Câmara dos Deputados ocupados por parlamentares governistas em Vargas e JK

\begin{tabular}{|c|c|c|c|c|c|c|c|c|}
\hline \multirow[t]{2}{*}{ Coalizão } & \multirow{2}{*}{$\begin{array}{l}\text { Partido do } \\
\text { presidente }\end{array}$} & \multirow{2}{*}{$\begin{array}{l}\text { Partidos em } \\
\text { coalizão }\end{array}$} & \multirow{2}{*}{$\begin{array}{c}\text { Eleição } \\
\text { legislativa } \\
\text { base } \\
\end{array}$} & \multicolumn{4}{|c|}{$\begin{array}{c}\text { Número de deputados } \\
\text { eleitos }\end{array}$} & \multirow{2}{*}{$\begin{array}{c}\text { Núme ro } \\
\text { total de } \\
\text { governistas }\end{array}$} \\
\hline & & & & PSD & PTB & DCD & $\mathbf{P R}$ & \\
\hline Vargas I & & PSD-PTB-PSP & \multirow{2}{*}{1950} & \multirow{2}{*}{112} & \multirow{2}{*}{52} & \multirow{2}{*}{23} & \multirow{2}{*}{10} & 187 \\
\hline Vargas II & & PSD-PTB & & & & & & 164 \\
\hline JK I & PSD & PSD-PTB-PSP-PR & \multirow{2}{*}{1954} & \multirow{2}{*}{120} & \multirow{2}{*}{59} & \multirow{2}{*}{29} & \multirow{2}{*}{18} & 226 \\
\hline JK II & PSD & PSD-PTB-PSP-PR & & & & & & 226 \\
\hline
\end{tabular}

Fonte: Banco de Dados Eleitorais, Iuperj. Elaboração própria.

Esta abordagem é uma simplificação grosseira do desenvolvimento realizado por Wanderley Guilherme dos Santos (2003) para pensar a hipótese da insuficiência da aliança entre pessedistas e trabalhistas a partir de meados dos anos 1950, quando uma conformação de forças "minimamente vencedora" já não estaria mais ao alcance de PSD e PTB, dependentes de outros reforços para afiançar a aprovação dos interesses do governo no plenário $^{58}$.

Realmente, seria ingênuo conjecturar o apoio incondicional e sistemático dos representantes eleitos por partidos da coalizão presidencial apenas por estes números, até

\footnotetext{
${ }^{58}$ Cf. SANTOS, 2003, op. cit.
} 
mesmo porque não se faz o controle da migração partidária, embora a troca de legenda se revele uma opção rara durante a democracia populista ${ }^{59}$.

Para os propósitos do raciocínio em andamento, todavia, a informação é suficiente. Em Vargas II, os membros da coalizão superam o valor determinado pelo regimento como quorum mínimo para validação das votações levadas a cabo durante as sessões legislativas apenas em 11 “cabeças” (164 homens para 153 votos mínimos) ${ }^{60}$. Nesta conjuntura, contar com auxílios externos não soa um luxo, mas uma necessidade perene. Kubistchek, diferentemente, contaria com folga relativa, reunindo muito mais quadros partidários no intuito de formar uma base parlamentar sólida ao longo da vigência do seu mandato.

Isto posto, é hora de revisitar os resultados por partidos e coalizões observados naquelas dezessete votações críticas relativas a iniciativas do Poder Executivo que só foram aprovadas com a ajuda da oposição. Para facilitar a compreensão da próxima tabela, que sistematiza o referido teste, é melhor discutir coluna a coluna. As primeiras três delas codificam as votações segundo a coalizão em que ocorreram, a sua seqüência temporal e a maioria simples, exigida para todas as matérias em questão. No caso de Vargas, eram necessários 78 votos para que os projetos considerados fossem aprovados. Caso contrário, a decisão estava adiada. Em JK, esse número sobe para 83.

A quarta coluna da tabela indica a posição majoritária do partido do presidente em função do universo de deliberações estudado neste momento - as iniciativas do Executivo. Conforme foi discutido no início deste capítulo, a preferência do governo nestas matérias foi deduzida a partir da manifestação que se fez maior no seio da legenda que elegeu o chefe do Executivo. A adesão da base parlamentar à referida escolha governista pode ser conferida nas

\footnotetext{
${ }^{59}$ Sistematizei a troca de legenda ao longo do pré-64, observando que menos de $10 \%$ dos deputados recorriam a essa possibilidade. Como o escore é muito baixo, não se faz necessário ajustá-lo nesta investigação, já que pouco tais informações pouco contribuiriam ao exercício em andamento. Os resultados constam em ZULINI (2010).

${ }^{60}$ Vale retomar a nota 32 , à p. 57, que apresenta o quorum mínimo em vigor a cada legislatura da época.
} 
colunas seguintes, que dividem os membros da coalizão em dois grupos: os disciplinados são somados na categoria $n D$ e os indisciplinados, na $n I$.

Por fim, as últimas restantes da tabela totalizam 1) os votos disciplinados da base do governo em cada votação; 2) os números da indisciplina no interior da coalizão; 3) a soma de ambas as preferências observadas; 4) o número de votos que faltaram para a coalizão vencer com as suas próprias forças e 5) a soma das contribuições da oposição, nesta ordem. 
Tabela 3.8 - Distribuição das preferências entre os partidos que compõem a coalizão nas 17 votações em que as iniciativas do Executivo só se fizeram aprovadas graças ao apoio da oposição

\begin{tabular}{|c|c|c|c|c|c|c|c|c|c|c|c|c|c|c|c|c|}
\hline \multirow{3}{*}{ Coalizão } & \multirow{3}{*}{ Votação } & \multirow{3}{*}{\begin{tabular}{|c|} 
No \\
mínimo \\
para \\
vitória
\end{tabular}} & \multirow{3}{*}{\begin{tabular}{|c|} 
Posição \\
majoritária do \\
partido do \\
presidente
\end{tabular}} & \multicolumn{8}{|c|}{ Partidos } & \multirow{3}{*}{$\begin{array}{l}\text { Total de votos } \\
\text { disciplinados } \\
\text { da base do } \\
\text { governo }\end{array}$} & \multirow{3}{*}{$\begin{array}{l}\text { Total de votos } \\
\text { indisciplinados } \\
\text { da base do } \\
\text { governo }\end{array}$} & \multirow{3}{*}{\begin{tabular}{|c|} 
Total de \\
votos da \\
base do \\
governo
\end{tabular}} & \multirow{3}{*}{$\begin{array}{c}\text { Votos } \\
\text { faltantes } \\
\text { para o } \\
\text { quorum }\end{array}$} & \multirow{3}{*}{$\begin{array}{c}\text { Total de } \\
\text { contribuições } \\
\text { da oposição }\end{array}$} \\
\hline & & & & \multicolumn{2}{|c|}{ PSD } & \multicolumn{2}{|c|}{ PTB } & \multicolumn{2}{|c|}{ PSP } & \multicolumn{2}{|c|}{ PR } & & & & & \\
\hline & & & & nD* & $\mathbf{n I} * *$ & $\mathrm{nD}$ & nI & $\mathrm{nD}$ & nI & nD & nI & & & & & \\
\hline \multirow{2}{*}{ Vargas I } & 1 & \multirow{11}{*}{78} & Sim & 30 & 37 & 26 & 1 & 18 & 3 & & & 74 & 41 & 115 & 4 & 17 \\
\hline & 2 & & Sim & 31 & 38 & 22 & 11 & 10 & 1 & & & 63 & 50 & 113 & 15 & 11 \\
\hline \multirow{9}{*}{ Vargas II } & 1 & & Sim & 35 & 25 & 28 & 8 & & & & & 63 & 33 & 96 & 15 & 31 \\
\hline & 2 & & Não & 48 & 10 & 27 & 5 & & & & & 75 & 15 & 90 & 3 & 55 \\
\hline & 3 & & Não & 45 & 15 & 28 & 3 & & & & & 73 & 18 & 91 & 5 & 55 \\
\hline & 4 & & Não & 47 & 8 & 16 & 12 & & & & & 63 & 20 & 83 & 15 & 44 \\
\hline & 5 & & Não & 50 & 12 & 13 & 10 & & & & & 63 & 22 & 85 & 15 & 51 \\
\hline & 6 & & Sim & 41 & 21 & 17 & 9 & & & & & 58 & 30 & 88 & 20 & 40 \\
\hline & 7 & & Sim & 45 & 16 & 19 & 12 & & & & & 64 & 28 & 92 & 14 & 16 \\
\hline & 8 & & Sim & 43 & 8 & 23 & 8 & & & & & 66 & 16 & 82 & 12 & 19 \\
\hline & 9 & & Sim & 54 & 16 & 21 & 6 & & & & & 75 & 22 & 97 & 3 & 36 \\
\hline \multirow{4}{*}{ JK I } & 1 & \multirow{6}{*}{83} & Sim & 51 & 11 & 19 & 18 & 6 & 4 & 5 & 2 & 81 & 35 & 116 & 2 & 37 \\
\hline & 2 & & Não & 44 & 11 & 20 & 16 & 8 & 3 & 7 & 0 & 79 & 30 & 109 & 4 & 50 \\
\hline & 3 & & Não & 38 & 21 & 21 & 21 & 4 & 5 & 2 & 4 & 65 & 51 & 116 & 18 & 40 \\
\hline & 4 & & Sim & 41 & 9 & 20 & 18 & 10 & 2 & 2 & 1 & 73 & 30 & 103 & 10 & 25 \\
\hline \multirow{2}{*}{ JK II } & 1 & & Sim & 48 & 12 & 4 & 34 & 7 & 6 & 7 & 4 & 66 & 56 & 122 & 17 & 22 \\
\hline & 2 & & Sim & 43 & 23 & 5 & 39 & 6 & 11 & 8 & 2 & 62 & 75 & 137 & 21 & 28 \\
\hline
\end{tabular}

*nD: Número de votos disciplinados em relação à posição majoritária do partido do presidente. **NI: número de votos indisciplinados em relação ao partido do presidente. 
Os dados realmente revelam a dispersão dos quadros partidários. Para além dos pessedistas, com uma tendência maior à concentração de votos numa determinada posição, todas as demais legendas denotam a dificuldade de compor maiorias internamente. Em contrapartida, a ajuda dos oposicionistas sinaliza, a princípio, para a sistematicidade. Contribuições de fora da base se mantêm praticamente sempre elevadas, em número muito superior ao que se fazia imprescindível ao governo.

A dúvida imediata contempla justamente a autoria desse subsídio externo. A fim de equalizá-la, o gráfico a seguir contrasta a média do número total de votos oriundos das legendas alheias à base parlamentar de apoio ao Executivo em voga com a soma média das contribuições da bancada udenista em cada uma das 17 votações críticas, válidas e nãounânimes, nas quais a preferência da posição majoritária do partido do chefe do Executivo só se fez vitoriosa em função das contribuições de membros da oposição, totalizadas na tabela anterior. Para todas as coalizões, as primeiras barras mostram o número médio de votos oposicionistas necessários à vitória que seria alcançada com o socorro dos oposicionistas, ao passo que as barras intermediárias apresentam o número médio das contribuições dos udenistas, enquanto as últimas barras divulgam o número médio do apoio oriundo de outros partidos de oposição. 


\section{Gráfico 3.2 - Contribuição média de setores da oposição em votações válidas e não- unânimes sobre matérias iniciadas pelo Executivo, vitorioso com a ajuda da oposição}

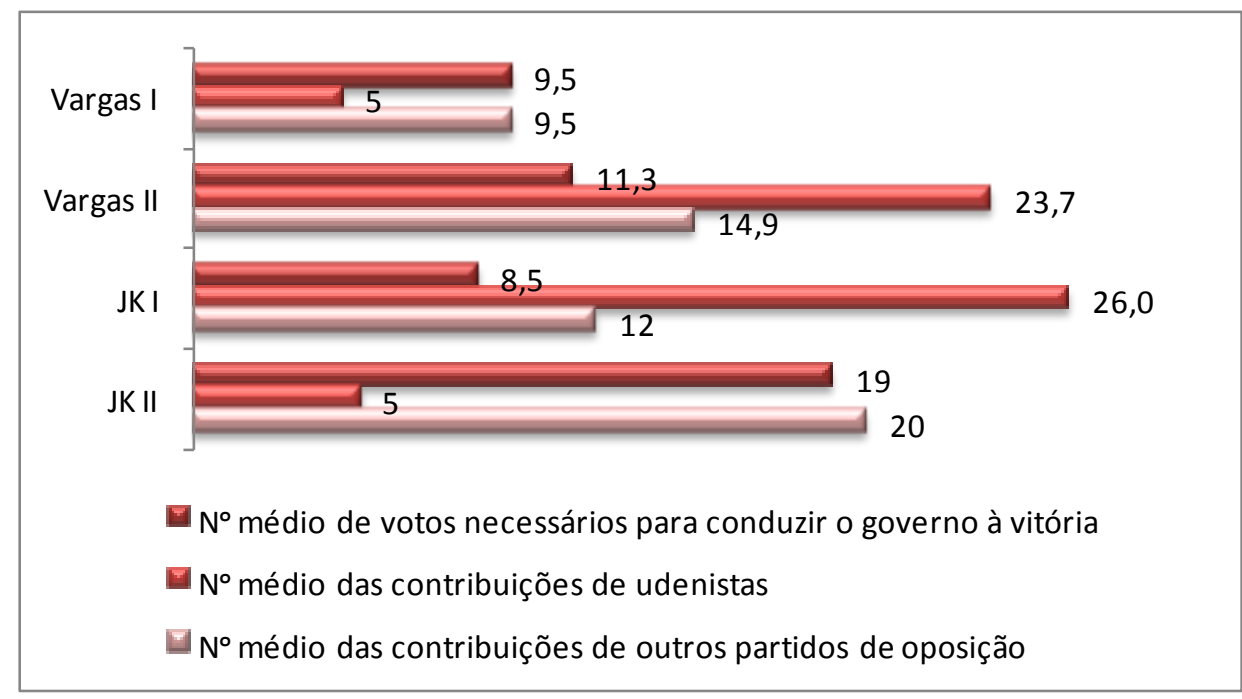

Fonte: Banco de Dados Legislativos, Cebrap.

A ilustração é categórica: as manifestações dos filiados à UDN constituíram a base, por excelência, do êxito do Executivo na Câmara dos Deputados em Vargas II e JK I, quando a coalizão não se mostrava capaz de assegurar, por si só, a vitória da posição estimada pelo governo nas decisões em andamento no plenário. Na vigência das referidas bases parlamentares, a sigla ultrapassaria os demais partidos da oposição em número de votos favoráveis à situação no poder, como demonstram também as observações desagregadas referentes às 17 deliberações que deram origem ao gráfico 3.2, analisadas, individualmente, no Anexo $\mathrm{M}^{61}$.

Todavia, o exame qualitativo de cada uma destas decisões não aponta a regularidade dos parlamentares em seu auxílio ao governo. Os udenistas que dirigiam esses votos capitais para a situação no poder variavam conforme as votações se seguiam. Muito embora seja bastante plausível supor que se tratasse de uma estratégia, exatamente para preservar o acordo de apoio tácito à passagem da agenda presidencial e não incorrer em mal-estar com o próprio eleitorado, não há como se comprovar, pelos dados, a agência de facções agindo em plenário.

\footnotetext{
${ }^{61}$ Vide p. 152.
} 
Como vimos no capítulo 1 , o conceito de facciosismo requer alguma sazonalidade para se fazer indubitável. Infelizmente, os componentes das várias cisões intrapartidárias aludidas na literatura são numericamente muito diminutos para se assumir tal elenco como uma proxy capaz de verificar se as contribuições dos opositores, tomadas como dispersas, estivessem encobertas por um rodízio tático de deputados nas votações.

No exame das 89 decisões válidas e não-unânimes relativas a matérias iniciadas por membros da base governista na Câmara que dependeram do socorro da oposição para serem aprovadas, esta ponderação se mantém. Com efeito, o impasse em construir maiorias dentro dos próprios quadros é uma realidade para os partidos da coalizão presidencial no parlamento, conforme revelam os dados individuais das referidas deliberações, disponíveis no Anexo $\mathrm{N}^{62}$. Mais uma vez, o apoio dos udenistas se destaca na conquista dos saldos tencionados pela situação, a ver pelos números apresentados pelo gráfico 3.3.

\section{Gráfico 3.3 - Contribuição média dos udenistas em votações válidas e não-unânimes sobre matérias iniciadas por governistas, vitoriosos com a ajuda da oposição}

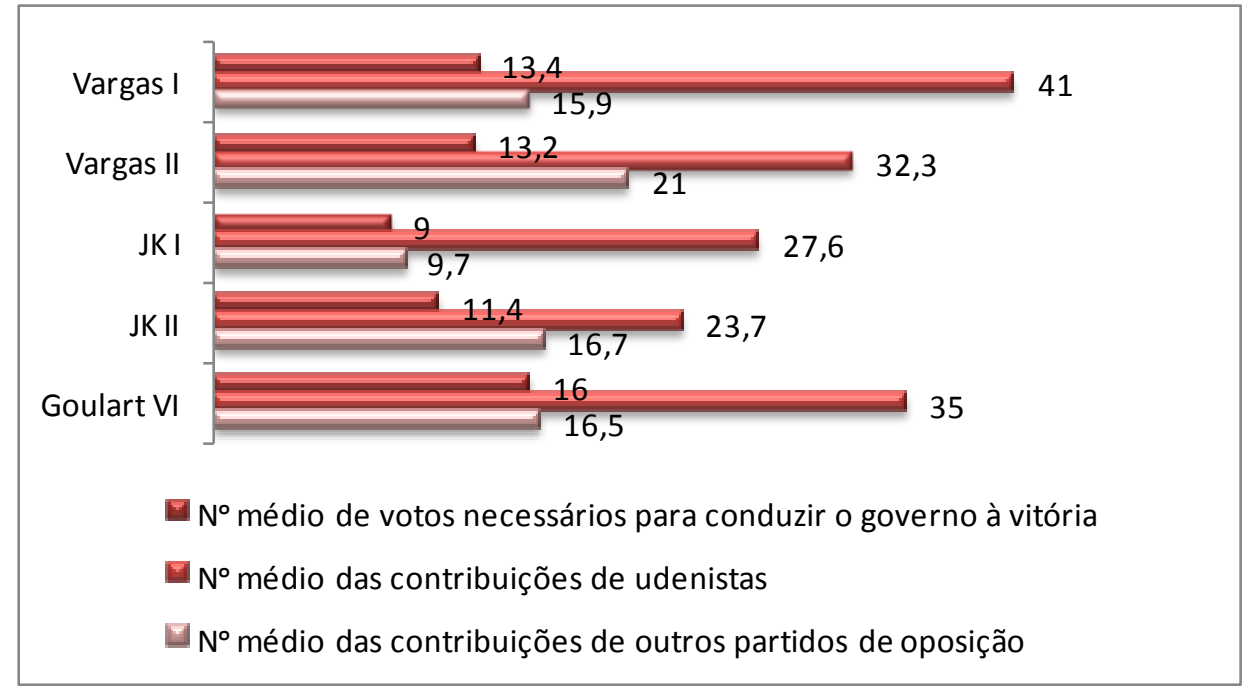

Fonte: Banco de Dados Legislativos, Cebrap.

Em todas as cinco coalizões em que as contribuições da oposição foram essenciais para o êxito governista, a ajuda da UDN sempre excederia, sozinha, o número de

\footnotetext{
${ }^{62}$ Como já vimos, este grupo de votações inclui duas deliberações realizadas durante a administração de Goulart. Como o exercício anterior já foi suficiente para entender a lógica interpretativa da tabela, omito sua continuidade para o caso desta gestão, embora traga as suas observações no mesmo anexo. Cf. p. 153.
} 
manifestações necessário para a vitória almejada ${ }^{63}$. Entretanto, apenas sob Vargas II haveria um grupo de deputados udenistas que votaria sistematicamente com o governo.

Doze representantes do maior partido de oposição da época votariam com o governo em pelo menos 20 das 52 decisões nas quais a coalizão presidencial necessitou de apoios externos para aprovar iniciativas assinadas por seus membros. Dentre os mais assíduos, figuras expoentes da Banda de Música, destacada na literatura como o reduto dos udenistas mais radicais no embate político diário com o governo. Observe:

Tabela 3.9 - Relação de udenistas que mais votaram com o governo em Vargas II

\begin{tabular}{|l|l|c|}
\hline \multicolumn{1}{|c|}{ Deputado } & \multicolumn{1}{|c|}{ Classificação* } & $\begin{array}{c}\text { No de votações } \\
\text { em que ajudou o } \\
\text { governo }\end{array}$ \\
\hline \hline Afonso Arinos & Banda de Música/Liberais históricos & 28 \\
\hline Aliomar Baleeiro & Banda de Música & 24 \\
\hline Ernani Satyro & Banda de Música & 30 \\
\hline João Agripino Filho & Nacionalista & 29 \\
\hline José Bonifácio & Banda de Música/Coronelismo & 29 \\
\hline Oswaldo Trigueiro & Liberais Históricos & 37 \\
\hline Alberto Deodato & Liberais históricos & 28 \\
\hline Bilac Pinto & Banda de Música (anticomunismo radical) & 31 \\
\hline Adahil Barreto & Bossa Nova & 25 \\
\hline Virgilio Tavora & Chapas-Brancas/Bossa Nova & 20 \\
\hline Rondon Pacheco & Obscuro & 24 \\
\hline Raimundo Padilha & Linha Dura & 26 \\
\hline \multicolumn{2}{|r|}{$*$ Segue os rótulos atribuídos por Benevides (1981a) a cada parlamentar. } \\
\hline \multicolumn{2}{|l|}{ Fonte: Banco de Dados Legislativos, Cebrap. } \\
\hline
\end{tabular}

Confrontando esses dados com o gráfico precedente, que assinalava ser da ordem de 13,2 o número médio de votos capitais que a segunda coalizão de forças formalizada durante a gestão de Getúlio normalmente precisou contar para obter do plenário o endosso de suas medidas prioritárias, realmente parece fazer sentido falar em facções parlamentares em Vargas II.

\footnotetext{
${ }^{63}$ O Anexo O discrimina as contribuições dos udenistas em relação aos demais partidos de oposição que possibilitaram a aprovação de parte da agenda do Executivo em votações críticas, nas quais a indisciplina no interior da coalizão teria sido capaz de comprometer o programa político do governo. Oitenta e nove deliberações podem ser acompanhadas individualmente à p. 157.
} 
Todavia, a capacidade governativa à República de 46, no geral, independeu do socorro de setores oposicionistas nas votações nominais então ocorridas - e sob esta constatação fundamento a minha crítica à literatura disponível até o momento. É muito possível que cisões intrapartidárias reveladas no seio da oposição se manifestassem em favor dos interesses do governo. Apenas em Vargas, porém, há informações suficientes para se admitir que essa campanha pró-Executivo teve real relevância para os frutos políticos então obtidos. No mais, as cisões no interior das legendas, sejam ou não atreladas à coalizão, significaram muito pouco enquanto ameaça efetiva para as pretensões presidenciais em jogo no pré-64.

As tabelas a seguir revelam, inclusive, que somente em Vargas e JK o respaldo da base parlamentar de apoio ao chefe do Executivo se esfacelou no decurso do governo, quando se consideram tanto a apreciação de iniciativas legislativas do dirigente do país (tabela 3.10) quanto a decisão de proposições assinadas por seus correligionários na Câmara (tabela 3.11). A ajuda de deputados filiados aos partidos de oposição aumenta em importância apenas nestes recortes, diferentemente da dinâmica inerente às demais composições firmadas ao longo do pré-64. Dutra sequer precisaria deste tipo de auxílio. Mesmo Juscelino retomaria o fôlego do início do mandato no seu último ano de gestão pública.

Tabela 3.10 - Êxito do governo em matérias iniciadas pelo Executivo ao longo do mandato presidencial (1946-1964)*

\begin{tabular}{|c|c|c|c|c|c|c|c|c|c|c|c|}
\hline \multirow[b]{2}{*}{ Mandato } & \multicolumn{2}{|c|}{$1^{\circ}$ ano } & \multicolumn{2}{|c|}{$2^{\circ}$ ano } & \multicolumn{2}{|c|}{$3^{\circ}$ ano } & \multicolumn{2}{|c|}{$4^{\circ}$ ano } & \multicolumn{2}{|c|}{$5^{\circ}$ ano } & \multirow[b]{2}{*}{ Total } \\
\hline & VB* & VOP** & VB & VOP & VB & VOP & VB & VOP & VB & VOP & \\
\hline Dutra & - & - & - & - & - & - & 1 & - & 2 & - & 3 \\
\hline Vargas & 12 & 1 & 1 & - & 13 & 10 & - & - & - & - & 37 \\
\hline $\mathrm{JK}$ & 7 & - & 6 & - & 7 & 4 & 4 & - & 6 & 2 & 36 \\
\hline Goulart & - & - & - & - & 2 & - & - & - & - & - & 2 \\
\hline Total & 19 & 1 & 7 & - & 22 & 14 & 5 & - & 8 & 2 & 78 \\
\hline
\end{tabular}


Tabela 3.11 - Êxito do governo em matérias iniciadas por governistas ao longo do mandato presidencial (1946-1964)*

\begin{tabular}{|c|c|c|c|c|c|c|c|c|c|c|c|}
\hline \multirow{2}{*}{ Mandato } & \multicolumn{2}{|c|}{$1^{\circ}$ ano } & \multicolumn{2}{|c|}{$2^{\circ}$ ano } & \multicolumn{2}{|c|}{$3^{\circ}$ ano } & \multicolumn{2}{|c|}{$4^{\circ}$ ano } & \multicolumn{2}{|c|}{$5^{\circ}$ ano } & \multirow{2}{*}{ Total } \\
\hline & VB* & VOP** & VB & VOP & VB & VOP & VB & VOP & VB & VOP & \\
\hline Dutra & - & - & 4 & - & 16 & - & 14 & - & 5 & - & 39 \\
\hline Vargas & 15 & 4 & 4 & - & 7 & 53 & 17 & 3 & 3 & - & 106 \\
\hline $\mathrm{JK}$ & 33 & 7 & 21 & 5 & 11 & 8 & 17 & 5 & 10 & 2 & 119 \\
\hline Goulart & - & - & - & - & 2 & 2 & - & - & - & - & 4 \\
\hline Total & 48 & 11 & 29 & 5 & 36 & 63 & 48 & 8 & 18 & 2 & 268 \\
\hline
\end{tabular}

* Considera apenas votações válidas e não-unânimes de medidas assinadas por membros da coalizão em voga quando as questões seguiram à votação. Reiterando, is so inclui proposições elaboradas por deputados governistas, pelas comissões presididas pelos mesmose iniciativas da própria Mesa Diretora, sempre que o diretor das sessões legislativas no momento das deliberações fosse filiado a algum partido da coalizão. **VB: Vitória com a própria base. ***VOP: Vitória como apoio da oposição.

Fonte: Banco de Dados Legis lativos, Cebrap.

Sob esta perspectiva, a explicação de Amorim Neto e Santos perde, definitivamente, suporte empírico a nível geral. À exceção da presidência varguista, a tese do enfraquecimento do apoio despendido pela coalizão em prol do governo no decurso do tempo não encontra lugar na República populista.

$\mathrm{Na}$ realidade, toda a análise precedente questiona muito do pouco que ainda sabemos sobre 46-64. Embora o período adentre para a história política do país como uma turbulenta sucessão de crises a ameaçar a continuidade democrática, os trabalhos legislativos prosseguiram com relativa tranqüilidade - e o propalado desafio administrativo mitigou ao confronto menos rebuscado com a realidade empírica. Na contramão do teoricamente descentralizado decision-making vigente à época, a arregimentada discricionariedade do coordenador dos trabalhos legislativos na Câmara. Ao elevado custo informacional de se arquitetar maiorias num plenário dividido, a disponibilidade de mecanismos institucionais para se dimensionar a divisão de preferências. Neste modelo de estímulos opostos, faccionalismo e capacidade decisória são regados ao tempero da tensão regional. Não por 
acaso, a abertura do Congresso ao localismo e as consequiências imediatas para a governabilidade do país constituem o último ponto deste exercício explicativo.

\subsection{A construção de maiorias em políticas de efeito circunscrito}

Quando se trata de 46-64, há certo determinismo latente às avaliações usuais sobre a tônica do comportamento parlamentar então vigente. Segundo a literatura, os representantes seguiriam uma tradição marcadamente paroquialista, preocupados que eram em recompensar seus redutos eleitorais com vistas à almejada renovação do mandato eleitoral, responsável pela sua manutenção no poder. O comprometimento com políticas universalistas apenas ganharia consistência na apreciação das questões mais relevantes para o governo, ficando o individualismo clientelista dos legisladores temporariamente em stand by, até nova ordem.

Com efeito, o próprio passado administrativo do país condicionaria a propensão dos parlamentares ao engajamento em políticas de efeito circunscrito tal se fazia arraigada a privatização local do poder público, no Brasil, desde os tempos do Império. A restauração liberal, em 1945, não se mostraria capaz de exterminar certas práticas indesejáveis, que já teriam adentrado para o "folclore" dos nossos governantes. O regionalismo permaneceria o maior norteador da tomada de decisão dos representantes, sobrepujando inclinações ideológicas e/ou programáticas.

A meta desta seção é dimensionar a fração lúdica e a carga de realidade da crônica ora descrita. Basicamente, o foco da pesquisa a partir de agora se fixará no exame do processo decisório restrito a medidas específicas, visando sondar a ocorrência de algum padrão diferente do apreendido no capítulo anterior, preocupado com o trâmite de matérias relevantes para o Poder Executivo e sua base parlamentar. Afinal, a investigação da conduta do plenário na Câmara Federal em questões paroquialistas se consagrou na literatura como intercurso, por excelência, de quaisquer análises voltadas à compreensão da ação dos legisladores no pré-64. 


\subsubsection{O debate regionalista em plenário}

Seria imprudente conduzir este estudo sobre o padrão de apoio e conflito entre governo e parlamento no pré-64 sem enveredar pelo exame da questão regional. A relevância do estudo das clivagens territoriais para o entendimento da política brasileira durante a democracia populista não constitui argumento novo. Foi taxativamente defendido por Souza (2006), que alertou sobre a subestimação corrente do federalismo e do regionalismo como conceitos analíticos. A seu ver, não se poderia desconsiderar o papel das regiões e dos estados ante a política central, uma vez que eles formam sistemas de poder, independentemente de serem reconhecidos como tais dentro de um sistema de governo (SOUZA, 2006, p. 7). Deste modo, as diversidades de poder regional se manifestariam, inclusive, nas próprias políticas federais, mesmo naquelas ostensivamente designadas a estimular a integração nacional (Ibid., p. 8).

Tal conclusão não parte, porém, de um exame dos projetos que tramitaram nas casas legislativas federais, até mesmo porque a autora defende que, à época, o sistema decisório se mostrava fortemente centralizado na burocracia federal, em detrimento dos partidos e do Congresso (Ibid, p. 21). Aludindo à "posição independente de barganha" que as bancadas regionais gozariam na política decisória brasileira, Souza comenta, em linhas bastante gerais, que grande parte das deliberações nacionais se dava através de acordos informais entre membros do ramo executivo e governadores dos estados importantes das várias regiões ${ }^{64}$. Saída condizente com a chamada "barganha estatista", que equilibrava o convívio entre os dois brasis por meio da negociação dos frutos do desenvolvimento entre as elites regionais,

\footnotetext{
${ }^{64}$ Segundo a autora, tais negociações abarcavam desde a designação de sucessores presidenciais à alocação de créditos (SOUZA, 2006, p. 30). As medidas econômico-financeiras, na realidade, teriam sido mesmo subtraídas da esfera político-partidária e do Congresso, mas não necessariamente da influência de grupos regionais, em especial no caso dos estados mais ricos, para os quais a burocracia teria um caráter "altamente poroso" (Ibid., p. $31)$.
} 
deixando o modelo de desenvolvimento intacto ${ }^{65}$. Reconhecendo o caráter conjectural que norteia vários dos seus apontamentos, porém, a analista deixaris um convite aberto a pesquisas futuras ${ }^{66}$.

Embora Santos (2003) também se preocupe em trazer o federalismo para o corpo de conceitos analíticos a ser explorado no exame do período 1946-64, seu trabalho acaba por discutir as bancadas regionais privilegiando a questão da "justiça federativa da representação" - isto é, a proporção entre colégio eleitoral e representação política a nível federal. Como a Carta de 1946 manteve, em seu art. 58, a representação proporcional como método de conversão de votos em cadeiras na Câmara dos Deputados, beneficiando, na prática, os estados mais atrasados no tocante à estrutura agrária (SOUZA, 2006, p. 23-24), o autor procura checar "se estaria configurando no parlamento uma situação em que a minoria econômica teria poder de veto em relação à maioria" (SANTOS, 2003, p. 115). A partir do cálculo das taxas de representação estaduais e do recurso ao índice de Gini, Santos considera "improcedente" a tese divulgada pela literatura federativa, mas não estende seu exame para o estudo das bancadas estaduais durante as deliberações efetivas em plenário ${ }^{67}$.

No entanto, o acompanhamento das decisões ratificadas pelo parlamento no período pré-64 viabiliza complementar este teste, especialmente através da distinção do conteúdo das matérias objeto de dissenso na fase final da deliberação. Admitindo que as federações, apresentando mais pontos de veto no processo decisório em relação aos sistemas unitários, criem instituições a dificultar a distribuição original de competências e, mais, tornem os governos subnacionais veto players em matérias que comprometam seus interesses (ARRETCHE, 2009), é possível classificar as proposições em votação considerando o seu

\footnotetext{
${ }^{65}$ Tal barganha refletiria um balanço cuidadosamente estruturado entre a dependência do país das regiões mais industrializadas e costeiras e as demandas do interior e dos setores mais ruralizados por influência política (SOUZA: 2006, p. 30).

${ }^{66}$ Nas suas palavras, "podemos [...] apontar para alguns traços gerais da dinâmica partidária e regional no quadro decisório, a serem desenvolvidos por pesquisas". Cf. SOUZA, 2006, p. 31.

${ }^{67} \mathrm{Na}$ avaliação do autor, o funcionamento do parlamento dependia de coalizões partidárias, para além das regiões, respeito às minorias de opinião e negociações entre bancadas estaduais (SANTOS, 2003, p. 119).
} 
impacto sobre os entes federados e avaliar, comparativamente, o comportamento das bancadas estaduais nestes casos e em situações "neutras" - aquelas deliberações sobre matérias que não afetam seus interesses. $\mathrm{O}$ esperado seria justamente um padrão diferenciado no comportamento dos parlamentares sob os auspícios de questões regionais, sobretudo naquelas de cunho orçamentário, dada a marcante tensão social que se prolonga durante a República de 1946 pela reprodução da condição de miséria dos municípios brasileiros e a debilidade financeira da maior parte das unidades federativas. Dependentes do arbítrio do poder central, os governos subnacionais não tinham em sua defesa outro recurso que a representação política no Congresso nacional (SANTOS, 2003, p. 56).

Uma primeira consulta aos polêmicos debates de medidas localistas registrados nos Diários da Câmara dos Deputados potencializa essa interpretação. As prolongadas exposições ensaiadas na tribuna realmente dão a impressão de que o regionalismo configurava o grande catalisador do facciosismo intrapartidário então disseminado. De fato, dois dispositivos constitucionais seriam estrategicamente acionados para amparar os embates levados a cabo na Casa, tornando a publicação verdadeira crônica de contendas regionalistas.

\subsubsection{A disputa por recursos escassos e o art. 67}

"tenho minhas dúvidas quanto ao fato de abrir um crédito para a realização de temporadas teatrais na capital da República, quando isso é atribuição precípua da municipalidade do Distrito Federal"

(Barreto Pinto, DCD, 29/07/1948, pp. D014160473.TIF)

Esta foi a provocação deferida pelo udenista Barreto Pinto aos demais deputados durante a votação do requerimento $\mathrm{n}^{\mathrm{o}}$ 176/1948, que solicitava a remessa às Comissões de Constituição e Justiça e de Educação e Cultura do Projeto n ${ }^{o}$ 521-A/1948, autorizando o Governo Federal a conceder subvenção à Prefeitura do Distrito Federal para a realização de uma temporada lírica. Mesmo não se tratando de uma medida federativa, na medida em que a 
definição se reserva às relações políticas e econômicas entre os estados e o poder central ${ }^{68}$, a proposição é discutida a partir da revisão das diferentes atribuições dos governos central e subnacionais.

Neste ponto, a constitucionalidade das matérias que tramitavam na Câmara Federal visando destinar investimentos da União a determinadas localidades ficava, muitas vezes, dependente da interpretação realizada pelos membros da Comissão de Constituição e Justiça (CCJ) sobre o artigo 67, parágrafo $2 .^{\circ}$ da Carta de 1946.

Basicamente, este parágrafo estabelecia como competência exclusiva do Presidente da República a iniciativa das leis que criassem empregos em serviços existentes, aumentassem vencimentos ou modificassem, no decurso de cada legislatura, a lei de fixação das forças armadas, "ressalvada a competência da Câmara dos Deputados, do Senado e dos Tribunais Federais, no que concerne aos respectivos serviços administrativos" ${ }^{\text {69 }}$.

Apesar de várias proposições ferirem este preceito constitucional, nem sempre a CCJ apontava tal improbidade, conforme lembra o deputado Celso Branco (UDN/SC) ao questionar o parecer dado pela comissão, na figura de seu relator, o deputado Unírio Machado (PTB/RS), ao projeto $\mathrm{n}^{\circ}$ 1490, de 1956, que criava um posto de Arrecadação no município de Itapiranga, Estado de Santa Catarina.

$\mathrm{Na}$ época, Machado avaliou se tratar de uma matéria anticonstitucional, que infringia o art. 67, parágrafo $2 .^{\circ}$ da Carta de 1946, uma vez que “a doação de um posto de Arrecadação envolve, por via de conseqüência, a criação
de cargos novos ou empregos em serviço já existente, pois, que subordinado à
Delegacia Fiscal do Estado de Santa Catarina. E, desta forma, estará burlado o
princípio constitucional da iniciativa privativa do Presidente da República que se
verá obrigado a prover o novo serviço nomeando novos funcionários necessários"70.

\footnotetext{
${ }^{68}$ Cf. ARRETCHE, 2009; SANTOS, 2003; STEPHAN, 1999; SOUZA, 2006.

${ }^{69}$ Cf. Constituição dos Estados Unidos do Brasil, de 18 de setembro de 1946, art. 67, § 2. .

${ }^{70}$ DCD, 23/04/1957, p. D012070553.TIF.
} 
Não é esta interpretação que surpreende Celso Branco, mas o fato da mesma comissão adotar "critérios diametralmente opostos" para proposições idênticas em trâmite na Casa, como o projeto n. ${ }^{\circ}$ 2.266, de 1952, que cria a Universidade do Pará, com sede em Belém, capital do Estado, e integrada ao Ministério da Educação e Saúde, Diretoria do Ensino Superior, considerado constitucional embora contivesse, como lembra Branco, os mesmos vícios apontados pela CCJ quando tratou do Projeto 1.490 .

No entanto, o tratamento distinto fica mais patente no relatório emitido pela mesma comissão e, mais ainda, preparado pelo próprio Unírio Machado, ao projeto nº 2.055, de 1952, que autoriza o Poder Executivo a instalar agências postais nas localidades de Taboleiro dos Martins, Município de Maceió, Alagoas:

\begin{abstract}
"Pela constitucionalidade da proposição. Semelha ela a inúmeras outras já havidas por constitucionais pela Comissão de Constituição e Justiça. A tese vencedora é de que inexiste o serviço, tendo o Congresso iniciativa para criá-lo, sem que isso importe em desconhecer a redação constante do $\S 2{ }^{\circ}$ do artigo 67 da constituição Federal. Os usuários de determinado serviço público federal é que lhe atestam a existência. Além do mais, o que se objetiva é instituir serviço e não criar cargo, sendo aquele um todo deste é parte, não sendo compatível com a Constituição extensão analógica de uma proibição que incide sobre o menos para que recaia também para o mais. Rematado absurdo considerar que determinado serviço 'existe' em determinado município porque realmente só existe em outros municípios do País e somente aos respectivos municípios beneficia. O município tem categoria constitucional, sendo base ou unidade da Federação, principalmente para localização da atividade administrativa federal. Observe-se, ainda, que a preterição dos municípios configura atentado ao preceito constitucional da igualdade de todos perante a lei, além de transgredir frontalmente o artigo 31 do Código Supremo:

'A União, aos Estados, ao Distrito Federal e aos Municípios é vedado:

I - Criar distinções entre brasileiros ou preferências em favor de uns contra os outros Estados ou Municípios'.

Quanto ao art. 1. ${ }^{\circ}$, a exemplo do que reiteradamente tem sido proposto e aceito na Comissão de constituição e Justiça, entendemos que a linguagem da lei deve ser imperativa atestando categoricamente a existência do serviço depois de sua vigência. Assim, o artigo $1 .^{\circ}$ deve ter esta redação:

'Ficam criadas agências postais nos Municípios de Taboleiro dos Martins, Maceió, Caruaru, São José da Lage, em Alagoas' [...]” (Idem).
\end{abstract}

Daí Celso Branco esperar que o plenário rejeitasse o parecer da CCJ ao projeto 1.490, de 1956, mantendo a orientação que estava sendo seguida há muito tempo, em decisões repetidas.

O mais curioso é que ambos os casos citados por Branco em que a CCJ se pronunciou pela constitucionalidade - isto é, os PLs. n 2.266/1952 e 2.055/1952 - tratam de municípios 
nordestinos, tendo o primeiro sido aprovado sem divergências aparentes, quando se considera a inexistência de pedidos de verificação de votação durante as deliberações desta matéria ${ }^{71}$. Tampouco a reclamação do tratamento distinto que a Casa dava aos diferentes entes federados não se mostra pouco usual entre as exposições dos oradores, à revelia do preceito constitucional estabelecido no artigo 31.

\subsubsection{O artigo 31}

"O Governo tem, de um lado, grandes rasgos de generosidade, e, aqui, no seio da Comissão de Finanças, tudo se faz, contando que seja negada ajuda aos Estados que não estão sintonizando com a política federal"

(Coelho Rodrigues, DCD, 25/06/1949, pp. D013940301.TIF).

Conforme já foi adiantado no parecer de Unírio Machado ao projeto 2.055, de 1952, pelo artigo 31 a Constituição Federal de 1946 vedava à União, aos Estados, ao Distrito Federal e aos Municípios o direito de criar distinções entre brasileiros ou preferências em favor de uns contra os outros.

Dessa forma, mais uma vez parlamentares conseguiram justificar, em termos federativos, proposições que não tratavam de questões federativas em si. Esta foi a estratégia, por exemplo, adotada por Campos Vergal (PSP/SP) na defesa do projeto n ${ }^{\circ} 2115-\mathrm{D}$, de 1952, que concedia auxílio de Cr\$ 5.000.000,00 ao Município de Santo André para as comemorações do $4^{\circ}$ Centenário de sua fundação e de Cr\$ 500.000,00 à Prefeitura Municipal de Jaú, também para as comemorações de seu centenário, durante o encaminhamento da votação da matéria. A sua alegação era de que a Casa estaria votando favoravelmente pela Comissão de Finanças (CF), em prol de auxílios a festas comemorativas das capitais de

\footnotetext{
${ }^{71}$ Apesar da lenta tramitação, a proposta de criação da Universidade de Belém foi transformado na lei n. ${ }^{0} 3191$, de 1957 (Cf. Dofc, 02/07/1957). Mesma sorte não teve a proposição n. ${ }^{\circ} 2.055$, de 1952, que foi arquivada em 1956, a despeito do esforço da CCJ aludido acima.
} 
Estados do país, ao passo que rejeitava, quase sistematicamente, auxílio idêntico a cidades do interior $^{72}$.

Entretanto, é o discurso de Coelho Rodrigues (UDN/PI) que talvez melhor sintetize o emprego desta tática durante a avaliação do mérito da proposição $\mathrm{n}^{\circ}$ 810-B, que dispunha sobre empréstimos aos Estados. A seu ver, ao negar às unidades da federação pequeno auxílio para as suas dificuldades financeiras, o parecer emitido pela $\mathrm{CF}$ atestava, novamente, a diversidade com que o governo federal tratava as unidades subnacionais. Daí o seu inconformismo, que é justamente sintetizado na epígrafe que abre esta seção: “O Governo tem, de um lado, grandes rasgos de generosidade, e, aqui, no seio da Comissão de Finanças, tudo se faz, contando que seja negada ajuda aos Estados que não estão sintonizando com a política federal" (DCD, 25/06/1949, pp. D013940301.TIF) ${ }^{73}$.

De fato, a CF foi favorável à abertura de crédito para intensificar o combate à broca de café, o que acaba, na prática, beneficiando os estados do sudeste, a região mais rica da federação ${ }^{74}$. Na contramão, a mesma comissão e mostrou contrária à emenda proposta por Plínio Lemos (UDN/PB) ao projeto n 914-A/1947, que autorizava o Poder Executivo a abrir ao Ministério da Viação e Obras Públicas o crédito de Cr\$10.000.000,00 como contribuição para o desenvolvimento econômico do Maranhão.

Na emenda, Lemos pedia a separação de igual verba ao estado da Paraíba, ao passo que o deputado Adelmar Rocha (UDN/PI) fazia a mesma solicitação em benefício do Piauí. A CF opinou, porém, no sentido da referida emenda ser remetida para constituir projeto à parte, votando a favor da manutenção do texto original da proposição. Insatisfeito, Lemos é taxativo:

\footnotetext{
${ }^{72}$ Assim protestava o representante do PSP: "Não posso entender essa dupla maneira de encarar o problema mais social do que histórico, se as capitais fazem jus a auxílios enormes, inclusive a Capital do meu Estado, por que cidades do interior como Santo André, Jaú, Leopoldina, Teófilo Otoni também não gozam dessas regalias de direitos?" (Cf. DCD, 13/11/1953, p. D013320670.TIF).

${ }^{73} \mathrm{O}$ deputado ainda destaca o tratamento diverso que o governo federal daria a empresas ricas, que receberiam doações da União, ajuda negada a companhias menores que incorriam em dificuldades financeiras.

${ }^{74}$ Vide debate sobre o projeto $\mathrm{n}^{\circ}$ 834-A/1947 reproduzido no DCD, 06/01/1948, p. D014080162.TIF.
} 
Entendo que não há razão alguma para justificar a preferência da Comissão de Finanças. O Maranhão é muito mais rico e poderoso do que a Paraíba. Além disso, porém, importa o poder considerar o poder político que fala muito mais alto nesta Casa e deveria orientar a Comissão de Finanças, no sentido de proceder com justiça, atendendo às necessidades das populações das demais unidades federativas"

(DCD, 15/01/1948, pp. D014080414.TIF-D014080415.TIF, grifo meu).

Deste modo, até mesmo políticas explicitamente paroquialistas eram respaldadas nos termos do art. 31, a partir da interpretação que os parlamentares teciam do preceito constitucional sobre a indistinção entre os entes federados. Na prática, se pedia um tratamento diferenciado para determinadas unidades subnacionais - concessão de benefícios - pela própria inconstitucionalidade de proposições que distinguissem os entes federados entre si. Era no esteio de um projeto que beneficiasse um estado, ou alguns estados, que se apresentavam emendas solicitando a extensão do auxílio a outros governos subnacionais, justamente argumentando a inadequação da matéria em sua versão original, que não considerava os demais membros da federação.

Como Santos (2003) pondera, todavia, a reiterada crítica de que os parlamentares do período 1945-1964 não possuíam visão nacional, transformando-se em meros porta-vozes de interesses particularistas estaduais, não leva em consideração que esta foi precisamente a única forma de fazer valer uma pálida sombra de federalismo, naquilo que federalismo significa de respeito às vontades das unidades que compõem a Federação (SANTOS, p. 56). Logo, não deve causar estranhamento o recurso às justificativas de cunho federativo para matérias locais, mas não propriamente federativas. A disputa pelos repasses da União era intensa, sobretudo pela situação de dependência política e econômica dos governos subnacionais ante o poder central.

Isto não equivale a afirmar, porém, que as questões paroquiais representavam obstáculo à governabilidade durante a democracia populista. 


\subsubsection{As votações efetivas de medidas paroquiais}

A despeito da ferrenha concorrência dos legisladores ao tempo das discussões de políticas regionais, a disputa por repasses federais não constituía uma das tônicas do dia-a-dia da Câmara. Muito embora 155 das 686 matérias encaminhadas à verificação de votação ao longo de todo o período tratassem de questões locais, muitas das quais alheias às competências da União e dos estados - como subvenções a programas sociais e concessões de auxílios a eventos e festividades municipais diversas, para citar algumas -, a Casa parecia se resolver mais rapidamente nestas situações, prevalecendo a manutenção de reiterados conflitos em debates de outra monta ${ }^{75}$.

Analisando o conteúdo das proposições objeto de checagem de resultado durante a República de 1946 a partir de sua generalidade, efeitos e impacto territorial, critérios classificatórios empregados por Ricci $(2003)^{76}$, até se observa certa freqüência de propostas políticas de efeito circunscrito. Entretanto, essas matérias finalizadas a atender demandas locais e/ou regionais rendiam mais debates calorosos nas deliberações registradas nos anais da Casa do que emperravam, de fato, a pauta de votação.

Os representantes não poupariam críticas à conduta da Comissão de Constituição e Justiça (CCJ) da Câmara, que se mostraria discricionária no exame de questões regionalistas ao administrar diferentes interpretações sobre o artigo 67, parágrafo $2 .^{\circ}$ da Carta de 1946 , referência obrigatória para a qualificação da constitucionalidade de matérias em trâmite na Câmara Federal visando destinar investimentos da União a determinadas localidades. Tampouco seriam economizadas censuras ao desleixo do governo, alheio ao devido

\footnotetext{
${ }^{75}$ Essa soma desconsidera 63 questões cujo teor não pode ser classificado a partir da análise de suas respectivas ementas, justificativas, ou mesmo pelas discussões ocorridas durante a apreciação dos referidos textos pelo plenário.

${ }^{76}$ Em seu exame da produção legislativa brasileira, o autor justifica sua opção em categorizar as normas segundo a ponderação desses três parâmetros. A seu ver, "o primeiro critério classifica as leis em função da dimensão do impacto previsto sobre os sujeitos (ou coisas) diretamente afetados. O segundo, em função dos tipos de efeitos previstos sobre as partes interessadas pela lei. O terceiro, por sua vez, ressalta a dimensão física do impacto previsto" (Ricci, 2003, p. 706).
} 
cumprimento da letra da lei. Contudo, a aparente divisão operada no parlamento em termos de oratória se faria de menor magnitude na fase definitiva de posicionamento - a decisão a votos no plenário. É o que sinalizam os dados inscritos na tabela 3.12:

Tabela 3.12 - Verificações de votação concedidas segundo o teor das medidas em exame, por coalizão (1946-1964)*

\begin{tabular}{|l|c|c|c|c|}
\hline \multirow{3}{*}{ Coalizão } & \multicolumn{2}{|c|}{$\begin{array}{c}\text { Te or das maté rias de ve rificação } \\
\text { de votação concedida** }\end{array}$} & \multirow{2}{*}{ Total } \\
\cline { 2 - 4 } & Local & Ge ral & $\begin{array}{c}\text { Sem } \\
\text { Informação*** }\end{array}$ & \\
\hline \hline Dutra II & 49 & 201 & 22 & 272 \\
\hline Dutra III & 8 & 25 & 3 & 36 \\
\hline Vargas I & 21 & 92 & 8 & 121 \\
\hline Vargas II & 10 & 126 & 16 & 152 \\
\hline Vargas III & - & 10 & 1 & 11 \\
\hline Café Filho I & 6 & 94 & 2 & 102 \\
\hline Café Filho II & 3 & 55 & - & 58 \\
\hline N. Ramos & 2 & 57 & 3 & 62 \\
\hline JK I & 47 & 440 & 31 & 518 \\
\hline JK II & 71 & 168 & 8 & 247 \\
\hline Quadros & 6 & 31 & - & 37 \\
\hline R. Mazzili & 1 & 3 & - & 4 \\
\hline Goulart I & - & 4 & - & 4 \\
\hline Goulart II & 9 & 53 & 3 & 65 \\
\hline Goulart III & 1 & 4 & 1 & 6 \\
\hline Goulart IV & 1 & 3 & - & 4 \\
\hline Goulart V & - & 7 & - & 7 \\
\hline Goulart VI & 6 & 16 & - & 22 \\
\hline Goulart VII & - & 1 & - & 1729 \\
\hline Total & 241 & 1390 & 98 & $(5,7 \%)$ \\
\hline \\
\hline
\end{tabular}

* Considera todas as vezes nas quais uma mesma matéria foi objeto de verificação de votação. **Adota os mesmos critérios de classificação apresentados em Ricci (2003).

***Sem Informação - Diz respeito às matérias cujo teor não foi possível de ser classificado a partir das ementas em análise e das discussões em plenário.

Fonte: Banco de Dados Legis lativos, Cebrap.

Na apuração das questões locais, dificilmente a Mesa se mobilizaria para evitar que a checagem do resultado, uma vez deferida, redundasse em chamada nominal - percurso mais recorrente nas verificações do gênero (tabela 3.13) -, talvez mesmo porque tendesse a colocar a votos tais matérias quando não seria possível se atingir número legal. 
Tabela 3.13 - Resultado das verificações de votação em proposições de políticas paroquialistas (1946-1964)*

\begin{tabular}{|c|c|c|c|c|c|}
\hline \multirow[b]{2}{*}{ Coalizão } & \multicolumn{4}{|c|}{ Saldo das verificações de quorum em ques tões locais } & \multirow[b]{2}{*}{ Total } \\
\hline & $\begin{array}{c}\text { Decididas por } \\
\text { existência de } \\
\text { quorum }\end{array}$ & $\begin{array}{c}\text { Sem quorum, foram } \\
\text { adiadas por decisão } \\
\text { do presidente }\end{array}$ & $\mid \begin{array}{c}\text { Sem quorum, } \\
\text { seguiram à } \\
\text { votação nominal }\end{array}$ & Outros* & \\
\hline Dutra II & 13 & 9 & 26 & 1 & 49 \\
\hline Dutra III & - & - & 8 & - & 8 \\
\hline Vargas I & - & - & 21 & - & 21 \\
\hline Vargas II & 1 & - & 9 & - & 10 \\
\hline Café Filho I & - & - & - & 6 & 6 \\
\hline Café Filho II & - & - & 3 & - & 3 \\
\hline N. Ramos & - & - & - & 2 & 2 \\
\hline JK I & - & 2 & 33 & 12 & 47 \\
\hline JK II & 1 & 6 & 56 & 8 & 71 \\
\hline Quadros & 1 & 1 & 3 & 1 & 6 \\
\hline R. Mazzili & - & - & 1 & - & 1 \\
\hline Goulart II & - & 2 & 5 & 2 & 9 \\
\hline Goulart III & - & 1 & - & - & 1 \\
\hline Goulart IV & - & - & - & 1 & 1 \\
\hline Goulart VI & - & - & 4 & 2 & 6 \\
\hline Total & $\begin{array}{c}16 \\
(6,6 \%)\end{array}$ & $\begin{array}{c}21 \\
(8,7 \%)\end{array}$ & $\begin{array}{c}169 \\
(70,1 \%)\end{array}$ & $\begin{array}{c}35 \\
(14,5 \%)\end{array}$ & 241 \\
\hline
\end{tabular}

*Desconsidera as coalizões Goulart I, Ve VII e Vargas III, por constituirem cédulas vazias. **Outros - Abarca casos em que se realizou votação nominal diretamente, sem justificativa, ou sob legação da visível falta de número no plenário.

Fonte: Banco de Dados Legis lativos, Cebrap.

De fato, mais da metade das votações nominais decorrentes de verificação de quorum não se mostrariam capazes de validar qualquer decisão do plenário, pela inexistência de manifestações suficientes. O padrão encontrado no capítulo 2, portanto, se confirma, inclusive em termos de posicionamento ideológico do plenário, medido a partir da replicação dos testes referentes à posição majoritária do partido do presidente nas decisões em andamento na Câmara.

Seguindo a tônica do período, a tendência seria o êxito do governo também nas decisões de proposições locais, 
Tabela 3.14 - Vitórias e derrotas do governo em medidas locais*

\begin{tabular}{|c|c|c|c|c|c|}
\hline \multirow{2}{*}{ Coalizão } & \multicolumn{2}{|c|}{ Vitórias } & \multicolumn{2}{|c|}{ Derrotas } & \multirow{2}{*}{ Total } \\
\hline & $\mathbf{N}$ & $\%$ & $\mathbf{N}$ & $\%$ & \\
\hline Vargas I & 2 & 66,7 & 1 & 33,3 & 3 \\
\hline Vargas II & 5 & - & - & - & 5 \\
\hline Café Filho I & 2 & 66,7 & 1 & 33,3 & 3 \\
\hline JK I & 3 & 50,0 & 3 & 50,0 & 6 \\
\hline JK II & 4 & - & - & - & 4 \\
\hline Goulart II & 3 & - & - & - & 3 \\
\hline Total & 19 & 79,2 & 5 & 20,8 & 24 \\
\hline
\end{tabular}

sendo as pequenas variações nitidamente produto do conflito entre governo e oposição do que resultado imediato do teor das medidas em consideração.

Tabela 3.15 - Tipos de vitórias do governo, por coalizão, em medidas locais*

\begin{tabular}{|c|c|c|c|c|c|}
\hline \multirow{3}{*}{ Coalizão } & \multicolumn{4}{|c|}{ Tipo de vitória } & \multirow{3}{*}{ Total } \\
\hline & \multicolumn{2}{|c|}{$\begin{array}{c}\text { Apenas com os } \\
\text { membros da coalizão }\end{array}$} & \multicolumn{2}{|c|}{$\begin{array}{l}\text { Com a ajuda da } \\
\text { oposição }\end{array}$} & \\
\hline & $\mathbf{N}$ & $\%$ & $\mathbf{N}$ & $\%$ & \\
\hline Vargas I & 1 & 50,0 & 1 & 50,0 & 2 \\
\hline Vargas II & 1 & 20,0 & 4 & 80,0 & 5 \\
\hline Café Filho I & 1 & 50,0 & 1 & 50,0 & 2 \\
\hline JK I & 3 & 100,0 & - & - & 3 \\
\hline JK II & 4 & 100,0 & - & - & 4 \\
\hline Goulart II & - & - & 3 & 100,0 & 3 \\
\hline Total & 10 & 52,6 & 9 & 47,4 & 19 \\
\hline \multicolumn{6}{|c|}{ *Considera apenas votações válidas e não-unânimes } \\
\hline \multicolumn{6}{|c|}{ Fonte: Banco de Dados Legislativos, Cebrap. } \\
\hline
\end{tabular}

Em tela de juízo, a governabilidade não se via constantemente comprometida como tanto se apregoa. Em geral, o sistema partidário de 46-64 não parece ter "saído do eixo", tendo as legendas se posicionado na arena legislativa de acordo com as orientações políticas que formalizavam perante o governo e a sociedade. O panorama delineado a partir de toda a investigação empírica precedente afiança, antes, a contestação da visão usual tecida pelos analistas sobre a democracia populista. Definitivamente, a conduta das legendas na Câmara 
não era tão incongruente conforme a literatura amplamente defende. Muito embora inexistisse o estatuto da fidelidade partidária, as especificidades do processo decisório no pré-64 facultavam aos atores contornar as querelas intrapartidárias em prol dos resultados políticos visados. Decerto, os moldes da verificação de votação no período possibilitavam aos legisladores a redução do efeito-informação, facilitando a superação da relatada dificuldade de se compor maiorias capazes de salvaguardar interesses diversos em plenário. 


\section{Conclusão}

Compreender a influência concreta do facciosismo intrapartidário sob os resultados políticos substantivos alcançados pelo governo na Câmara dos Deputados entre 1946 e 1964 foi o objetivo norteador deste trabalho, que se insere no debate desenvolvido por respeitados especialistas dedicados ao exame do período, especialmente preocupados com a capacidade decisória própria das gestões presidenciais sucedidas ao longo de toda a democracia populista (FIGUEIREDO, LIMONGI, 1998; AMORIM NETO, SANTOS, 2001; SANTOS, F., 2002; SANTOS, 2003). Muito embora a literatura e os registros históricos apontem a prevalência de fortes cisões no seio das principais legendas da época, além de já serem conhecidos os baixos índices de coesão encerrados pelos partidos naquela experiência, o peso efetivo das divisões internas que abalariam a unidade da coalizão de apoio ao Executivo no parlamento permanecia uma incógnita.

O exame da fase final do processo decisório - as votações em plenário - revelou que apenas eventualmente a base governista não pôde assegurar, sozinha, a passagem da própria agenda de trabalho, em função de rachas internos. Somente nas gestões de Getúlio e Juscelino as contribuições de deputados de oposição se fizeram capitais para a aprovação dos programas do governo. Ainda assim, seriam as metas varguistas as mais dependentes deste subsídio externo. Grande parte das medidas desenvolvimentistas de JK gozaria do endosso suficiente da própria base parlamentar para se fazer acolhida no Legislativo.

Definitivamente, o facciosismo intrapartidário, da forma como é normalmente discutido quando se trata da República de 46, não comprometeu, no geral, a linha administrativa dos presidentes eleitos à época. Num contexto de contínuas querelas entre deputados reunidos sob uma mesma filiação política, a ameaça da infidelidade partidária, alheia a qualquer regulação legal, foi contornada através do emprego tático de mecanismos procedimentais no decurso das deliberações. 
Com efeito, as informações reunidas nesta investigação mostram que a situação contava com dispositivos regimentais para testar a sua força relativa no andamento das decisões que tinham lugar na Câmara. Através da verificação de quorum, era possível minimizar as chances de insucesso, uma vez encontrada uma fórmula para se abrandar a dificuldade do governo em estimar com precisão o real tamanho da sua base parlamentar entrave denominado de efeito-informação por Riker (1962). Isto porque a direção dos trabalhos legislativos na Casa esteve praticamente sempre entregue aos pessedistas, que estiveram fora da coalizão presidencial apenas no breve episódio de Jânio Quadros à frente do país, podendo manipular o andamento das votações por todo o período restante. Afinal, o rumo das deliberações ficava à mercê da ação do coordenador da Mesa Diretora, autorizado a agir discricionariamente, conforme a letra do Regimento Interno então seguido, tão logo se observasse a inexistência de número legal ao final da checagem dos votos.

Dificilmente a contagem das preferências individuais redundaria em definição das matérias com saldos questionados, recolocadas à apreciação dos legisladores. Como vimos, a maioria das verificações de quorum redundava em placares inválidos, cabendo ao presidente da sessão estabelecer o próximo passo. Mesmo supondo, porém, que a sua inclinação natural não fosse escolher o melhor caminho decisório a ser perseguido em prol do êxito das intenções governistas - opção teoricamente muito duvidosa -, a situação no poder tinha a seu favor tanto os resultados reveladores da divisão entre os seus como o caráter coercitivo das checagens das votações simbólicas, quase idêntico ao encerrado pelas decisões nominais. Na prática, a contagem dos votos individuais nas conferências de número legal, comunicados em voz alta pelo primeiro secretário da Mesa, expunha os representantes presentes da mesma forma que o faziam as chamadas nominais, elevando o custo político para aqueles que desejavam se manifestar contrariamente ao esperado pela maioria. A única diferença entre os dois processos consistia na publicação da lista elaborada na segunda opção, que era 
disponibilizada nos Diários da Câmara dos Deputados, de acesso público. Em termos de supressão do anonimato no espaço circunscrito ao Legislativo, portanto, a correspondência de ambos os mecanismos deliberativos é indubitável.

A meu ver, não há motivo para se subestimar a relevância dos escores obtidos na verificação de votação enquanto atenuante do efeito de Riker no plenário. O uso estratégico deste dispositivo regimental facultou tanto ao governo como à oposição uma melhor visualização das suas forças relativas na distribuição das preferências durante as deliberações em pauta. Reagrupamentos e até mesmo reconfigurações das composições observadas na Câmara podiam ser acertados segundo a confrontação entre o resultado que se anunciava e o saldo realmente desejado. Antecipações frente à leitura da Mesa sobre as mesmas ponderações também se fariam analisadas nos cálculos realizados por ambas as frentes parlamentares, numa interação que teria não apenas garantido o sucesso da passagem da agenda governamental do período, mesmo quando houve contestação em plenário, mas ainda levado parte dos membros da oposição a contribuir com a passagem da agenda dos governos no pré-64, quando assim se fez imperativo.

Não se trata de refutar a existência do facciosismo em 46-64. A questão é relativizar a sua essência. As cisões partidárias até podiam ser explícitas ao nível da tribuna, com claras diferenças nos pronunciamentos de grupos parlamentares reunidos sob a mesma legenda, quando dos debates dedicados à agenda do Executivo. No entanto, as divisões se esfacelavam ao tempo das votações efetivas. É este divórcio entre discurso e ação que teria permitido as coalizões governamentais terem dado o suporte necessário às administrações vigentes à democracia populista. 


\section{REFERÊNCIAS}

ABRANCHES, Sérgio Henrique. "Presidencialismo de coalizão: o dilema institucional brasileiro." Dados: Revista de Ciências Sociais 31 (1) (1988): 5-34.

AMES, Barry. The Deadlock of Democracy in Brazil. Michigan: University of Michigan Press, 2001.

AMORIM NETO, Octavio \&. SANTOS, Fabiano. “A Conexão Presidencial: Facções Pró e Antigoverno e Disciplina Partidária no Brasil.” Dados: Revista de Ciências Sociais 44 (2) (2001): 291-321.

ARINOS DE MELO FRANCO, Afonso. "Os partidos políticos nacionais - Publicação nacional de doutrina, jurisprudência e legislação.” Revista Forense Jan./Fev. de 1955: Volume 157 (619).

ARRECTHE, Marta. "Continuidades e Descontinuidades da Federação Brasileira: de como 1988 facilitou 1995.” Dados 52(2) (2009): 377-423.

BEIGUELMAN, Paula. "O processo político-partidário brasileiro de 1945 ao plebiscito." MOTA, Carlos Guilherme (Org.). Brasil em perspectiva. Sâo Paulo: Difel, 1969. 319-338.

BELLONI, Frank. P \& BELLER, Dennis C. Faction Politics: Political Parties and Factionalism in Comparative Perspectives. Santa Barbara, CA: ABC-Clio Inc., 1978.

BENEVIDES, Maria Victoria de Mesquita. A UDN e o udenismo - Ambiguidades do liberalismo brasileiro (1945-1965). São Paulo: Paz e Terra, 1981a.

—. O governo Jânio Quadros. Sâo Paulo: Brasiliense, 1981 b.

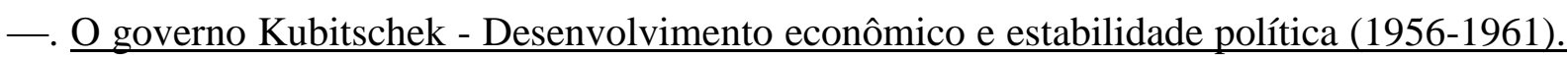
Rio de Janeiro: Paz e Terra, 1979.

BOUCEK, Françoise. "Rethinking factionalism Typologies, Intra-Party Dynamics and Three Faces of Factionalism.” Party Politics 15 (4) (2009): 1-31. 
CAMARGO, Aspásia Alcântara de. "Brésil Nord-Est: Mouvements Paysans et Crise Populiste.” Paris: Tese de Doutorado, 1973.

CAMARGO, Aspásia de Alcântara. "A questão agrária: crise de poder e reformas de base (1930-1964).” FAUSTO, Boris. O Brasil republicano. São Paulo: Difel, 1981. Tomo III, v. 3. CARDOSO, Fernando Henrique. "Partidos e Deputados em São Paulo, o voto e a representação política." LAMOUNIER, Bolívar \& CARDOSO, Fernando Henrique. Os Partidos e as Eleições no Brasi. Paz e Terra, 1978.

CARVALHO, Maria Izabel Valladão. “A Colaboração do Legislativo para o Desempenho do Executivo durante o Governo JK.” Tese de Mestrado. Rio de Janeiro: IUPERJ, 1977.

—. "Mecanismo Conflitual de Decisão na Câmara dos Deputados: O Significado Político da Votação Nominal no Período 1956-1960. Dados Preliminares.” Dados 11 (1973): 194-205.

CARVALHO, Orlando. Ensaios de sociologia eleitoral. Vols. I - Estudos sociais e políticos. Universidade de Minas Gerais, 1958.

DABAT, Christine Rufino. Moradores de Engenho: relações de trabalho e condições de vida dos trabalhadores rurais na zona canavieira de Pernambuco segundo a literatura, a academia e os próprios atores sociais. Recife: Ed.Universitária da UFPE, 2007.

D'ARAUJO, Maria Celina Soares. O segundo governo Vargas (1951-1954). São Paulo: Editora Ática, 1992.

DUVERGER, Maurice. Os partidos políticos. Rio de Janeiro: Zahar Editores, 1980.

FERNANDES, Florestan. "Crescimento econômico e instabilidade política no Brasil."

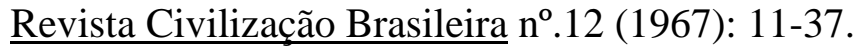

FIGUEIREDO, Argelina Cheibub \& LIMONGI, Fernando. Executivo e Legislativo na Formulação e Execução do Orçamento Federal. São Paulo: Trabalho apresentado em encontro anual da Associação Brasileira de Ciência Política - ABCP, 2000.

—. “Incentivos Eleitorais, Partidos e Política Orçamentária.” Dados 45 (2) (2002): 303-344. 
—. "Relação Executivo-Legislativo no presidencialismo multipartidário: os regimes de 46 e 88.” Trabalho apresentado no XXII Encontro Anual da Anpocs. Caxambu, 1998.

FIGUEIREDO, Argelina Cheibub. "Government Coalitions in Brazilian Democracy." Brazilian Political Science Review 1 (2) (2008): 182-216.

FONTES, Lourival \& CARNEIRO, Glauco. A face final de Vargas. Rio de Janeiro: O Cruzeiro, 1966.

Gláucio, SOARES. Sociedade e Política no Brasil. São Paulo: Difel, 1973.

GOMES, Abgela de Castro \& D'ARAUJO, Maria Celina. Getulismo e Trabalhismo. São Paulo: Editora Ática, 1989.

HIPPOLITO, Lúcia. De raposas e de reformistas - o PSD e a experiência democrática brasileira (1945-64). Rio de Janeiro: Paz e Terra, 1985.

HUCKFELDT, Robert e John SPRAGUE. Citizens, Politics and Social Communication: Information and Influence in an Election Campaign. New York: Cambridge University Press, 1995.

HUNTINGTON, Samuel. El orden político en las sociedades en cambio. Buenos Aires: Paidos, 1972.

INACIO, Magna. “As oposições no presidencialismo de coalizão brasileiro.” Trabalho apresentado no $30^{\circ}$ Encontro Anual da Anpocs. Caxambu, 2006.

JAGUARIBE, Hélio. “As eleições de 62.” Revista Tempo Brasileiro I (2) (1962): 9-30.

KING, David C \& ZECKHAUSER, Richard J. Congressional Vote Options. Harvard University, 2001.

LAFER, Celso. JK e o programa de metas (1956-1961) - Processo de planejamento e sistema político no Brasil. Rio de Janeiro: Editora FGV, 2002.

—. "The planning process and the political system in Brazil: a study of Kubitschek's target plan, 1956-1961.” Tese de doutorado. New York: Cornell University, 1970. 
LEAL, Victor Nunes. Coronelismo, Enxada e Voto - o Município e o Regime Representativo no Brasil . São Paulo: Editora Alfa-Ômega, 1975 [1949].

LEONI, Eduardo. "Ideologia, Democracia e Comportamento Parlamentar: a Câmara dos Deputados (1991-1998).” Dados 45(3) (2002): 361-386.

LIMONGI, Fernando \& FIGUEIREDO, Argelina Cheibub. "Legislativo Brasileiro em Perspectiva Comparada.” INÁCIO, Magna e RENNÓ, Lúcio (Org.). Poder de Agenda e Políticas Substantivas. Belo Horizonte: Editora UFMG, 2009. 77-104.

LIMONGI, Fernando \& FIGUEIREDO, Argelina. "Partidos Políticos na Câmara dos Deputados: 1989-1994.” Dados 38 (3) (1995): 497-525.

Mayhew, D.R. Divided we Govern. Party Control, Lawmaking, and Investigations, 19462002. New Haven-London: Yale University Press, 1991.

MONIZ, Bandeira. O Governo João Goulart: As lutas sociais no Brasil (1961-1964). Rio de Janeiro: Civilização Brasileira, 1983.

NICOLAU, Jairo Marconi. "Disciplina Partidária e Base Parlamentar na Câmara dos Deputados no Primeiro Governo Fernando Henrique Cardoso (1995-1998).” Caxambu, 21 de Outubro de 1999.

OLIVEIRA, Lúcia Lippi de. "Notas sobre o estudo do Partido Social Democrático.” Dados: $\underline{\text { Revista de Ciências Sociais }} 10$ (1973).

PEREIRA, Carlos \& MUELLER, Bernardo. "Comportamento Estratégico em Presidencialismo de Coalizão: As Relações entre Executivo e Legislativo na Elaboração do Orçamento Brasileiro.” DADOS - Revista de Ciências Sociais 45 (2) (2002): 265-301.

PETERSEN, Phyllis Jane. "Brazilian Political Parties: Formarion, Organization, and Leadership, 1945-1959.” Tese de doutorado. Michigan: University of Michigan, 1962.

POOLE, Keith T. \& ROSENTHAL, Howard. "A Spatial Model for Legislative Roll Call Analysis.” American Journal of Political Science 29 (2) (1985). 
POOLE, Keith T. Spatial Models of Parliamentary Voting. New York: Cambridge University Press, 2005.

RICCI, Paolo. “O Conteúdo da Produção Legislativa Brasileira: leis nacionais ou políticas paroquiais?” Dados 46 n.4 (2003): 699-734.

—. "The Content of Law - Concepts and Measures in Legislatives Studies." Working Papers (Political Concepts) 43 (2010): p. 1-27.

RICE, Stuart. "The behaviour of legislative groups: a method of measurement." 1925: p. 6072.

RIKER, William H. The Theory of Political Coalitions. New Haven: Yale University Press, 1962.

SAIEGH, Sebastian M. Ruling by Statute: How Uncertainty and Vote-Buying Shape Lawmaking. New York: Cambridge University Press, 2011.

SAMPAIO, Regina. Adhemar de Barros e o PSP. São Paulo: Global Editora, 1982.

SANTOS, Fabiano. O Poder Legislativo no Presidencialismo de Coalizão. Belo Horizonte: Editora UFMG, 2003.

—. "Partidos e comissões no presidencialismo de coalizão." Dados: Revista de Ciências Sociais 45 (2) (2002): 237-264.

—. "Patronagem e Poder de Agenda na Política Brasileira." Dados: Revista de Ciências Sociais 40 (3) (1997): 465-492.

SANTOS, Wanderley Guilherme dos. "Coalizões parlamentares e instabilidade governamental: a experiência brasileira - 1961/1964." Revista de Administração de Empresas Out/Dez de 1973.

- O Cálculo do Conflito - Estabilidade e crise na política brasileira. Belo Horizonte: UFMG, 2003. 
—. "Paralisia da decisão e comportamento legislativo: a experiência brasileira, 1959-1966."

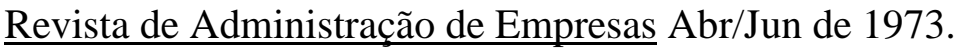

SARTORI, Giovanni. Partidos e Sistemas Partidários. Brasília: Zahar/UNB, 1983.

SCHICKLER, Eric. Disjointed Pluralism: Institutional Innovation and the Development of the U.S. Congress. Princeton: Princeton University Press, 2001.

Schwartzman, Simon. "Veinte años de democracia representativa en Brasil, 1945-1964." Revista Latinoamericana de Ciéncia Política Vol. II, n. 1 (1971): 24-46.

SKIDMORE, Thomas. Brasil: de Getúlio a Castelo. Rio de Janeiro: Paz e Terra, 1975.

SOARES, Gláucio. Sociedade e Política no Brasil. São Paulo: Difel, 1973.

SOUZA, Maria do Carmo Campello de. Estado e Partidos Políticos no Brasil. São Paulo: Editora Alfa-Ômega, 1976.

SOUZA, Maria do Carmo Campelo de. "Federalismo no Brasil: aspectos políticosinstitucionais (1930-1964).” 21 (61) (2006).

—. "Federalismo no Brasil: aspectos políticos-institucionais (1930-1964)." (2006).

STEPAN, Alfred. "Para uma nova análise comparativa do federalismo e da democracia: Federações que restringem ou ampliam o poder do demos.” Dados 42(2) (1999): 197-252.

TAAGEPERA, Rein \& SHUGART, Matthew Soberg. Seats and Votes: The Effects and Determinants of Electoral Systems. New Haven, CT and London: Yale University Press, 1989.

VERGE, Tània e GOMEZ, Raúl. "Factionalism in multi-level contexts: When party organisation becomes a device.” Party Politics Março de 2011: 1-19. 


\section{Anexos}

\begin{tabular}{|c|c|c|c|c|c|c|c|c|}
\hline \multicolumn{9}{|c|}{ ANEXO A - Coalizões (1946-1964)* } \\
\hline \multirow{2}{*}{ Presidente } & \multirow{2}{*}{\begin{tabular}{|c|} 
Partido \\
do \\
Presidente \\
\end{tabular}} & \multirow{2}{*}{ Partidos na Coalizão } & \multirow{2}{*}{ Legislatura } & \multicolumn{2}{|c|}{ Data da Coalizão } & \multirow{2}{*}{ Evento } & \multicolumn{2}{|c|}{ Duração } \\
\hline & & & & Início & Fim & & Dias & Mese: \\
\hline Dutra I & PSD & PSD-PTB & 1946 & $31 / 01 / 1946$ & $13 / 10 / 1946$ & Eleições Legislativa e Presidencial & 253 & 8 \\
\hline Dutra II & PSD & PSD-PR-UDN & 1946 & $14 / 10 / 1946$ & $30 / 03 / 1950$ & Sai PTB, entra UDN-PR & 1246 & 42 \\
\hline Dutra III & PSD & PSD-UDN & 1946 & $01 / 04 / 1950$ & $30 / 01 / 1951$ & Saída do PR & 299 & 10 \\
\hline Vargas I & PTB & PSD-PTB-PSP & 1951 & $01 / 02 / 1951$ & $15 / 06 / 1953$ & Eleições Presidencial e Legislativa & 854 & 28 \\
\hline Vargas II & PTB & PSD-PTB & 1951 & $15 / 06 / 1953$ & $02 / 06 / 1954$ & Saída do PSP & 347 & 12 \\
\hline Vargas III & PTB & PSD-PTB-PSP & 1951 & 03/06/1954 & $24 / 08 / 1954$ & Entrada do PSP & 81 & 3 \\
\hline Café Filho I & PSP & PSD-PR-UDN & 1951 & $25 / 08 / 1954$ & $31 / 01 / 1955$ & Suicídio Vargas & 156 & 5 \\
\hline Café Filho II & PSP & PSD-PR-UDN & 1955 & $01 / 02 / 1955$ & $11 / 11 / 1955$ & Eleição Legislativa & 280 & 9 \\
\hline N. Ramos & PSD & PSD-PTB-PSP-PR & 1955 & $11 / 11 / 1955$ & $31 / 01 / 1956$ & Crise Político-Militar & 80 & 3 \\
\hline JK I & PSD & PSD-PTB-PSP-PR & 1955 & $01 / 02 / 1956$ & $31 / 01 / 1959$ & Eleição Presidencial & 1080 & 36 \\
\hline JK II & PSD & PSD-PTB-PSP-PR & 1959 & $01 / 02 / 1959$ & $31 / 01 / 1961$ & Eleição Legislativa & 720 & 24 \\
\hline Quadros & PTN & UDN-PSP-PR & 1959 & $01 / 02 / 1961$ & $24 / 08 / 1961$ & Eleição Presidencial & 204 & 7 \\
\hline Ranieri Mazzili & S/PART & Interino-Pres. CD & 1959 & $25 / 08 / 1961$ & 07/09/1961 & Crise Político-Militar & 13 & 0 \\
\hline Goulart I (Neves I) & PTB & PSD-PTB-PDC & 1959 & 08/09/1961 & $12 / 10 / 1961$ & Posse Primeiro Ministro & 34 & 1 \\
\hline Goulart II (Neves II) & PTB & PSD-PTB-PDC-PSP & 1959 & $13 / 10 / 1961$ & $12 / 07 / 1962$ & Mudança Gabinete & 269 & 9 \\
\hline Goulart III (B. Rocha) & PTB & PSD-PTB-PSB & 1959 & $13 / 07 / 1962$ & $17 / 09 / 1962$ & Mudança Primeiro Ministro & 64 & 2 \\
\hline Goulart IV (H. Lima) & PTB & PSD-PTB-PSB & 1959 & $18 / 09 / 1962$ & $23 / 01 / 1963$ & Mudança Primeiro Ministro & 125 & 4 \\
\hline Goulart V & PTB & PSD-PTB-PSP-PSB & 1963 & $24 / 01 / 1963$ & 07/06/1963 & Assume Pres. Eleição Legislativa & 133 & 4 \\
\hline Goulart VI & PTB & PSD-PTB-PDC & 1963 & $08 / 06 / 1963$ & $19 / 12 / 1963$ & Saída do PSB entrada do PDC & 191 & 6 \\
\hline Goulart VII & PTB & PSD-PTB & 1963 & $20 / 12 / 1963$ & $31 / 03 / 1964$ & Golpe de Estado & 101 & 3 \\
\hline Total do período & & & & & & & 6530 & 216 \\
\hline
\end{tabular}

*Reproduzido de Figueiredo (2008, p. 189). 
ANEXO B - Alterações regimentais no processo de votação

\begin{tabular}{|c|c|c|c|c|c|c|c|c|}
\hline \multirow{2}{*}{ Questões } & \multicolumn{8}{|c|}{ Regimentos e Resoluções } \\
\hline & 1989 & 1964 & 1962 & 1959 & 1955 & 1949 & 1947 & 1934 \\
\hline $\begin{array}{l}\text { Necessidade de apoiamento para a deferência do } \\
\text { pedido de verificação de votação }\end{array}$ & $\mathrm{Sim}^{*}$ & $\operatorname{Sim} * *$ & Omisso & $\operatorname{Sim} * *$ & $\operatorname{Sim} * *$ & Não & Não & Não \\
\hline $\begin{array}{l}\text { Verificação de votação precedida de renovação da } \\
\text { votação simbólica }\end{array}$ & Não & Não & Omisso & Não & Não & Sim & Não & Não \\
\hline $\begin{array}{l}\text { Decurso de uma hora entre uma e outra verificação } \\
\text { de votação }\end{array}$ & $\operatorname{Sim} * * *$ & $\operatorname{Sim}^{* * *}$ & $\operatorname{Sim}^{* * *}$ & Não & Não & Não & Não & Não \\
\hline Restrição de uma verificação por votação & Não & Não & Não & Não & Não & Sim & Sim & Sim \\
\hline $\begin{array}{l}\text { Possibilidade de dispensa da chamada por falta de } \\
\text { número ou pelo adiantado da hora }\end{array}$ & - & Sim & Omisso & Sim & Sim & Sim & Sim & Sim \\
\hline Possibilidade de se declarar em "Abstenção" & Sim & Sim & Sim & Não & Não & Não & Não & Não \\
\hline $\begin{array}{l}\text { Desempate de votações como competência do } \\
\text { Presidente da Câmara }\end{array}$ & Sim & Sim & Omisso & Sim & Sim & Sim & Sim & Omisso \\
\hline $\begin{array}{llll}\begin{array}{l}\text { Votação nominal compulsória para leis } \\
\text { complementares }\end{array} & & \\
\end{array}$ & Sim & - & Sim & Não & Não & Não & Não & Não \\
\hline
\end{tabular}

*Mínimo de 6\% deputados ou líderes que representem esse $n^{\circ}$.

**Mínimo de 20 deputados.

*** Desde que contatado $n^{\circ}$ legal, isto é, quorum para votação, na verificação imediatamente anterior.

Fonte: Câmara dos Deputados. 


\section{ANEXO C - Verificação de votação precedida de renovação da votação simbólica}

Embora seja desconhecida a alegação para se propor a inclusão da possibilidade de se renovar a votação simbólica antes de se proceder à verificação de quorum, é muito provável que a economia de tempo conste no cálculo que deu origem ao incremento regimental validado pela Res. $\mathrm{n}^{\circ}$ 34, de 1949 (art. 135, $\S 3^{\circ}$ ). Afinal, a contagem de votos por fileiras de poltronas no plenário da Câmara dos Deputados se mostrava, à época, quase tão demorada quanto uma chamada nominal. Na ausência de qualquer recurso a automatizar - e, assim, acelerar - o processo, restava ao $1^{\circ}$ Secretário da Mesa o anúncio, em voz alta, do resultado, à medida que se fizesse a verificação de cada fila $\left(\S 4^{\circ}\right)$. A lentidão deste procedimento só não se fazia da mesma ordem observada nas situações em que se passava a lista porque, na checagem de quorum, a deliberação ficava restrita aos limites do recinto, não estando previsto o inconveniente de se tomar o voto dos deputados reunidos em comissões, como se fazia nas votações nominais $^{77}$.

A deliberação de uma emenda ao PL. no 1519-B/1951, que regula a inatividade dos militares, ilustra a possibilidade de renovação da decisão simbólica. Acompanhe:

O SR. PRESIDENTE - Os senhores que aprovam a emenda ${ }^{\circ} 21$, queiram ficar como estão (Pausa).

Rejeitada.

O SR. FELIX VALOIS (Pela ordem) requer verificação de votação.

Feita a nova votação simbólica é dada como Rejeitada.

O SR. FELIX VALOIS (Pela ordem) insiste na verificação da votação, por bancadas.

Procedendo-se à verificação, por bancadas, reconhece-se terem votado a favor 8 Srs.

Deputados e contra 149, total 157, com o senhor Presidente, 158.

O SR. PRESIDENTE - Está rejeitada a emenda.

(Diário da Câmara dos Deputados, 03 de março de 1953, p. D013200013.TIF, col. 4).

Muito possivelmente, a insistência pela verificação de quorum foi a regra, tornando ineficiente a mudança regimental proposta em 1949. Daí a supressão da opção de renovação da votação simbólica ocorrer já a partir da Res. nº 582, de 1955.

\footnotetext{
${ }^{77}$ A Res. $n^{\circ}$ 34, de 1949, era taxativa: Art. 136, $\S 4^{\circ}[\ldots]$ se houver Comissão reunida, proceder-se-á à chamada na Mesa e nas salas das Comissões. A Mesa dará conhecimento prévio às Comissões que estiverem reunidas da matéria cuja votação nominal vai realizar-se.
} 


\section{ANEXO D - Escolhas do presidente sobre o rumo de votações sem quorum}

Pela letra do regimento, o presidente da Mesa Diretora deveria mandar proceder à chamada nominal sempre que uma verificação de quorum revelasse ausência de número, salvo se a julgasse dispensável pelo adiantado da hora ou, mesmo, pelo visível esvaziamento do plenário (Res. $\mathrm{n}^{\circ} 10$, de 1947, art. 129, §4º).

Na passagem reproduzida a seguir, sobre o Projeto de Lei $\mathrm{n}^{\circ}$ 1344-A, de 1948, que regulava o emprego de fibras nacionais na fabricação de fios diversos, o esgotamento da sessão é a justificativa apresentada pelo diretor dos trabalhos na Câmara para interromper o curso natural da votação. Observe:

\section{O SR. PRESIDENTE - [...]}

Vou submeter a votos o projeto.

É dado como rejeitado.

O SR. PEDRO POMAR (Pela ordem) requer verificação da votação.

Procedendo-se à verificação de votação reconhece-se terem votado a favor 21 Srs. Deputados e contra 33; total 54.

O SR. PRESIDENTE - Não há número.

Pelo adiantado da hora deixo de mandar proceder à chamada.

(Diário da Câmara dos Deputados, 12 de maio de 1949, p. D013910333.TIF, col. 4).

A visível falta de número, por sua vez, é o apelo do presidente para adiar a apreciação do Projeto de Lei $n^{\circ}$ 890, de 1947, que promovia a instalação de fábricas de cimento em território nacional através de iniciativas privadas e em colaboração com os Estados. Muito embora, dessa vez, a verificação de quorum esteja bem mais próxima do mínimo legal para que a decisão seja considerada válida, quando comparada ao caso anterior - bastando mais 33 votos para se alcançar os 144 necessários -, opta-se pela suspensão da deliberação:

O SR. PRESIDENTE - Vou submeter a votos o projeto.

O SR. HENRIQUE OEST (Para encaminhar a votação) - Sr. Presidente, este projeto, de minha autoria, visa, principalmente, o incremento da indústria de cimento no Brasil [...]

Em seguida, é dado como rejeitado o projeto.

O SR. HENRIQUE OEST (Pela ordem) requer verificação de votação.

Procedendo-se à verificação de votação, reconhece-se terem votado a favor $14 \mathrm{Srs}$. Deputados e contra, 97, total: 111.

O SR. PRESIDENTE - Não há número.

Sendo visível a falta de número, deixo de mandar proceder à chamada. (Diário da Câmara dos Deputados, 06 de abril de 1948, p. D014080165.TIF, col. 2-3). 
Ainda assim, até aí inexiste qualquer irregularidade. O regimento faculta ao presidente a escolha de avançar a sessão para além do horário de encerramento previsto ou adiar a votação para garantir a finalização dos trabalhos a tempo tanto como o autoriza a decidir entre prosseguir com uma deliberação aparentemente fadada a um resultado inválido ou antecipar sua postergação evitando a passagem da lista nominal num plenário que se vê vazio. Basta agir como lhe parecer mais adequado dentre tais opções.

O acompanhamento das escolhas do presidente revelou, porém, a construção de uma postura alternativa, iniciada a partir de 1954, sem respaldo regimental. Muito pelo contrário: o argumento da "visível falta de número" começa a ser mobilizado para embasar o recurso direto à chamada nominal, apesar de ser originalmente proposto para se defender a dispensa do mesmo método de deliberação. Tal é o esclarecimento apresentado para se omitir a verificação de quorum na votação de um artigo do Projeto de Lei no 1069-C, de 1950, que reorganiza as Secretarias do Ministério Público Federal:

O SR. PRESIDENTE: [...]

Em votação o art. $7^{\circ}$. (Aprovado).

O SR. ARTUR SANTOS:

(Pela ordem) requer verificação da votação.

Feita a nova votação simbólica é dado como aprovado.

O SR. ARTUR SANTOS:

(Pela ordem) insiste na verificação da votação, por bancadas.

O SR. PRESIDENTE:

Sendo visível a falta de número, vai-se proceder à chamada e conseqüente votação nominal.

Os Srs. Deputados que votarem a favor do art. $7^{\circ}$ responderão Sim e os que votarem contra responderão Não.

O SR. RUY SANTOS:

$\left(3^{\circ}\right.$ Secretário, servindo de $\left.1^{\circ}\right)$, procede à chamada nominal.

O SR. PRESIDENTE:

Responderam a chamada nominal e votaram 161 Srs. Deputados, sendo 160 Sim e 1 Não.

Está aprovado o art. $7^{\circ}$.

(Diário da Câmara dos Deputados, 29 outubro de 1954, p. D012700670.TIF, col. 1).

Definitivamente, manipulava-se um dispositivo regimental às avessas, forçando a solução de matérias consideradas relevantes no período - que ultrapassavam $30 \%$ dos casos 
em que o presidente ignorou o "protocolo" e autorizou a chamada sem prévia verificação de quorum. 
ANEXO E -Autoria dos pedidos de verificação concedidos, por coalizão (1946-1964)*

\begin{tabular}{|l|c|c|c|c|c|}
\hline \multirow{2}{*}{ Coalizão } & \multicolumn{4}{c|}{ Autoria } & \multirow{2}{*}{ Total } \\
\cline { 2 - 5 } & Governo & Oposição & $* *$ SI & $* * *$ Avulso & \\
\hline \hline Dutra II & 63 & 207 & 2 & - & 272 \\
\hline Dutra III & 23 & 13 & - & - & 36 \\
\hline Vargas I & 58 & 63 & - & - & 121 \\
\hline Vargas II & 80 & 71 & 1 & - & 152 \\
\hline Vargas III & 2 & 9 & - & - & 11 \\
\hline Café Filho I & 19 & 82 & 1 & - & 102 \\
\hline Café Filho II & 36 & 22 & - & - & 58 \\
\hline N. Ramos & 10 & 51 & 1 & - & 62 \\
\hline JK I & 114 & 395 & 9 & - & 518 \\
\hline JK II & 49 & 195 & 3 & - & 247 \\
\hline Quadros & 16 & 21 & - & - & 37 \\
\hline Ranieri Mazzili & - & - & - & 4 & 4 \\
\hline Goulart I (Neves I) & 2 & 2 & - & - & 4 \\
\hline Goulart II (Neves II) & 22 & 41 & 2 & - & 65 \\
\hline Goulart III (B. Rocha) & 1 & 4 & 1 & - & 6 \\
\hline Goulart IV (H. Lima) & - & 4 & - & - & 4 \\
\hline Goulart V & 4 & 3 & - & - & 7 \\
\hline Goulart VI & 13 & 8 & 1 & - & 22 \\
\hline Goulart VII & - & 1 & - & - & 1 \\
\hline \multicolumn{1}{|c|}{ Total } & 512 & 1192 & 21 & 4 & $\mathbf{1 7 2 9}$ \\
\hline & $(29,6 \%)$ & $(68,9 \%)$ & $(1,2 \%)$ & $(0,2 \%)$ & \\
\hline
\end{tabular}

*Desconsidera votações nomnais asseguradas regimental ou constitucionalmente. **SI: Sem informação - Diz respeito às vezes em que o nome do parlamentar autor do pedido de verificação não aparece nos diários da Câmara. ***Avulso - Categoria exclusiva para o governo de Mazzili, que foi meramente transitório, sem a formação de coalizão parlamentar de apoio ao presidente, não sendo possível posicionar a autoria dos pedidos de verificação de votação concedidos à época.

Fonte: Banco de Dados Legislativos, Cebrap. 
ANEXO F - Distribuição dos pedidos de verificação de votação, por partidos (1946-1964)

\begin{tabular}{|c|c|c|c|c|c|c|c|c|c|c|c|}
\hline Governo & Origem & PCB & PRT & PSB & PSD & PSP & PTB & UDN & Outros & SI & Total \\
\hline \multirow{3}{*}{ Dutra } & "Oposição & $\bar{~} 56$ & - & - & - & 67 & 67 & - & 29 & - & 219 \\
\hline & Coalizão & - & - & - & 26 & - & - & 54 & 7 & - & 87 \\
\hline & $\mathrm{SI}^{*}$ & - & - & - & - & - & - & - & - & 2 & 2 \\
\hline \multirow{3}{*}{ Vargas } & Oposição & - & 20 & 1 & - & 11 & - & 82 & 29 & - & 143 \\
\hline & Coalizão & - & - & - & 51 & 16 & 73 & - & - & - & 140 \\
\hline & SI & - & - & - & - & - & - & - & - & 1 & 1 \\
\hline \multirow{3}{*}{ Café Filho } & Oposição & - & 10 & 2 & - & 15 & 67 & - & 10 & & 104 \\
\hline & Coalizão & - & - & - & 23 & - & - & 29 & 3 & - & 55 \\
\hline & SI & - & - & - & - & - & - & - & - & 1 & 1 \\
\hline \multirow{3}{*}{ Nereu Ramos } & Oposição & - & - & 2 & - & - & - & 48 & 1 & - & 51 \\
\hline & Coalizão & - & - & - & 7 & 3 & - & - & - & - & 10 \\
\hline & SI & - & - & - & - & - & - & - & - & 1 & 1 \\
\hline \multirow{3}{*}{$\mathbf{J K}$} & Oposição & - & - & 64 & - & - & - & 477 & 45 & - & 586 \\
\hline & Coalizão & - & - & - & 44 & 45 & 67 & - & 7 & - & 163 \\
\hline & SI & - & - & - & - & - & - & - & - & 16 & 16 \\
\hline \multirow{3}{*}{ Quadros } & Oposição & - & - & 7 & 1 & - & 11 & - & 2 & - & 21 \\
\hline & Coalizão & - & - & - & - & 2 & - & 5 & 9 & - & 16 \\
\hline & SI & - & - & - & - & - & - & - & - & 0 & 0 \\
\hline Ranieri Mazxilli*** & Avulso & - & - & 2 & & & 1 & 1 & - & - & 4 \\
\hline \multirow{3}{*}{ Goulart } & Oposição & - & - & 17 & - & 1 & - & 25 & 20 & - & 63 \\
\hline & Coalizão & - & - & 1 & 6 & 2 & 26 & - & 7 & - & 42 \\
\hline & SI & - & - & - & - & - & - & - & - & 4 & 4 \\
\hline \multicolumn{2}{|c|}{ Total } & 56 & 30 & 96 & 158 & 162 & 312 & 721 & 169 & 25 & 1729 \\
\hline
\end{tabular}

*SI: Sem informação. ** Inexistem coalizão e oposição formais .

Fonte: Banco de Dados Legis lativos, Cebrap. 
ANEXO G - Autoria dos pedidos de verificação concedidos, por coalizão, segundo a origem das matérias em votação (1946-1964)*

\begin{tabular}{|c|c|c|c|c|c|c|c|c|c|c|c|c|c|c|c|c|c|c|c|c|c|}
\hline \multirow{4}{*}{ Coalizão } & \multicolumn{20}{|c|}{ Origem da matéria em votação } & \multirow{4}{*}{ Total } \\
\hline & \multicolumn{5}{|c|}{ Executivo } & \multicolumn{5}{|c|}{\begin{tabular}{|c|} 
Legislativo \\
\end{tabular}} & \multicolumn{5}{|c|}{\begin{tabular}{|c|} 
Judiciário \\
\end{tabular}} & \multicolumn{5}{|c|}{ Sem Informação } & \\
\hline & \multicolumn{4}{|c|}{ Pedido de verificação } & \multirow{2}{*}{$\mathbf{T}$} & \multicolumn{4}{|c|}{ Pedido de verificação } & \multirow{2}{*}{$\mathbf{T}$} & \multicolumn{4}{|c|}{ Pedido de verificação } & \multirow{2}{*}{$\mathbf{T}$} & \multicolumn{4}{|c|}{ Pedido de verificação } & \multirow{2}{*}{$\mathbf{T}$} & \\
\hline & GOV & OPO & $* * \mathbf{S I}$ & $* * * \mathbf{A}$ & & GOV & OPO & SI & $\mathbf{A}$ & & GOV & OPO & SI & $\mathbf{A}$ & & GOV & OPO & SI & $\mathbf{A}$ & & \\
\hline Dutra II & 4 & 2 & -1 & - & 6 & 58 & 203 & 2 & - & 263 & \begin{tabular}{|l|}
- \\
\end{tabular} & 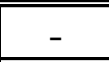 & $\begin{array}{l}- \\
\end{array}$ & $\begin{array}{l}- \\
\end{array}$ & - & 2 & 1 & - & 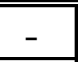 & 3 & 272 \\
\hline Dutra III & 10 & 5 & - & - & 15 & 13 & 8 & - & - & 21 & - & - & - & - & - & - & - & - & - & - & 36 \\
\hline Vargas I & 19 & 28 & - & - & 47 & 39 & 35 & - & - & 74 & - & - & - & - & - & - & - & - & - & - & 121 \\
\hline Vargas II & 17 & 19 & - & - & 36 & 62 & 52 & 1 & - & 115 & - & - & - & - & - & 1 & - & - & - & 1 & 152 \\
\hline Vargas III & - & 1 & - & - & 1 & 2 & 8 & - & - & 10 & - & - & - & - & - & - & - & - & - & - & 11 \\
\hline Café Filho I & 8 & 33 & - & - & 41 & 11 & 48 & 1 & - & 60 & - & 1 & - & - & 1 & - & - & - & - & - & 102 \\
\hline Café Filho II & 2 & 3 & - & - & 5 & 34 & 19 & - & - & 53 & - & - & - & - & - & - & - & - & - & - & 58 \\
\hline N. Ramos & - & 45 & 1 & - & 46 & 10 & 5 & - & - & 15 & - & - & - & - & - & - & 1 & - & - & 1 & 62 \\
\hline JK I & 40 & 147 & 5 & - & 192 & 73 & 243 & 7 & - & 323 & - & - & - & - & - & 1 & 2 & - & - & 3 & 518 \\
\hline JK II & 13 & 64 & 3 & - & 80 & 34 & 118 & 1 & - & 153 & 2 & 4 & - & - & 6 & - & 8 & - & - & 8 & 247 \\
\hline Quadros & 1 & 11 & - & - & 12 & 15 & 10 & - & - & 25 & - & - & - & - & - & - & - & - & - & - & 37 \\
\hline Ranieri Mazzili & - & - & - & 1 & 1 & - & - & - & 1 & 1 & - & - & - & - & - & - & - & - & 2 & 2 & 4 \\
\hline Goulart I & - & - & - & - & - & 2 & 1 & - & - & 3 & - & - & - & - & - & - & 1 & - & - & 1 & 4 \\
\hline Goulart II & 4 & 11 & 1 & - & 16 & 18 & 28 & 1 & - & 47 & - & - & - & - & - & - & 2 & - & - & 2 & 65 \\
\hline Goulart III & - & - & - & - & - & 1 & 4 & 1 & - & 6 & - & - & - & - & - & - & - & - & - & - & 6 \\
\hline Goulart IV & - & - & - & - & - & - & 4 & - & - & 4 & - & - & - & - & - & - & - & - & - & - & 4 \\
\hline Goulart V & 1 & 2 & - & - & 3 & 3 & 1 & - & - & 4 & - & - & - & - & - & - & - & - & - & - & 7 \\
\hline Goulart VI & 1 & 3 & - & - & 4 & 12 & 5 & 1 & - & 18 & - & - & - & - & - & - & - & - & - & - & 22 \\
\hline Goulart VII & - & - & - & - & 0 & - & 1 & - & - & 1 & - & - & - & - & - & - & - & - & - & - & 1 \\
\hline Total & 120 & 374 & 10 & 1 & 505 & 387 & 793 & 15 & 1 & 1196 & 2 & 5 & - & - & 7 & 4 & 15 & - & 2 & 21 & 1729 \\
\hline
\end{tabular}

*Desconsidera votações nomnais asseguradas regimental ou constitucionalmente. **SI: Sem informação. Diz respeito às vezes em que o nome do parlamentar autor do pedido de verificação não aparece nos diários da Câmara. ***A: Avulso. Categoria exclusiva para o governo de Mazzili, que foi meramente transitório, sem a formação de coalizão parlamentar de apoio ao presidente, não sendo possível posicionar a autoria dos pedidos de verificação de votação concedidos à época. 
ANEXO H - Origens das votações nominais, por coalizões (1946-1964)

\begin{tabular}{|l|c|c|c|c|}
\hline \multirow{2}{*}{ Coalizão } & \multicolumn{3}{|c|}{ Origem } & \multirow{2}{*}{ Total } \\
\cline { 2 - 5 } & $\begin{array}{c}\text { Verificações de } \\
\text { votação }\end{array}$ & $\begin{array}{c}\text { Requerimentos } \\
\text { para votação } \\
\text { nominal }\end{array}$ & Outros* & \\
\hline \hline Dutra II & 130 & 5 & - & 135 \\
\hline Dutra III & 36 & 1 & - & 37 \\
\hline Vargas I & 111 & 19 & 8 & 138 \\
\hline Vargas II & 143 & 12 & 3 & 158 \\
\hline Vargas III & 10 & - & 2 & 12 \\
\hline Café Filho I & 94 & 4 & 1 & 99 \\
\hline Café Filho II & 49 & 12 & 3 & 64 \\
\hline N. Ramos & 22 & 6 & - & 28 \\
\hline JK I & 395 & 22 & 5 & 422 \\
\hline JK II & 217 & 1 & 2 & 220 \\
\hline Quadros & 14 & 5 & 4 & 23 \\
\hline R. Mazzili & 2 & 1 & 3 & 6 \\
\hline Goulart I & 3 & - & 2 & 5 \\
\hline Goulart II & 43 & 1 & 4 & 48 \\
\hline Goulart III & 5 & 1 & 1 & 7 \\
\hline Goulart IV & 3 & - & 7 & 10 \\
\hline Goulart V & 6 & - & - & 6 \\
\hline Goulart VI & 21 & 19 & 4 & 44 \\
\hline Goulart VII & 1 & - & - & 1 \\
\hline Total & $\mathbf{1 3 0 5}$ & $\mathbf{1 0 9}$ & $\mathbf{4 9}$ & $\mathbf{1 4 6 3}$ \\
\hline
\end{tabular}

*Outros: agrupa os casos em que o procedimento nominal é compulsório, conforme já discutido.

Fonte: Banco de Dados Legis lativos, Cebrap. 
ANEXO I - Saldo das verificações de quorum, por coalizões (1946-1964)*

\begin{tabular}{|l|c|c|c|c|c|c|}
\hline Coalizão & Válidas & Inválidas & $\begin{array}{c}\text { Não } \\
\text { realizadas** }\end{array}$ & Outros*** & $\begin{array}{c}\text { Sem } \\
\text { Informação }\end{array}$ & Total \\
\hline \hline Dutra II & 83 & 171 & 1 & - & - & 255 \\
\hline Dutra III & - & 36 & - & - & - & 36 \\
\hline Vargas I & 9 & 112 & - & - & - & 121 \\
\hline Vargas II & 6 & 145 & 1 & - & - & 152 \\
\hline Vargas III & - & 11 & - & - & - & 11 \\
\hline Café Filho I & 3 & 21 & 76 & 1 & 1 & 102 \\
\hline Café Filho II & 6 & 32 & 18 & 1 & 1 & 58 \\
\hline N. Ramos & 39 & 5 & 18 & - & - & 62 \\
\hline JK I & 111 & 283 & 124 & - & - & 518 \\
\hline JK II & 2 & 184 & 60 & - & 1 & 247 \\
\hline Quadros & 20 & 15 & 2 & - & - & 37 \\
\hline R. Mazzili & 2 & 2 & - & - & - & 4 \\
\hline Goulart I & 1 & 3 & - & - & - & 4 \\
\hline Goulart II & 16 & 37 & 12 & - & - & 65 \\
\hline Goulart III & - & 3 & 3 & - & - & 6 \\
\hline Goulart IV & - & 1 & 3 & - & - & 4 \\
\hline Goulart V & 1 & 6 & - & - & - & 7 \\
\hline Goulart VI & 1 & 17 & 4 & - & - & 22 \\
\hline Goulart VII & - & 1 & - & - & - & 1 \\
\hline Total & 300 & $\mathbf{1 0 8 5}$ & 322 & 2 & 3 & 1712 \\
\hline$(17,5 \%)$ & $(\mathbf{6 3 , 4 \% )}$ & $(18,8 \%)$ & $(0,1 \%)$ & $(0,2 \%)$ & \\
\hline
\end{tabular}

*Desconsidera 17 deliberações nominais "fantasmas", que embora sejam citadas nos Diários da Câmara, não tiveram suas res pectivas listas incorporadas à publicação. **Não realizadas: diz res peito às situações nas quais a checagem de número legal foi dispensada em função da opção do presidente pela chamada nominal direta. ***Outros: corresponde aos casos em que o pedido de verificação de votação foi retirado pelo próprio requerente. 
ANEXO J - Influência da conduta do presidente da Câmara no processo decisório(1946-1964)

\begin{tabular}{|c|c|c|c|c|}
\hline \multirow[b]{2}{*}{ Coalizão } & \multicolumn{3}{|c|}{ Ação do presidente da CD } & \multirow[b]{2}{*}{ Total } \\
\hline & Discricionária & Isenta & $\begin{array}{c}\text { Sem } \\
\text { Informação }\end{array}$ & \\
\hline Dutra II & $171 *$ & 84 & - & 255 \\
\hline Dutra III & 36 & & - & 36 \\
\hline Vargas I & 112 & 9 & - & 121 \\
\hline Vargas II & 145 & 7 & - & 152 \\
\hline Vargas III & 11 & 0 & - & 11 \\
\hline Café Filho I & 21 & 80 & 1 & 102 \\
\hline Café Filho II & 32 & 25 & 1 & 58 \\
\hline N. Ramos & 5 & 57 & - & 62 \\
\hline JK I & 283 & 235 & - & 518 \\
\hline JK II & 184 & 62 & 1 & 247 \\
\hline Quadros & 15 & 22 & - & 37 \\
\hline R. Mazzili & 2 & 2 & - & 4 \\
\hline Goulart I & 3 & 1 & - & 4 \\
\hline Goulart II & 37 & 28 & - & 65 \\
\hline Goulart III & 3 & 3 & - & 6 \\
\hline Goulart IV & 1 & 3 & - & 4 \\
\hline Goulart V & 6 & 1 & - & 7 \\
\hline Goulart VI & 17 & 5 & - & 22 \\
\hline Goulart VII & 1 & & - & 1 \\
\hline Total & $\begin{array}{c}1085 \\
(63,4 \%)\end{array}$ & $\begin{array}{c}624 \\
(36,4 \%)\end{array}$ & $\begin{array}{c}3 \\
(0,2 \%)\end{array}$ & 1712 \\
\hline
\end{tabular}

*Desconsidera 17 deliberações nominais "fantasmas", que embora sejam citadas nos Diários da Câmara, não tiveram suas respectivas listas incorporadas à publicação.

Fonte: Banco de Dados Legis lativos, Cebrap. 


\section{ANEXO K - Resultados estatísticos dos modelos espaciais, por coalizões}

Seguem listadas, abaixo, as saídas do wnominate para os modelos espaciais obtidos a partir da distribuição das votações nominais por coalizões. Até o leitor mais crítico reconhecerá que as mudanças são de pouca monta em relação ao que observamos no exame agregado, por governos.

\section{Comportamento partidário por coalizões}

\section{Dutra II}

$\mathrm{n}=\mathbf{1 3 5}$ nominais

Legisladores-parâmetro: Gustavo Capanema (ID: 160); Janduhy Carneiro (ID: 177)

\section{SUMMARY OF W-NOMINATE OBJECT}

Number of Legislators: 289 (84 legislators deleted)

Number of Votes: $\quad 96$ (39 votes deleted)

Number of Dimensions: 2

Predicted Yeas: $\quad 7128$ of $8379(85.1 \%)$ predictions correct

Predicted Nays: $\quad 6275$ of $7678(81.7 \%)$ predictions correct

Correct Classifiction: $81.6 \% 83.47 \%$

APRE: $\quad 0.3270 .395$

GMP: $\quad 0.6750 .696$

$$
\begin{gathered}
\text { Vargas I } \\
\mathbf{n}=\mathbf{1 3 8} \text { nominais }
\end{gathered}
$$

Legisladores-parâmetro: Gustavo Capanema (ID: 160); Janduhy Carneiro (ID: 177)

\section{SUMMARY OF W-NOMINATE OBJECT}

Number of Legislators: 312 (68 legislators deleted)

Number of Votes: 103 (35 votes deleted)

Number of Dimensions: 2

Predicted Yeas: $\quad 6761$ of $8617(78.5 \%)$ predictions correct

Predicted Nays: $\quad 8913$ of $10770(82.8 \%)$ predictions correct

Correct Classifiction: $\quad 77.68 \% 80.85 \%$
APRE:
0.2610 .366
GMP:
0.6290 .666 


\section{Vargas II \\ $\mathrm{n}=\mathbf{1 5 8}$ nominais}

Legisladores-parâmetro: Gustavo Capanema (ID: 160); Janduhy Carneiro (ID: 177)

\section{SUMMARY OF W-NOMINATE OBJECT}

Number of Legislators: 304 (55 legislators deleted)

Number of Votes: 137 (21 votes deleted)

Number of Dimensions: 2

Predicted Yeas: $\quad 8405$ of $10861(77.4 \%)$ predictions correct

Predicted Nays: $\quad 9820$ of $12086(81.3 \%)$ predictions correct

Correct Classifiction: $\quad 75.76 \% 79.42 \%$

APRE: $\quad 0.190 .313$

GMP: $\quad 0.6090 .643$

\section{Café Filho I \\ $\mathrm{n}=99$ nominais}

Legisladores-parâmetro: Gustavo Capanema (ID: 160); Janduhy Carneiro (ID: 177)

\section{SUMMARY OF W-NOMINATE OBJECT}

Number of Legislators: 225 (111 legislators deleted)

Number of Votes: $\quad 63$ (36 votes deleted)

Number of Dimensions: 2

Predicted Yeas: $\quad 4102$ of $4893(83.8 \%)$ predictions correct

Predicted Nays: $\quad 3423$ of $4288(79.8 \%)$ predictions correct

Correct Classifiction: $\quad 79.57 \% 81.96 \%$
APRE:
GMP:
0.2130 .306
0.6350 .665

\section{Café Filho II \\ $\mathrm{n}=64$ nominais}

Legisladores-parâmetro: Gustavo Capanema (ID: 160); Janduhy Carneiro (ID: 177)

\section{SUMMARY OF W-NOMINATE OBJECT}

Number of Legislators: 260 (121 legislators deleted)

Number of Votes: $\quad 60$ (4 votes deleted)

Number of Dimensions: 2

Predicted Yeas: $\quad 4569$ of $5462(83.7 \%)$ predictions correct

Predicted Nays: $\quad 3268$ of $4433(73.7 \%)$ predictions correct

Correct Classifiction: $74.23 \%$ 79.2\%
APRE:
0.2860 .423

GMP:

0.5980 .642

$$
\begin{gathered}
\text { JK I } \\
\mathbf{n}=421 \text { nominais }
\end{gathered}
$$

Legisladores-parâmetro: Nestor Jost (ID: 449); Janduhy Carneiro (ID: 177)

\section{SUMMARY OF W-NOMINATE OBJECT}

Number of Legislators: 383 (66 legislators deleted) 
Number of Votes: $\quad 325$ (96 votes deleted)

Number of Dimensions: 2

Predicted Yeas: $\quad 24354$ of $29051(83.8 \%)$ predictions correct

Predicted Nays: 20418 of $25537(80 \%)$ predictions correct

Correct Classifiction: $\quad 79.58 \%$ 82.02\%

APRE: $\quad 0.3350 .414$

GMP: $\quad 0.6480 .675$

JK II

$\mathrm{n}=\mathbf{2 2 1}$ nominais

Legisladores-parâmetro: Nestor Jost (ID: 449); Janduhy Carneiro (ID: 177)

SUMMARY OF W-NOMINATE OBJECT

Number of Legislators: 308 (101 legislators deleted)

Number of Votes: 111 (110 votes deleted)

Number of Dimensions: 2

Predicted Yeas: $\quad 7663$ of $9121(84 \%)$ predictions correct

Predicted Nays: $\quad 6331$ of $8021(78.9 \%)$ predictions correct

Correct Classifiction: $\quad 77.87 \% 81.64 \%$

APRE: $\quad 0.2420 .371$

GMP: $\quad 0.6290 .67$

\section{Goulart II \\ $\mathrm{n}=48$ nominais}

Legisladores-parâmetro: Gustavo Capanema (ID: 160); Janduhy Carneiro (ID: 177)

\section{SUMMARY OF W-NOMINATE OBJECT}

Number of Legislators: 185 (195 legislators deleted)

Number of Votes: $\quad 38$ (10 votes deleted)

Number of Dimensions: 2

Predicted Yeas: 2336 of $2725(85.7 \%)$ predictions correct

Predicted Nays: $\quad 1767$ of $2212(79.9 \%)$ predictions correct

Correct Classifiction: $\quad 79.52 \% 83.11 \%$

APRE: $\quad 0.280 .406$

GMP: $\quad 0.6450 .684$ 
Pontos ideais dos deputados por coalizões
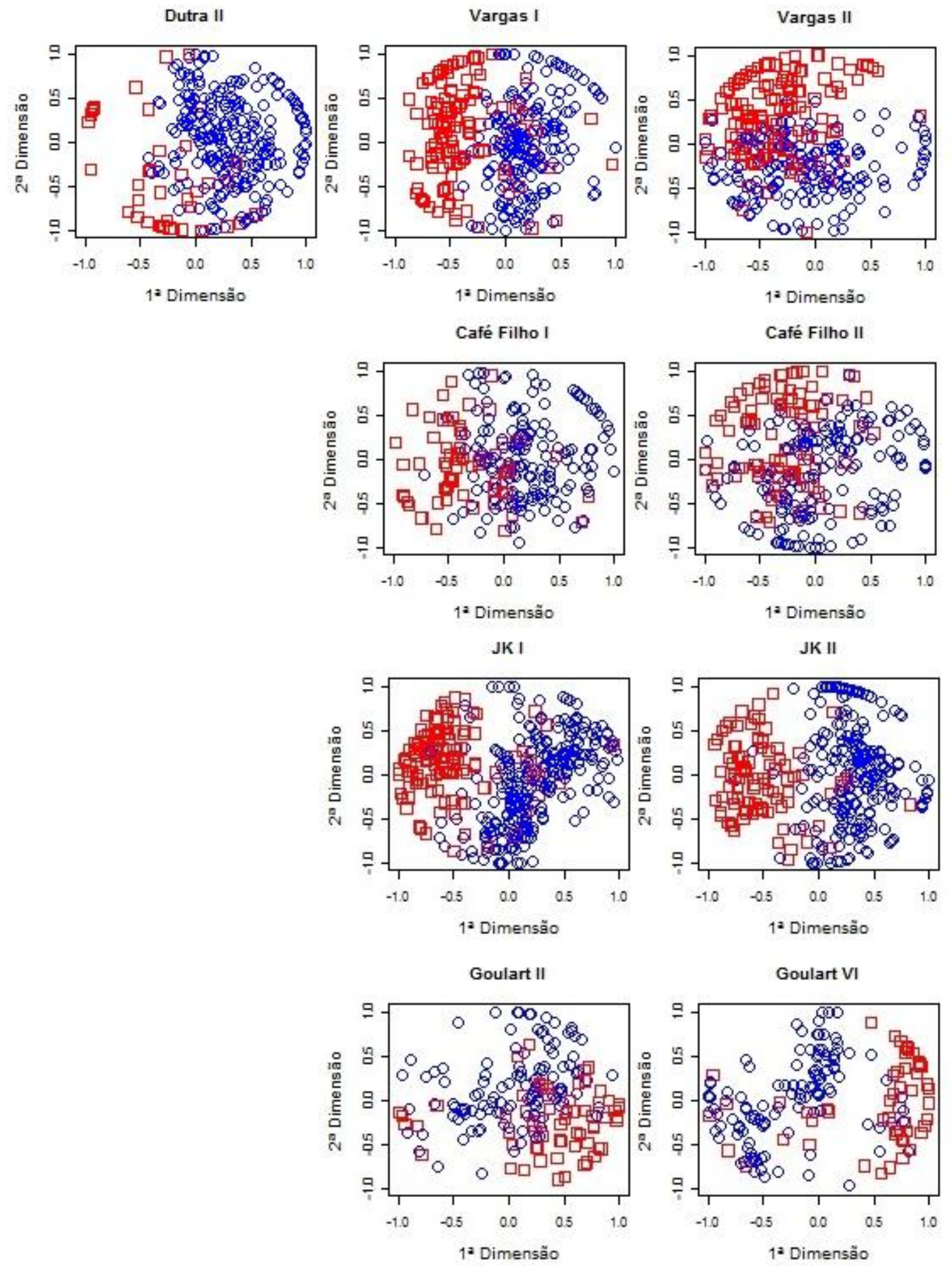
Scree plots por coalizões
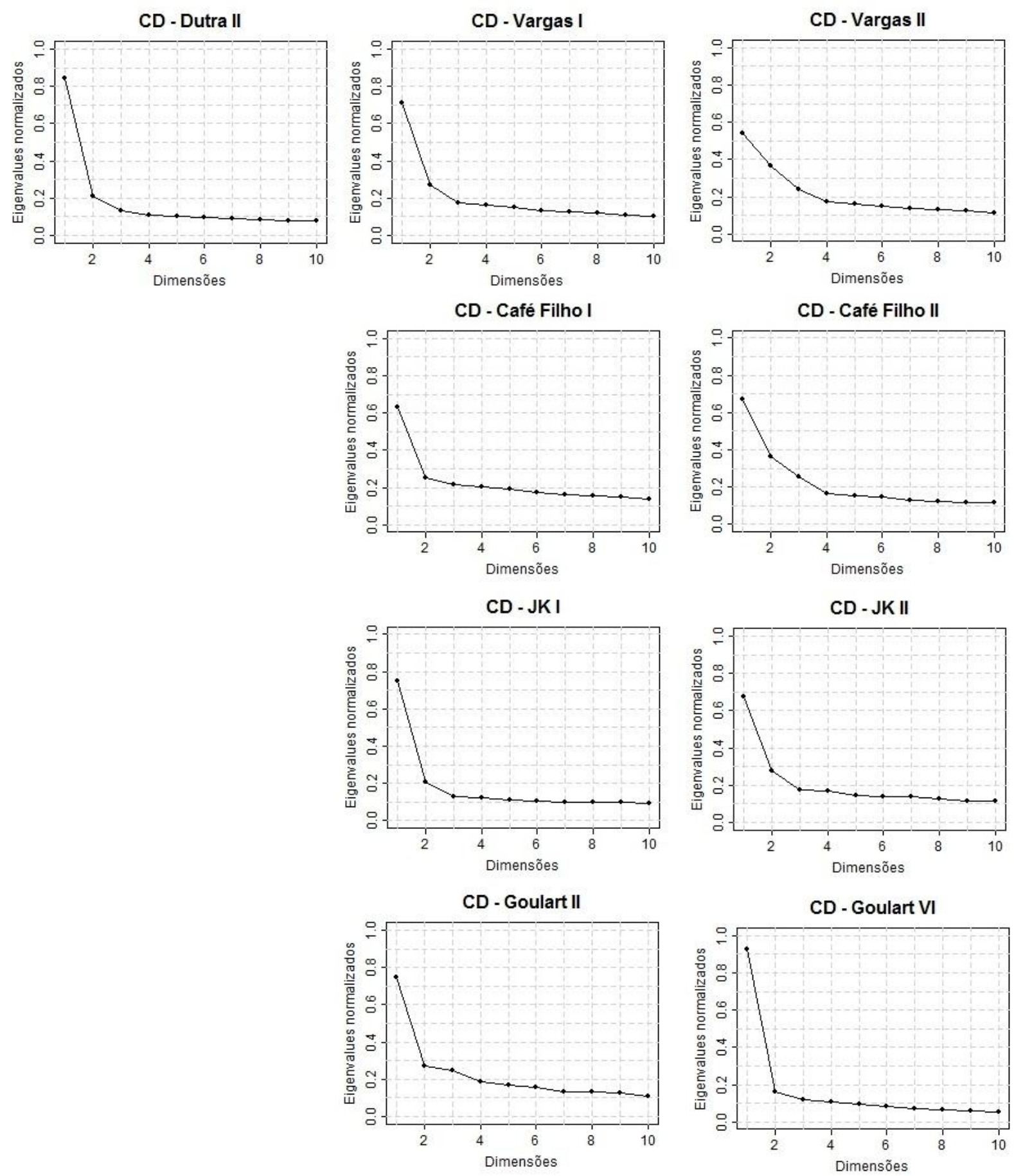


\section{ANEXO L - Temas caros à agenda governamental, objetos de verificação de votação}

É corrente a suspeição de que as ações dos legisladores em plenário se modificassem segundo os interesses políticos do governo envolvidos na apreciação de temas que estivessem sob a orla da sua agenda de trabalho. Para alguns autores, a tese das coalizões ad hoc poderia estar sobredimensionada justamente em função de uma desavisada orientação empírica, considerando-se que muitas votações nominais abarcam questões irrelevantes. Figueiredo e Limongi já alertaram para o fato de que, eventualmente, uma sub-amostra de matérias de interesse do executivo pudesse revelar maior coesão e um padrão de coalizões mais estável durante a democracia populista (FIGUEIREDO, LIMONGI: 1998, p. 20). Para os propósitos da presente pesquisa, isso indicaria a possibilidade da Mesa seguir uma conduta diversa na apreciação de políticas realmente importantes ao Poder Executivo.

Reunir as matérias mais caras às administrações da época, todavia, é tarefa custosa. A maioria dos trabalhos que tratam dessas questões, ora conjunturais, ora perenes, constitui estudos de caso, esmagadoramente voltados aos governos Vargas e Kubitschek, por motivos vários. Nesta perspectiva, a saída para se compilar a lista de temas que gozavam de primazia entre 1946 e 1964 foi adaptar o critério adotado por Mayhew (1991), fundado no reconhecimento dos tópicos como prioritários pela bibliografia especializada. Cada política objeto de votação nominal foi assim classificada se admitida como tal por pelo menos um autor que se dedicou ao exame da democracia populista.

No quadro abaixo está o resultado deste arranjo, que se limitou a sintonizar os registros históricos com as observações empíricas de verificações de votação. Como se vê, políticas sociais são secundárias, predominando questões inerentes ao bom exercício das finanças públicas, sem o controle das quais nenhuma administração se faria promissora. 


\begin{tabular}{|c|c|c|}
\hline Governo & Questão Relevante & Referência \\
\hline \multirow{6}{*}{ Dutra } & Estabelecimento de leis eleitorais & Benevides: $1981 *$ \\
\hline & Extinção de mandatos legislativos & Benevides: $1981 *$ \\
\hline & Revisão de impostos & Consensual** \\
\hline & Reforma administrativa & Consensual** \\
\hline & Reforma dos militares proibidos de propagarem suas doutrinas & Benevides: $1981 *$ \\
\hline & Revisão do regime de licença prévia de importação e exportação com o exterior & Consensual** \\
\hline \multirow{12}{*}{ Vargas } & Acordo Militar com os Estados Unidos & Souza: 1992 \\
\hline & Concessão de benefícios aos militares & Benevides: $1981 *$ \\
\hline & Criação da Pretobras & Hippólito: 1985 \\
\hline & Criação do Banco de Desenvolvimento Econômico & Souza: 1992 \\
\hline & Criação do Banco do Nordeste & Souza: 1992 \\
\hline & Desenho e execução do Fundo de Eletrificação & Souza: 1992 \\
\hline & Desenho e execução do Plano Lafer & Hippólito: 1985 \\
\hline & Desenho e execução do Plano Nacional do Carvão & Souza: 1992 \\
\hline & Instituição do salário mínimo & Souza: 1992 \\
\hline & Reforma administrativa & Consensual** \\
\hline & Regulação da exportação de manganês & Souza: 1992 \\
\hline & Revisão do regime de licença prévia de importação e exportação com o exterior & Consensual** \\
\hline \multirow{7}{*}{$\begin{array}{l}\text { Café } \\
\text { Filho }\end{array}$} & Concessão de benefícios aos militares & Carvalho: $1977 *$ \\
\hline & Criação da Eletrobrás & Carvalho: 1977 \\
\hline & Instituição da cédula oficial nas eleições majoritárias & Benevides: 1981 \\
\hline & Reforma administrativa & Consensual** \\
\hline & Regulamentação de impostos & Consensual $* *$ \\
\hline & Revisão do Código Eleitoral & Benevides: 1981 \\
\hline & Revisão do regime de licença prévia de importação e exportação com o exterior & Consensual** \\
\hline \multirow{12}{*}{ JK } & Aumento salarial do funcionalismo público & Carvalho: 1977 \\
\hline & Autonomia do Distrito Federal & Carvalho: 1977 \\
\hline & Concessão de benefícios aos militares & Carvalho: 1977 \\
\hline & Criação da Eletrobrás & Carvalho: 1977 \\
\hline & Extensão da anistia política & Carvalho: 1977 \\
\hline & Execução do Plano de Reaparelhamento Econômico & Benevides: 1981,Lafer: 2002 \\
\hline & Extensão da legislação trabalhista ao campo & Carvalho: 1977, Camargo: 1981* \\
\hline & Previdência social & Benevides: 1981 \\
\hline & Reforma administrativa & Consensual** \\
\hline & Regulamentação de impostos & Consensual** \\
\hline & Revisão do Código Eleitoral & Benevides: 1981 \\
\hline & Transferência da capital federal para Brasília & Carvalho: 1977 \\
\hline \multirow{3}{*}{ Goulart } & Instituição da cédula oficial nas eleições majoritárias & Benevides: 1981 \\
\hline & Extensão da anistia a presos políticos & Bandeira: $1983 *$ \\
\hline & Reforma agrária & Bandeira: 1983*,Camargo: 1981 \\
\hline
\end{tabular}


*Inferidos a partir do comentário do autor. **Aludidos por todos os autores referidos, ainda que indiretamente.

ANEXO M - Contribuição decisiva dos udenistas nas 17 votações válidas e nãounânimes de iniciativas do Executivo*

\begin{tabular}{|c|c|c|c|c|c|}
\hline \multirow[b]{2}{*}{ Presidente } & \multirow[b]{2}{*}{ Votação** } & \multirow{2}{*}{$\begin{array}{c}\text { Votos } \\
\text { necessários } * * *\end{array}$} & \multicolumn{2}{|c|}{ Contribuições da oposição } & \multirow[b]{2}{*}{ Total } \\
\hline & & & $\begin{array}{c}\text { Votos } \\
\text { udenistas } \\
\end{array}$ & \begin{tabular}{|c|}
$\begin{array}{c}\text { Outros partidos } \\
\text { de oposição }\end{array}$ \\
\end{tabular} & \\
\hline \multirow{2}{*}{ Vargas I } & 1 & 4 & 5 & 12 & 17 \\
\hline & 2 & 15 & 4 & 7 & 11 \\
\hline \multirow{9}{*}{ Vargas II } & 1 & 15 & 19 & 12 & 31 \\
\hline & 2 & 3 & 31 & 24 & 55 \\
\hline & 3 & 5 & 30 & 25 & 55 \\
\hline & 4 & 15 & 29 & 15 & 44 \\
\hline & 5 & 15 & 39 & 12 & 51 \\
\hline & 6 & 20 & 22 & 18 & 40 \\
\hline & 7 & 14 & 9 & 7 & 16 \\
\hline & 8 & 12 & 12 & 7 & 19 \\
\hline & 9 & 3 & 22 & 14 & 36 \\
\hline \multirow{4}{*}{ JK I } & 1 & 2 & 31 & 6 & 37 \\
\hline & 2 & 4 & 38 & 12 & 50 \\
\hline & 3 & 18 & 32 & 8 & 40 \\
\hline & 4 & 10 & 3 & 22 & 25 \\
\hline \multirow{2}{*}{ JK II } & 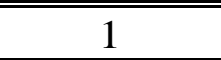 & 17 & $\overline{77}$ & 15 & 22 \\
\hline & 2 & 21 & 3 & 25 & 28 \\
\hline
\end{tabular}

*Inclui apenas votações válidas e não-unânimes de matérias iniciadas pelo Poder Executivo. **Diz respeito à sequência temporal das deliberações em questão. *** Indica a contribuição mínima de votos de oposicionistas que já seria suficiente para que o governo sair vitorioso da votação.

Fonte: Banco de Dados Legis lativos, Cebrap. 
Anexo N - Distribuição das preferências entre os partidos que compõem a coalizão nas 89 votações em que as iniciativas dos governistas só se fizeram aprovadas graças ao apoio da oposição

\begin{tabular}{|c|c|c|c|c|c|c|c|c|c|c|c|c|c|c|c|c|}
\hline \multirow{3}{*}{ Coalizão } & \multirow{3}{*}{ Votação } & \multirow{3}{*}{$\begin{array}{c}\text { No } \\
\text { mínimo } \\
\text { para } \\
\text { vitória }\end{array}$} & \multirow{3}{*}{$\begin{array}{c}\text { Posição } \\
\text { majoritária } \\
\text { do partido do } \\
\text { presidente }\end{array}$} & \multicolumn{8}{|c|}{ Partidos } & \multirow{3}{*}{\begin{tabular}{|c} 
Total de votos \\
disciplinados \\
da base do \\
governo
\end{tabular}} & \multirow{3}{*}{\begin{tabular}{|} 
Total de votos \\
indisciplinados \\
da base do \\
governo
\end{tabular}} & \multirow{3}{*}{$\begin{array}{c}\text { Total de } \\
\text { votos da } \\
\text { base do } \\
\text { governo }\end{array}$} & \multirow{3}{*}{$\begin{array}{c}\text { Votos } \\
\text { faltantes } \\
\text { para o } \\
\text { quorum }\end{array}$} & \multirow{3}{*}{$\begin{array}{c}\text { Total de } \\
\text { contribuições } \\
\text { da oposição }\end{array}$} \\
\hline & & & & \multicolumn{2}{|c|}{ PSD } & \multicolumn{2}{|c|}{ PTB } & \multicolumn{2}{|c|}{ PSP } & \multicolumn{2}{|c|}{ PR } & & & & & \\
\hline & & & & nD* & $\mathbf{n I} * *$ & nD & nI & nD & nI & nD & nI & & & & & \\
\hline \multirow{8}{*}{ Vargas I } & 1 & \multirow{22}{*}{78} & $\mathrm{~N}$ & 47 & 16 & 5 & 25 & 11 & 5 & & & 63 & 46 & 109 & 15 & 47 \\
\hline & 2 & & $\mathrm{~S}$ & 17 & 53 & 33 & 2 & 12 & 5 & & & 62 & 60 & 122 & 16 & 43 \\
\hline & 3 & & $S$ & 44 & 21 & 17 & 6 & 1 & 14 & & & 62 & 41 & 103 & 16 & 29 \\
\hline & 4 & & $\mathrm{~S}$ & 30 & 37 & 26 & 1 & 18 & 3 & & & 74 & 41 & 115 & 4 & 68 \\
\hline & 5 & & $S$ & 31 & 38 & 22 & 11 & 10 & 1 & & & 63 & 50 & 113 & 15 & 68 \\
\hline & 6 & & $\mathrm{~N}$ & 42 & 22 & 10 & 26 & 12 & 5 & & & 64 & 53 & 117 & 14 & 64 \\
\hline & 7 & & $\mathrm{~N}$ & 35 & 35 & 10 & 14 & 12 & 1 & & & 57 & 50 & 107 & 21 & 67 \\
\hline & 8 & & $\mathrm{~N}$ & 41 & 25 & 19 & 4 & 12 & 1 & & & 72 & 30 & 102 & 6 & 50 \\
\hline \multirow{14}{*}{ Vargas II } & 1 & & $S$ & 53 & 7 & 17 & 9 & & & & & 70 & 16 & 86 & 8 & 76 \\
\hline & 2 & & $\mathrm{~N}$ & 59 & 16 & 8 & 32 & & & & & 67 & 48 & 115 & 11 & 63 \\
\hline & 3 & & $\mathrm{~N}$ & 51 & 20 & 14 & 11 & & & & & 65 & 31 & 96 & 13 & 47 \\
\hline & 4 & & $\mathrm{~N}$ & 58 & 12 & 9 & 25 & & & & & 67 & 37 & 104 & 11 & 40 \\
\hline & 5 & & $\mathrm{~N}$ & 50 & 21 & 14 & 20 & & & & & 64 & 41 & 105 & 14 & 37 \\
\hline & 6 & & $\mathrm{~S}$ & 38 & 35 & 26 & 8 & & & & & 64 & 43 & 107 & 14 & 56 \\
\hline & 7 & & $\mathrm{~N}$ & 34 & 30 & 24 & 5 & & & & & 58 & 35 & 93 & 20 & 73 \\
\hline & 8 & & $\mathrm{~S}$ & 45 & 21 & 29 & 6 & & & & & 74 & 27 & 101 & 4 & 71 \\
\hline & 9 & & $\mathrm{~S}$ & 37 & 28 & 31 & 5 & & & & & 68 & 33 & 101 & 10 & 62 \\
\hline & 10 & & $\mathrm{~S}$ & 33 & 29 & 30 & 3 & & & & & 63 & 32 & 95 & 15 & 67 \\
\hline & 11 & & $\mathrm{~N}$ & 38 & 18 & 18 & 13 & & & & & 56 & 31 & 87 & 22 & 48 \\
\hline & 12 & & $\mathrm{~S}$ & 44 & 12 & 21 & 9 & & & & & 65 & 21 & 86 & 13 & 68 \\
\hline & 13 & & $\mathrm{~S}$ & 41 & 23 & 26 & 7 & & & & & 67 & 30 & 97 & 11 & 69 \\
\hline & 14 & & $\mathrm{~S}$ & 35 & 25 & 28 & 8 & & & & & 63 & 33 & 96 & 15 & 57 \\
\hline
\end{tabular}


Anexo N - Distribuição das preferências entre os partidos que compõem a coalizão nas 89 votações em que as iniciativas dos governistas só se fizeram aprovadas graças ao apoio da oposição

\begin{tabular}{|c|c|c|c|c|c|c|c|c|c|c|c|c|c|c|c|c|}
\hline \multirow{3}{*}{ Coalizão } & \multirow{3}{*}{ Votação } & \multirow{3}{*}{$\begin{array}{c}\text { No } \\
\text { mínimo } \\
\text { para } \\
\text { vitória }\end{array}$} & \multirow{3}{*}{$\begin{array}{c}\text { Posição } \\
\text { majoritária } \\
\text { do partido do } \\
\text { presidente }\end{array}$} & \multicolumn{8}{|c|}{ Partidos } & \multirow{3}{*}{\begin{tabular}{|c|} 
Total de votos \\
disciplinados \\
da base do \\
governo
\end{tabular}} & \multirow{3}{*}{\begin{tabular}{|c} 
Total de votos \\
indisciplinados \\
da base do \\
governo
\end{tabular}} & \multirow{3}{*}{$\begin{array}{l}\text { Total de } \\
\text { votos da } \\
\text { base do } \\
\text { governo }\end{array}$} & \multirow{3}{*}{$\begin{array}{c}\text { Votos } \\
\text { faltantes } \\
\text { para o } \\
\text { quorum }\end{array}$} & \multirow{3}{*}{$\begin{array}{c}\text { Total de } \\
\text { contribuições } \\
\text { da oposição }\end{array}$} \\
\hline & & & & \multicolumn{2}{|c|}{ PSD } & \multicolumn{2}{|c|}{ PTB } & \multicolumn{2}{|c|}{ PSP } & \multicolumn{2}{|c|}{ PR } & & & & & \\
\hline & & & & nD* & $\mathbf{n I} * *$ & nD & nI & nD & nI & nD & nI & & & & & \\
\hline \multirow{22}{*}{ Vargas II } & 15 & \multirow{22}{*}{78} & $\mathrm{~N}$ & 48 & 10 & 27 & 5 & & & & & 75 & 15 & 90 & 3 & 55 \\
\hline & 16 & & $\mathrm{~N}$ & 57 & 8 & 14 & 14 & & & & & 71 & 22 & 93 & 7 & 52 \\
\hline & 17 & & $\mathrm{~N}$ & 45 & 15 & 28 & 3 & & & & & 73 & 18 & 91 & 5 & 55 \\
\hline & 18 & & $\mathrm{~N}$ & 47 & 8 & 16 & 12 & & & & & 63 & 20 & 83 & 15 & 44 \\
\hline & 19 & & $S$ & 50 & 15 & 25 & 5 & & & & & 75 & 20 & 95 & 3 & 67 \\
\hline & 20 & & $\mathrm{~S}$ & 32 & 25 & 26 & 5 & & & & & 58 & 30 & 88 & 20 & 56 \\
\hline & 21 & & $\mathrm{~S}$ & 46 & 18 & 25 & 4 & & & & & 71 & 22 & 93 & 7 & 61 \\
\hline & 22 & & $\mathrm{~S}$ & 38 & 30 & 32 & 5 & & & & & 70 & 35 & 105 & 8 & 53 \\
\hline & 23 & & $\mathrm{~S}$ & 38 & 22 & 25 & 3 & & & & & 63 & 25 & 88 & 15 & 57 \\
\hline & 24 & & $\mathrm{~N}$ & 51 & 13 & 14 & 19 & & & & & 65 & 32 & 97 & 13 & 45 \\
\hline & 25 & & $\mathrm{~S}$ & 30 & 29 & 20 & 12 & & & & & 50 & 41 & 91 & 28 & 53 \\
\hline & 26 & & $\mathrm{~N}$ & 51 & 17 & 21 & 14 & & & & & 72 & 31 & 103 & 6 & 60 \\
\hline & 27 & & $\mathrm{~N}$ & 52 & 10 & 9 & 19 & & & & & 61 & 29 & 90 & 17 & 52 \\
\hline & 28 & & $\mathrm{~N}$ & 50 & 12 & 13 & 10 & & & & & 63 & 22 & 85 & 15 & 51 \\
\hline & 29 & & $\mathrm{~N}$ & 46 & 19 & 6 & 19 & & & & & 52 & 38 & 90 & 26 & 46 \\
\hline & 30 & & $\mathrm{~N}$ & 56 & 7 & 10 & 16 & & & & & 66 & 23 & 89 & 12 & 39 \\
\hline & 31 & & $\mathrm{~N}$ & 43 & 16 & 16 & 12 & & & & & 59 & 28 & 87 & 19 & 38 \\
\hline & 32 & & $\mathrm{~S}$ & 52 & 9 & 12 & 13 & & & & & 64 & 22 & 86 & 14 & 36 \\
\hline & 33 & & $\mathrm{~N}$ & 54 & 16 & 23 & 12 & & & & & 77 & 28 & 105 & 1 & 38 \\
\hline & 34 & & $\mathrm{~S}$ & 54 & 7 & 15 & 14 & & & & & 69 & 21 & 90 & 9 & 59 \\
\hline & 35 & & $\mathrm{~S}$ & 41 & 21 & 17 & 9 & & & & & 58 & 30 & 88 & 20 & 28 \\
\hline & 36 & & $\mathrm{~S}$ & 41 & 24 & 22 & 3 & & & & & 63 & 27 & 90 & 15 & 66 \\
\hline
\end{tabular}


Anexo N - Distribuição das preferências entre os partidos que compõem a coalizão nas 89 votações em que as iniciativas dos governistas só se fizeram aprovadas graças ao apoio da oposição

\begin{tabular}{|c|c|c|c|c|c|c|c|c|c|c|c|c|c|c|c|c|}
\hline \multirow{3}{*}{ Coalizão } & \multirow{3}{*}{ Votação } & \multirow{3}{*}{$\begin{array}{c}\text { No } \\
\text { mínimo } \\
\text { para } \\
\text { vitória }\end{array}$} & \multirow{3}{*}{$\begin{array}{c}\text { Posição } \\
\text { majoritária } \\
\text { do partido do } \\
\text { presidente }\end{array}$} & \multicolumn{8}{|c|}{ Partidos } & \multirow{3}{*}{\begin{tabular}{|c} 
Total de votos \\
disciplinados \\
da base do \\
governo
\end{tabular}} & \multirow{3}{*}{\begin{tabular}{|} 
Total de votos \\
indis ciplinados \\
da base do \\
governo
\end{tabular}} & \multirow{3}{*}{$\begin{array}{c}\text { Total de } \\
\text { votos da } \\
\text { base do } \\
\text { governo }\end{array}$} & \multirow{3}{*}{$\begin{array}{c}\text { Votos } \\
\text { faltantes } \\
\text { para o } \\
\text { quorum }\end{array}$} & \multirow{3}{*}{$\begin{array}{c}\text { Total de } \\
\text { contribuições } \\
\text { da oposição }\end{array}$} \\
\hline & & & & \multicolumn{2}{|c|}{ PSD } & \multicolumn{2}{|c|}{ PTB } & \multicolumn{2}{|c|}{ PSP } & \multicolumn{2}{|c|}{ PR } & & & & & \\
\hline & & & & nD* & $\mathbf{n I} * *$ & nD & nI & nD & nI & nD & nI & & & & & \\
\hline \multirow{16}{*}{ Vargas II } & 37 & \multirow{16}{*}{78} & $\overline{N N}$ & 45 & 16 & 13 & 14 & & & & & 58 & 30 & 88 & 20 & 33 \\
\hline & 38 & & $\mathrm{~N}$ & 48 & 9 & 10 & 14 & & & & & 58 & 23 & 81 & 20 & 58 \\
\hline & 39 & & $\mathrm{~N}$ & 55 & 12 & 21 & 1 & & & & & 76 & 13 & 89 & 2 & 57 \\
\hline & 40 & & $\mathrm{~S}$ & 44 & 30 & 16 & 16 & & & & & 60 & 46 & 106 & 18 & 46 \\
\hline & 41 & & $\mathrm{~N}$ & 67 & 2 & 10 & 16 & & & & & 77 & 18 & 95 & 1 & 73 \\
\hline & 42 & & $\mathrm{~N}$ & 56 & 4 & 5 & 18 & & & & & 61 & 22 & 83 & 17 & 58 \\
\hline & 43 & & $\mathrm{~N}$ & 46 & 27 & 19 & 17 & & & & & 65 & 44 & 109 & 13 & 34 \\
\hline & 44 & & $\mathrm{~S}$ & 31 & 37 & 25 & 6 & & & & & 56 & 43 & 99 & 22 & 68 \\
\hline & 45 & & $\mathrm{~S}$ & 33 & 29 & 21 & 8 & & & & & 54 & 37 & 91 & 24 & 58 \\
\hline & 46 & & $\mathrm{~N}$ & 50 & 12 & 14 & 9 & & & & & 64 & 21 & 85 & 14 & 53 \\
\hline & 47 & & $\mathrm{~N}$ & 58 & 4 & 7 & 17 & & & & & 65 & 21 & 86 & 13 & 62 \\
\hline & 48 & & $\mathrm{~S}$ & 43 & 8 & 23 & 8 & & & & & 66 & 16 & 82 & 12 & 56 \\
\hline & 49 & & $\mathrm{~S}$ & 54 & 16 & 21 & 6 & & & & & 75 & 22 & 97 & 3 & 53 \\
\hline & 50 & & $\mathrm{~N}$ & 50 & 7 & 14 & 11 & & & & & 64 & 18 & 82 & 14 & 57 \\
\hline & 51 & & $\mathrm{~N}$ & 52 & 6 & 16 & 12 & & & & & 68 & 18 & 86 & 10 & 17 \\
\hline & 52 & & $\mathrm{~N}$ & 50 & 13 & 6 & 19 & & & & & 56 & 32 & 88 & 22 & 47 \\
\hline \multirow{7}{*}{ JK I } & 1 & \multirow{7}{*}{83} & $\mathrm{~N}$ & 35 & 23 & 33 & 2 & 7 & 7 & 2 & 8 & 77 & 40 & 117 & 6 & 23 \\
\hline & 2 & & $\mathrm{~S}$ & 28 & 38 & 24 & 13 & 18 & 4 & 7 & 2 & 77 & 57 & 134 & 6 & 43 \\
\hline & 3 & & $S$ & 23 & 54 & 25 & 14 & 24 & 0 & 6 & 5 & 78 & 73 & 151 & 5 & 46 \\
\hline & 4 & & $S$ & 27 & 39 & 23 & 9 & 18 & 0 & 5 & 2 & 73 & 50 & 123 & 10 & 43 \\
\hline & 5 & & $\mathrm{~S}$ & 33 & 23 & 15 & 19 & 9 & 9 & 8 & 3 & 65 & 54 & 119 & 18 & 38 \\
\hline & 6 & & $\mathrm{~S}$ & 26 & 27 & 22 & 13 & 14 & 6 & 9 & 1 & 71 & 47 & 118 & 12 & 51 \\
\hline & 7 & & $\mathrm{~N}$ & 43 & 14 & 24 & 17 & 7 & 12 & 7 & 3 & 81 & 46 & 127 & 2 & 15 \\
\hline
\end{tabular}


Anexo N - Distribuição das preferências entre os partidos que compõem a coalizão nas 89 votações em que as iniciativas dos governistas só se fizeram aprovadas graças ao apoio da oposição

\begin{tabular}{|c|c|c|c|c|c|c|c|c|c|c|c|c|c|c|c|c|}
\hline \multirow{3}{*}{ Coalizão } & \multirow{3}{*}{ Votação } & \multirow{3}{*}{$\begin{array}{c}\text { No } \\
\text { mínimo } \\
\text { para } \\
\text { vitória }\end{array}$} & \multirow{3}{*}{$\begin{array}{c}\text { Posição } \\
\text { majoritária } \\
\text { do partido do } \\
\text { presidente }\end{array}$} & \multicolumn{8}{|c|}{ Partidos } & \multirow{3}{*}{\begin{tabular}{|c|} 
Total de votos \\
disciplinados \\
da base do \\
governo
\end{tabular}} & \multirow{3}{*}{\begin{tabular}{|c} 
Total de votos \\
indisciplinados \\
da base do \\
governo
\end{tabular}} & \multirow{3}{*}{\begin{tabular}{|l} 
Total de \\
votos da \\
base do \\
governo
\end{tabular}} & \multirow{3}{*}{\begin{tabular}{|} 
Votos \\
faltantes \\
para o \\
quorum
\end{tabular}} & \multirow{3}{*}{$\begin{array}{c}\text { Total de } \\
\text { contribuições } \\
\text { da oposição }\end{array}$} \\
\hline & & & & \multicolumn{2}{|c|}{ PSD } & \multicolumn{2}{|c|}{ PTB } & \multicolumn{2}{|c|}{ PSP } & \multicolumn{2}{|c|}{ PR } & & & & & \\
\hline & & & & nD* & $\mathbf{n I} * *$ & nD & nI & nD & nI & nD & nI & & & & & \\
\hline \multirow{10}{*}{ JK I } & 8 & \multirow{20}{*}{83} & $\mathrm{~N}$ & 43 & 18 & 2 & 34 & 10 & 7 & 10 & 5 & 65 & 64 & 129 & 18 & 46 \\
\hline & 9 & & $\mathrm{~N}$ & 58 & 11 & 7 & 28 & 7 & 10 & 9 & 5 & 81 & 54 & 135 & 2 & 15 \\
\hline & 10 & & $\mathrm{~N}$ & 50 & 6 & 15 & 14 & 11 & 8 & 3 & 5 & 79 & 33 & 112 & 4 & 22 \\
\hline & 11 & & $N$ & 47 & 12 & 22 & 14 & 5 & 14 & 4 & 4 & 78 & 44 & 122 & 5 & 39 \\
\hline & 12 & & $\mathrm{~N}$ & 56 & 12 & 5 & 22 & 14 & 5 & 5 & 5 & 80 & 44 & 124 & 3 & 24 \\
\hline & 13 & & $S$ & 12 & 43 & 27 & 3 & 12 & 4 & 5 & 4 & 56 & 54 & 110 & 27 & 51 \\
\hline & 14 & & $S$ & 35 & 20 & 24 & 7 & 11 & 2 & 7 & 3 & 77 & 32 & 109 & 6 & 54 \\
\hline & 15 & & $\mathrm{~N}$ & 47 & 18 & 7 & 34 & 16 & 2 & 8 & 2 & 78 & 56 & 134 & 5 & 41 \\
\hline & 16 & & $S$ & 51 & 11 & 19 & 18 & 6 & 4 & 5 & 2 & 81 & 35 & 116 & 2 & 26 \\
\hline & 17 & & $\mathrm{~N}$ & 44 & 11 & 20 & 16 & 8 & 3 & 7 & 0 & 79 & 30 & 109 & 4 & 50 \\
\hline \multirow{10}{*}{ JK I } & 1 & & $\mathrm{~N}$ & 38 & 21 & 21 & 21 & 4 & 5 & 2 & 4 & 65 & 51 & 116 & 18 & 40 \\
\hline & 2 & & $\mathrm{~N}$ & 44 & 20 & 16 & 15 & 2 & 8 & 5 & 1 & 67 & 44 & 111 & 16 & 25 \\
\hline & 3 & & $S$ & 41 & 9 & 20 & 18 & 10 & 2 & 2 & 1 & 73 & 30 & 103 & 10 & 52 \\
\hline & 4 & & $\mathrm{~N}$ & 48 & 12 & 12 & 21 & 6 & 10 & 5 & 6 & 71 & 49 & 120 & 12 & 23 \\
\hline & 5 & & $\mathrm{~N}$ & 46 & 2 & 2 & 30 & 13 & 2 & 5 & 4 & 66 & 38 & 104 & 17 & 45 \\
\hline & 6 & & $\mathrm{~S}$ & 33 & 35 & 26 & 5 & 12 & 7 & 8 & 5 & 79 & 52 & 131 & 4 & 64 \\
\hline & 7 & & $\mathrm{~S}$ & 22 & 32 & 23 & 10 & 15 & 3 & 2 & 5 & 62 & 50 & 112 & 21 & 27 \\
\hline & 8 & & $S$ & 31 & 27 & 27 & 11 & 13 & 4 & 9 & 3 & 80 & 45 & 125 & 3 & 42 \\
\hline & 9 & & $S$ & 48 & 12 & 4 & 34 & 7 & 6 & 7 & 4 & 66 & 56 & 122 & 17 & 39 \\
\hline & 10 & & $S$ & 41 & 20 & 23 & 17 & 11 & 2 & 2 & 7 & 77 & 46 & 123 & 6 & 15 \\
\hline
\end{tabular}


ANEXO O - Contribuição decisiva dos udenistas nas 89 votações válidas e não- unânimes iniciadas pelo governo*

\begin{tabular}{|c|c|c|c|c|c|}
\hline \multirow[b]{2}{*}{ Presidente } & \multirow[b]{2}{*}{ Votação** } & \multirow[b]{2}{*}{$\begin{array}{c}\text { Votos } \\
\text { necessários } * * *\end{array}$} & \multicolumn{2}{|c|}{ Contribuições da oposição } & \multirow[b]{2}{*}{ Total } \\
\hline & & & $\begin{array}{c}\text { Votos } \\
\text { udenistas }\end{array}$ & $\begin{array}{c}\text { Outros partidos } \\
\text { de oposição }\end{array}$ & \\
\hline \multirow{8}{*}{ Vargas I } & 1 & 15 & 31 & 16 & 47 \\
\hline & 2 & 16 & 31 & 12 & 43 \\
\hline & 3 & 16 & 22 & 22 & 44 \\
\hline & 4 & 4 & 54 & 14 & 68 \\
\hline & 5 & 15 & 48 & 20 & 68 \\
\hline & 6 & 14 & 48 & 16 & 64 \\
\hline & 7 & 21 & 53 & 14 & 67 \\
\hline & 8 & 6 & 37 & 13 & 50 \\
\hline \multirow{30}{*}{ Vargas II } & 1 & 8 & 47 & 29 & 76 \\
\hline & 2 & 11 & 36 & 27 & 63 \\
\hline & 3 & 13 & 33 & 14 & 47 \\
\hline & 4 & 11 & 26 & 14 & 40 \\
\hline & 5 & 14 & 24 & 13 & 37 \\
\hline & 6 & 14 & 30 & 26 & 56 \\
\hline & 7 & 20 & 44 & 29 & 73 \\
\hline & 8 & 4 & 44 & 27 & 71 \\
\hline & 9 & 10 & 37 & 25 & 62 \\
\hline & 10 & 15 & 35 & 32 & 67 \\
\hline & 11 & 22 & 31 & 17 & 48 \\
\hline & 12 & 13 & 39 & 29 & 68 \\
\hline & 13 & 11 & 40 & 29 & 69 \\
\hline & 14 & 15 & 33 & 24 & 57 \\
\hline & 15 & 3 & 31 & 24 & 55 \\
\hline & 16 & 7 & 35 & 17 & 52 \\
\hline & 17 & 5 & 30 & 25 & 55 \\
\hline & 18 & 15 & 29 & 15 & 44 \\
\hline & 19 & 3 & 42 & 25 & 67 \\
\hline & 20 & 20 & 32 & 24 & 56 \\
\hline & 21 & 7 & 32 & 29 & 61 \\
\hline & 22 & 8 & 23 & 30 & 53 \\
\hline & 23 & 15 & 32 & 25 & 57 \\
\hline & 24 & 13 & 33 & 12 & 45 \\
\hline & 25 & 28 & 27 & 26 & 53 \\
\hline & 26 & 6 & 44 & 16 & 60 \\
\hline & 27 & 17 & 39 & 13 & 52 \\
\hline & 28 & 15 & 39 & 12 & 51 \\
\hline & 29 & 26 & 30 & 16 & 46 \\
\hline & 30 & 12 & 20 & 19 & 39 \\
\hline
\end{tabular}

Continua... 
ANEXO O - Contribuição decisiva dos udenistas nas 89 votações válidas e não- unânimes iniciadas pelo governo*

\begin{tabular}{|c|c|c|c|c|c|}
\hline \multirow[b]{2}{*}{ Presidente } & \multirow[b]{2}{*}{ Votação** } & \multirow{2}{*}{$\begin{array}{c}\text { Votos } \\
\text { necessários } * * *\end{array}$} & \multicolumn{2}{|c|}{ Contribuições da oposição } & \multirow[b]{2}{*}{ Total } \\
\hline & & & $\begin{array}{c}\text { Votos } \\
\text { udenistas }\end{array}$ & $\begin{array}{l}\text { Outros partidos } \\
\text { de oposição }\end{array}$ & \\
\hline \multirow{22}{*}{ Vargas II } & 31 & 19 & 30 & 8 & 38 \\
\hline & 32 & 14 & 23 & 13 & 36 \\
\hline & 33 & 1 & 21 & 17 & 38 \\
\hline & 34 & 9 & 39 & 20 & 59 \\
\hline & 35 & 20 & 21 & 7 & 28 \\
\hline & 36 & 15 & 40 & 26 & 66 \\
\hline & 37 & 20 & 18 & 15 & 33 \\
\hline & 38 & 20 & 34 & 24 & 58 \\
\hline & 39 & 2 & 34 & 23 & 57 \\
\hline & 40 & 18 & 23 & 23 & 46 \\
\hline & 41 & 1 & 52 & 21 & 73 \\
\hline & 42 & 17 & 40 & 18 & 58 \\
\hline & 43 & 13 & 23 & 11 & 34 \\
\hline & 44 & 22 & 32 & 36 & 68 \\
\hline & 45 & 24 & 27 & 31 & 58 \\
\hline & 46 & 14 & 37 & 16 & 53 \\
\hline & 47 & 13 & 40 & 22 & 62 \\
\hline & 48 & 12 & 31 & 25 & 56 \\
\hline & 49 & 3 & 30 & 23 & 53 \\
\hline & 50 & 14 & 30 & 27 & 57 \\
\hline & 51 & 10 & 6 & 11 & 17 \\
\hline & 52 & 22 & 33 & 14 & 47 \\
\hline \multirow{15}{*}{ JK I } & 1 & 6 & 11 & 12 & 23 \\
\hline & 2 & 6 & 31 & 12 & 43 \\
\hline & 3 & 5 & 32 & 14 & 46 \\
\hline & 4 & 10 & 32 & 11 & 43 \\
\hline & 5 & 18 & 24 & 14 & 38 \\
\hline & 6 & 12 & 37 & 14 & 51 \\
\hline & 7 & 2 & 8 & 7 & 15 \\
\hline & 8 & 18 & 35 & 11 & 46 \\
\hline & 9 & 2 & 10 & 5 & 15 \\
\hline & 10 & 4 & 15 & 7 & 22 \\
\hline & 11 & 5 & 33 & 6 & 39 \\
\hline & 12 & 3 & 13 & 11 & 24 \\
\hline & 13 & 27 & 40 & 11 & 51 \\
\hline & 14 & 6 & 40 & 14 & 54 \\
\hline & 15 & 5 & 31 & 10 & 41 \\
\hline
\end{tabular}


ANEXO O - Contribuição decisiva dos udenistas nas 89 votações válidas e não- unânimes iniciadas pelo governo*

\begin{tabular}{|c|c|c|c|c|c|}
\hline \multirow[b]{2}{*}{ Presidente } & \multirow[b]{2}{*}{ Votação** } & \multirow[b]{2}{*}{$\begin{array}{c}\text { Votos } \\
\text { necessários } * * *\end{array}$} & \multicolumn{2}{|c|}{ Contribuições da oposição } & \multirow[b]{2}{*}{ Total } \\
\hline & & & $\begin{array}{c}\text { Votos } \\
\text { udenistas }\end{array}$ & $\begin{array}{c}\text { Outros partidos } \\
\text { de oposição }\end{array}$ & \\
\hline \multirow{5}{*}{ JK I } & 16 & 2 & 22 & 4 & 26 \\
\hline & 17 & 4 & 38 & 12 & 50 \\
\hline & 18 & 18 & 32 & 8 & 40 \\
\hline & 19 & 16 & 21 & 4 & 25 \\
\hline & 20 & 10 & 46 & 6 & 52 \\
\hline \multirow{7}{*}{ JK II } & 1 & 12 & 20 & 3 & 23 \\
\hline & 2 & 17 & 30 & 15 & 45 \\
\hline & 3 & 4 & 33 & 31 & 64 \\
\hline & 4 & 21 & 17 & 10 & 27 \\
\hline & 5 & 3 & 27 & 15 & 42 \\
\hline & 6 & 17 & 30 & 9 & 39 \\
\hline & 7 & 6 & 9 & 34 & 43 \\
\hline \multirow{2}{*}{ Goulart VI } & 1 & 19 & 32 & 20 & 52 \\
\hline & 2 & 13 & 38 & 13 & 51 \\
\hline
\end{tabular}

*Inclui apenas votações válidas e não-unânimes de matérias iniciadas pelo Poder Executivo. **Diz respeito à sequência temporal das deliberações em questão. *** Indica a contribuição mínima de votos de oposicionis tas que já seria suficiente para que o governo sair vitorioso da votação.

Fonte: Banco de Dados Legislativos, Cebrap.

\section{Conclusão}

